\title{
Smaller molluscs from a multi-taxon survey (2012-2014) of the shallow marine environments of the tropical Kimberley region, Western Australia
}

\author{
Peter Middelfart*, Lisa Kirkendale and Clay Bryce
}

Aquatic Zoology Department, Western Australia Museum, Locked Bag 49, Welshpool DC, Western Australia, Australia

* Corresponding author: petermiddelfart@hotmail.com

\begin{abstract}
The marine environments of Western Australia's Kimberley region (coast to continental edge) are rich in spatial diversity and vast in scale affording a broad range of habitats for marine fauna and flora. The macromolluscan (here defined as adult molluscs $>10 \mathrm{~mm}$ ) diversity of this large marine realm has been the subject of numerous surveys over the last 50 years. However, the smaller molluscs (here defined as adult molluscs $<10 \mathrm{~mm}$ ) have, for the most part, been ignored due to challenges in the collection and study of this assemblage. To begin to redress this imbalance a pilot project specifically designed to target smaller molluscs was undertaken over the final three years (2012-2014) of the survey component of the Woodside Collection Project (Kimberley) 2009-2014. Seventy-seven stations (of 179 surveyed) were sampled yielding 1,883 identified specimen lots representing 505 micromollusc species from $\leq 5 \mathrm{~mm}$ adult size class (following Geiger et al. 2007), 43 species from $>5-10 \mathrm{~mm}$ adult size class, 68 species from $>10 \mathrm{~mm}$ adult size class, which are likely to be juveniles of macromolluscs, as well as 8 species whose adult size could not be determined. This diversity spans 102 family or superfamily level taxa. Twenty-one of these familial level taxa were new to the survey area (see Bryce et al. 2018 for a full description of the Kimberley survey area) and the number of taxa recorded from a further 18 families was doubled. A considerable degree of species rarity characterised this fauna with almost $52 \%$ of all species being singletons. Less than $22 \%$ of taxa were recorded from three or more stations. A total of at least 26 new species, not yet formally described, as well as an additional 23 new records, for the survey area and/or Australia were discovered, yielding 49 new species-level records. Two formal taxonomic revisions are undertaken in this paper due to the acquisition of new material and a review of type material. Firstly, Haplocochlias minutissumus Pilsbry, 1921 is synonymised under Liotina parvissima Hedley, 1899 [as Lophocochlias parvissimus (Hedley, 1899)]. Secondly, the synonymy of Condylocuna io (Bernard, 1915) and Condylocuna tricosa Middelfart, 2002, is revoked. Many putative species require further study to determine their taxonomic status; several are probably new to science.
\end{abstract}

KEYWORDS: biodiversity, Indian Ocean, Kimberley survey area, smaller molluscs, micromolluscs, northwest Australia, Woodside Collection Project

\section{INTRODUCTION}

The Kimberley marine region is a remote part of northern Australia with a high degree of habitat complexity. It is vast in area and it extends from the coast to the edge of the continental shelf. The coast is characterised by large river systems, expansive estuaries, and coral, rock, sand and mud habitats. The wide continental shelf extends offshore to a series of mid-shelf reefs and shelf-edge atolls with well-developed coral reefs adjacent to deep-sea basins (Sampey et al. 2014). While some studies have been undertaken of the region's biota (see
Wells and Allen 2005; Wilson 2014; Kirkendale et al. 2019), baseline marine research is still necessary to generate core information suitable for the management of the region's conservation, tourist and industrial potential (Kirkendale et al. 2019). One of the largest projects to document marine biodiversity of the region, indeed any region within Australia, was The Woodside Collection Project (Kimberley) 2008-2015 (see Sampey et al. (2014) for a full description of the Project Area and historical collections and Bryce et al. (2018) for survey area and methodology information). 
With 179 stations surveyed (Bryce et al. 2018), the documentation of the molluscs fauna from the Kimberley survey area has been separated into three parts. The published historical dataset documenting the museum-archived molluscan diversity for the region was completed in 2015 (Willan et al. 2015), which reported on 1,784 species. A publication documenting macromollusc ( $>10 \mathrm{~mm}$ when adult) results is in preparation (Kirkendale et al. in prep.) and this present paper focuses on the outcomes of a pilot project specifically designed to capture and assess smaller molluscan $(<10 \mathrm{~mm}$ when adult) diversity in the region.

Smaller molluscs (i.e., molluscs $<10 \mathrm{~mm}$ in greatest shell dimension) constitute a key element in marine ecosystems and often occur in abundance and great diversity (Albano et al. 2011; Middelfart et al. 2016). Their lifestyles are varied and include grazing assemblages (e.g. Rissooidea), a predatory component (e.g. Conoidea), parasites (e.g. Pyramidelloidea) and commensals (e.g. Galeommatoidea) (Beesley et al. 1998; Morton 1988). In soft boreal sediments, microbivalves (e.g. Mysella) and microgastropods (e.g. Rissooidea) may exhibit densities numbering thousands per square metre (Muus 1967; Ockelmann and Muus 1978; Middelfart pers. obs.). By comparison, tropical reefs systems tend to host high diversity and low abundance across most microgastropod taxa (Bouchet et al. 2002; Barnes 2019). Smaller molluscs are an important food source for benthic predators and are important grazers and bioturbators of sediments (Mann 1982).

A lack of elementary identification resources has, in part, resulted in the exclusion of smaller molluscs from marine faunal surveys undertaken in Western Australia (WA), and to some extent nationally and globally. Moreover, identification of smaller molluscs requires a large time commitment to access the scattered literature contained in library databases. While numerous published works are available to identify Australian macromolluscs, the literature on smaller molluscs is patchy and, in many instances, outdated. Often the original publication, dating back several decades, is the only information available. Access to older literature has been improved with the creation and public availability of the Biodiversity Heritage Library. However, illustrations and detailed descriptions of microscopic species are often poor, missing or incomplete leading to identification uncertainty. A number of revisions have been published, which clarify the limitations of earlier works and enable identification of some groups (Ponder and Yoo 1981; Marshall 1983, 1988; Ponder 1985, 1990; Dijkstra 1991; Middelfart 2002a, b; Renard and Bouchet 2003; Cossignani 2006; Dijkstra and Maestrati 2008; Geiger 2012; Pizzini et al. 2013; Warén 2013).
Collecting smaller molluscs is logistically complicated due to their size (Middelfart et al. 2016), but scrubbing rocks and rock walls, the use of suction pumps, elutriation of sea water following shaking and scrubbing of seaweed and rocks, and sieving sediments are wellestablished methods (Geiger et al. 2007). Visual detection is an additional challenge. While many smaller molluscs range upward from $3 \mathrm{~mm}$ in length and are just observable with the naked eye, many are only a few hundred micrometres long and therefore require the use of highpowered microscopes to observe and illustrate the most delicate shell features on these tiny specimens, Consequently, Scanning Electron Microscopy (SEM) is the only option. Image stacking methodologies and high-resolution digital cameras are also important tools that can produce specimen images in $<1 \mathrm{~mm}$ category (Geiger et al. 2007).

Early taxonomic works on smaller molluscs from the tropical coast of northern Australia includes those by Hedley (1918); Laseron (1956a,b, 1958a,b, 1959) and Iredale and Laseron (1957). Many of these studies included micromolluscs collected from throughout Australia (Ponder and Yoo 1977, 1978; Ponder 1983, 1985, 1990, 1999; Ponder and de Keyzer 1992; Middelfart 2002a,b). Interest in the Australian temperate coast was fuelled by the numerous endemic taxa discovered there (Marshall 1983). The publications listed by Wells and Allen (2005) and by Willan (2005, 2015), which include specimens collected in the Kimberley Project Area (Sampey et al. 2014 for project area boundaries), include some smaller molluscs. Important international publications are the revision of the Scissurellidae (Geiger 2012) and Marine Mollusks in Japan by Okutani (2017).

Recent studies have revealed that smaller molluscs represent a substantial component of worldwide diversity and, once integrated into inventories, increase biodiversity estimates by orders of magnitude (Bouchet et al. 2002; Albano et al. 2011; Middelfart et al. 2016). This component of biodiversity has been inadequately characterised, but it is likely to be very species rich in regions of complex spatial and temporal heterogeneity, such as the marine bioregions of the Kimberley (Wilson 2014).

\section{AIMS}

The aim of this study was to test semiquantitative field collection methods to assess diversity of smaller molluscs in the Kimberley Project Area. The approach was threefold: 
1. To sample habitats harbouring potential smaller molluscs from 77 stations in the survey area.

2. To produce a smaller-mollusc inventory for the region.

3. To report on morphospecies diversity.

\section{METHODS}

The sampling program to collect smaller molluscs was undertaken from 2012-2014 as an adjunct to a macromollusc survey for the Woodside Collection Project (Kimberley) 2008-2015, during which on-site surveys were carried out from 2009-2014 (Bryce et al. 2018). During the earlier 2009-2011 survey period, sediments were retained as a by-product of sampling other taxa, e.g. during rock breaking for polychaetes and small crustaceans. These sediments were sorted as part of the smallermollusc study to extend the sampling to other habitats, as well as to stations not covered in 20132014. The surveyed stations chosen in 2013-2014 had suitable habitat for rock scrubbing in an allowable timeframe They were geographically categorised following Richards et al. (2018) (see Table 2).

The smallest size category of molluscs retrieved (i.e. $\leq 5 \mathrm{~mm}$ adult size class) was classified as micromolluscs (M), following Geiger et al. (2007). Recognition of this fraction is important as it permits comparison with recent published literature. A slightly larger category of $>5-10 \mathrm{~mm}$ adult size (Me) was also sorted and tallied. While not formally treated by previous authors, it is recognised here because it represents a neglected component of molluscan diversity that has not previously been studied in Western Australia. Additionally, many superfamilies include species that span adult sizes e.g. 1-10 $\mathrm{mm}$ in the Truncatelloidea and Pyramidelloidea and the micromollusc size class splits these superfamilies arbitrarily. Consequently we include this larger size category to begin to address this issue. Juvenile molluscs with an adult size $>10 \mathrm{~mm}$ (Ma) were tallied as the third size category.

These were included because, similar to the $>5-10 \mathrm{~mm}$ adult size class referred to earlier, they represent diversity often overlooked. However, they can be crucial for insights into little known, yet taxonomically informative life-history stages, which may highlight cryptic species (pers. comm. K. Ockelmann).

The smaller-mollusc sampling program was an addition to the already existing macromollusc survey and methods were developed to minimise additional survey time and effort. Four collecting bags were designed and constructed to retain sediment while allowing water to drain. The collectors (C. Bryce and L. Kirkendale), separated by at least $50 \mathrm{~m}$ as defined by the transect survey tape would identify a rock or rubble site. A visually estimated 10 litre volume of rocks or rubble was then scrubbed with a laundry brush into the collecting bags. On deck, the brushed sediment from each bag was combined and run through a series of sieves to $250 \mu \mathrm{m}$ mesh size. Any macromolluscs (Ma) over $10 \mathrm{~mm}$ were removed by hand. The post-sieved sediment was preserved in $100 \%$ ethanol for further processing at the Western Australian Museum (WAM).

In the laboratory at the WAM, samples from 77 stations were processed using two or more techniques (Table 1) for smaller molluscs (live and dead collected specimens). Each subsample was spread thinly in a $120 \mathrm{~mm}$ petri dish and all molluscs (i.e. M, Ma and Me size categories) were sorted using forceps and fine brushes. Because of the potential scale of the project, the volume subsampled from each station was calibrated until a workable smaller volume was achieved (Table 1).

The fauna encountered in this study was characterised by a morphospecies concept or Operational Taxonomic Unit (OTU) where a 'normal' adult specimen or specimen lot, representing a species, was chosen as the morphotype for that taxon. That specimen/lot became the reference for all future identifications of that particular taxon. Every subsequent observed shell was compared to the pool of OTUs and matched or provided with a new OTU and photographed. The morphospecies concept was utilised as a practical approach to characterise high diversity, with species identification undertaken where possible. Middelfart $(2002 \mathrm{a}, \mathrm{b})$ used this method on the microbivalve groups, Condylocardiinae and Cuninae. The technique relies on the ability of the taxonomist to differentiate species, with less focus on taxonomic identification, which can be time consuming and reliant on the taxonomic expertise of the researcher. This rationale is similar to barcoding, which involves sequencing a quickly evolving gene region (such as COI or COX1) for species comparison, but with different strengths and weaknesses. For example, cryptic species are likely to be lumped into one species, but the involvement of a taxonomist may offer the additional benefit of a full species identification.

Taxa were identified to species or morphospecies as defined above. Systematic placement and current name assignments were checked against WoRMS (World Register of Marine Species), the AFD (Australian Faunal Directory) and the ALA (Atlas of Living Australia) to reach a consensus as at 1 March 2018, with WoRMS the ultimate arbiter. Taxonomic experts were contacted for assistance with problematic groups (Dan Geiger, Scissurellidae and Winston Ponder, Eatoniellidae, Rissoellidae, 


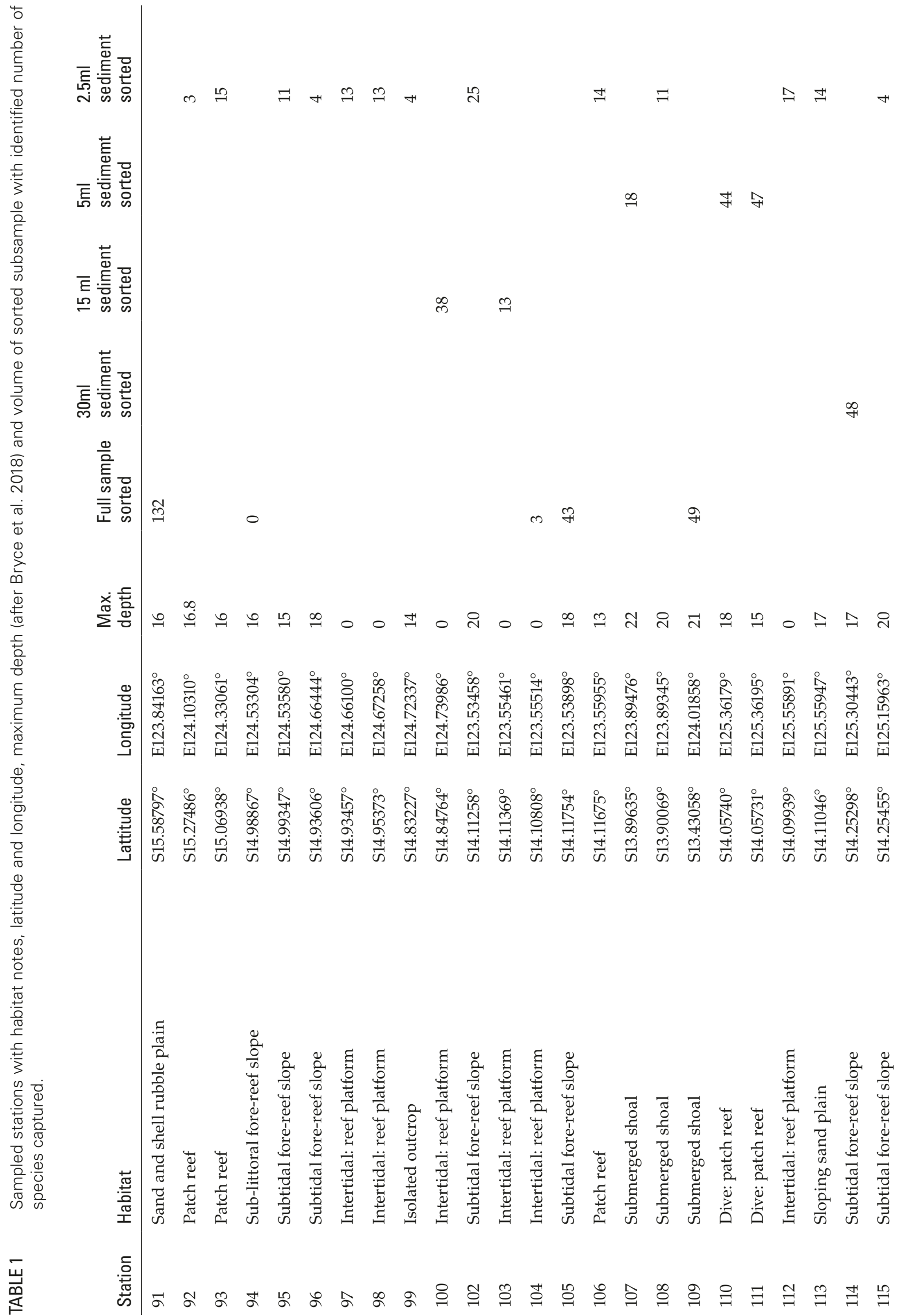




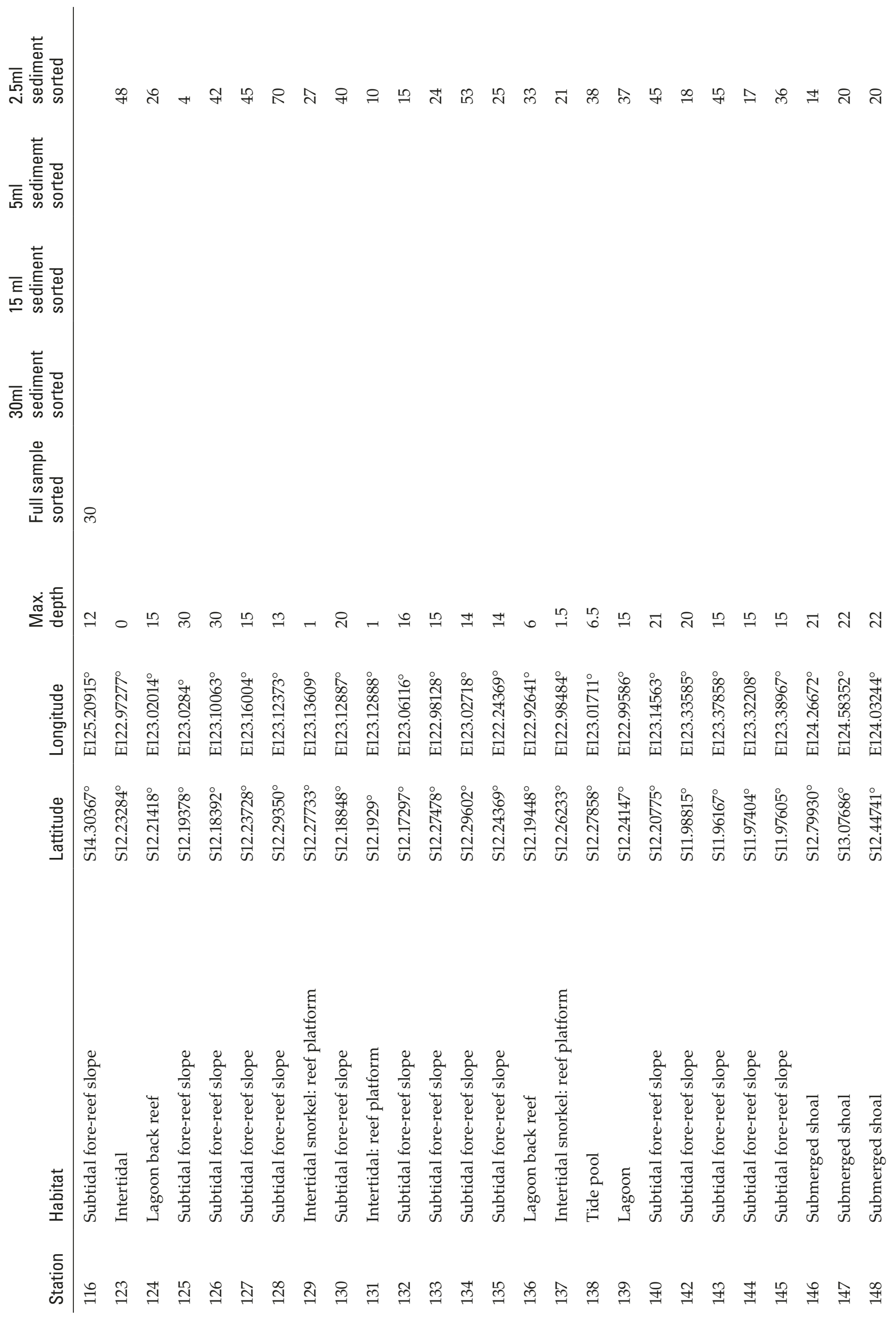




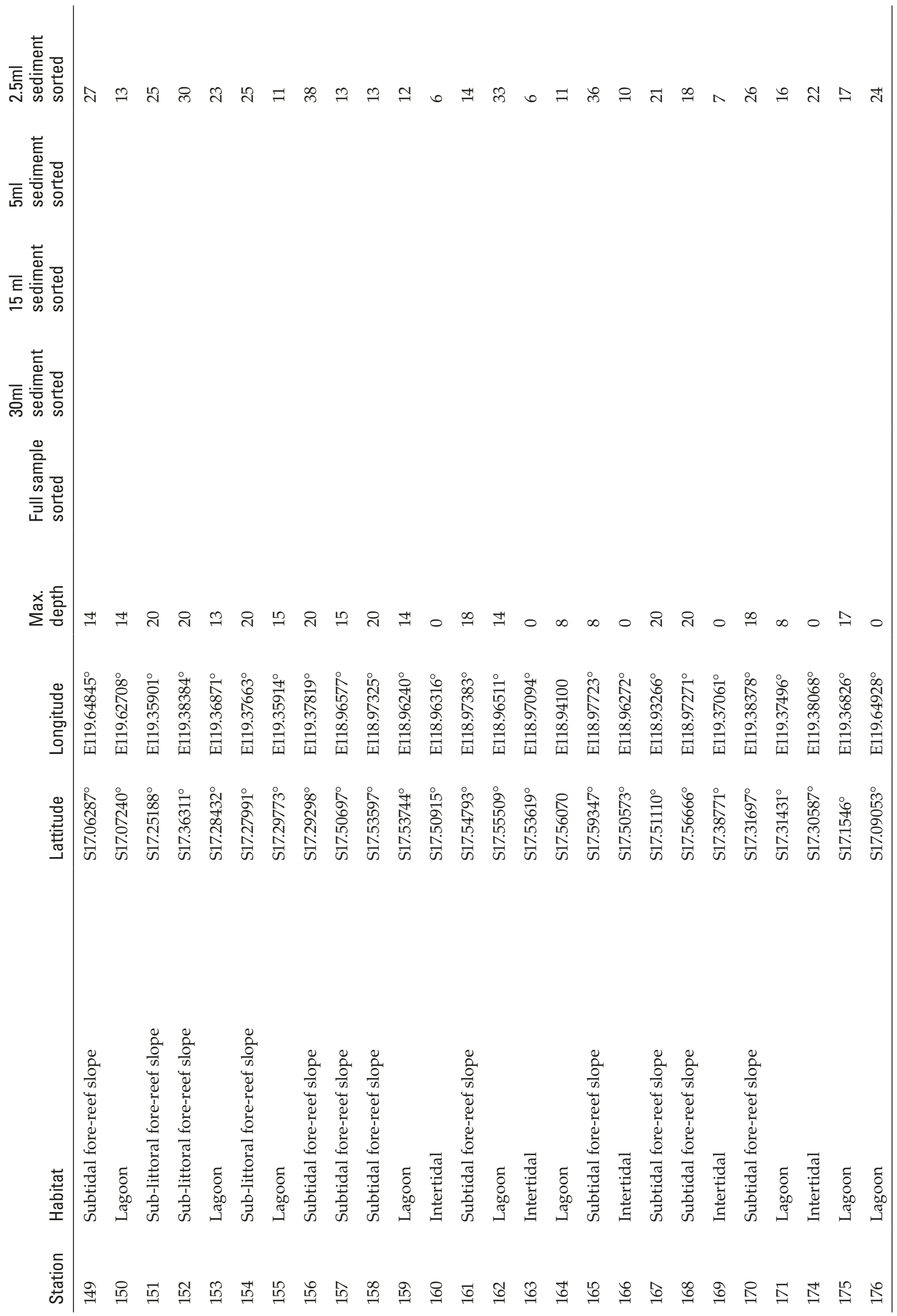


Skeneidae and Tornidae). The distributions for named species were checked in ALA as well as general literature to assess potential range extensions.

All taxa identified to species level or allocated an OTU were allocated a unique registration number (SXXXXX) and accessioned into the mollusc collection of the WAM.

The shells corresponding to OTUs were photographed with a Tucsen 10MP microscope camera or a Canon Eos 6D camera mounted on a variety of microscopes, including Wild Heerbrugg M7A, M3Z, Leica MZ16, M125 and M205. Images from the Canon $6 \mathrm{D}$ were focus stacked by hand setting the low area and high point focus and imaging five to ten points in between. These were then combined in Helicon Focus (http://www. heliconsoft.com/heliconsoft-products/heliconfocus/) to achieve the best depth of field.

Samples from this project were only subsampled once. Additional sorting effort would certainly generate more specimens and probably additional species. Live taken specimens from samples where only dead shells were found initially is also likely. Unsorted sediment samples are housed at the WAM.

\section{RESULTS}

This project involved approximately 1,000 hours of laboratory-based sorting, photography, identification, databasing and manuscript preparation. These hours do not include the time taken to accession the material into the WAM mollusc database.

Assessment of 77 stations and 1,883 identified specimen lots revealed 505 smaller mollusc species in the $\leq 5 \mathrm{~mm}$ adult size class (M), 43 species from $>5-10 \mathrm{~mm}$ adult size class (Me), 68 juvenile or subadult species from the $>10 \mathrm{~mm}$ adult size class (Ma), and 8 species whose adult size could not be determined (Table 2, Column 2).

A species accumulation graph (Figure 1) was generated to examine the effect each added station had on total diversity. The data illustrate the linear increase in diversity with each additional station. No asymptote was reached, indicating more taxa were being added at a constant rate for every additional station assessed.

For each family, the number of taxa reported in this study is presented alongside the numbers for that family from the Kimberley historic mollusc paper (Willan et al. 2015), to aid comparison (Table 2, Columns 4-5).

One hundred mollusc families were found in this study, compared with 209 families reported in the Kimberley historic mollusc paper (Willan et al. 2015), where it was noted that smaller molluscs were underrepresented. Of the 102 families or

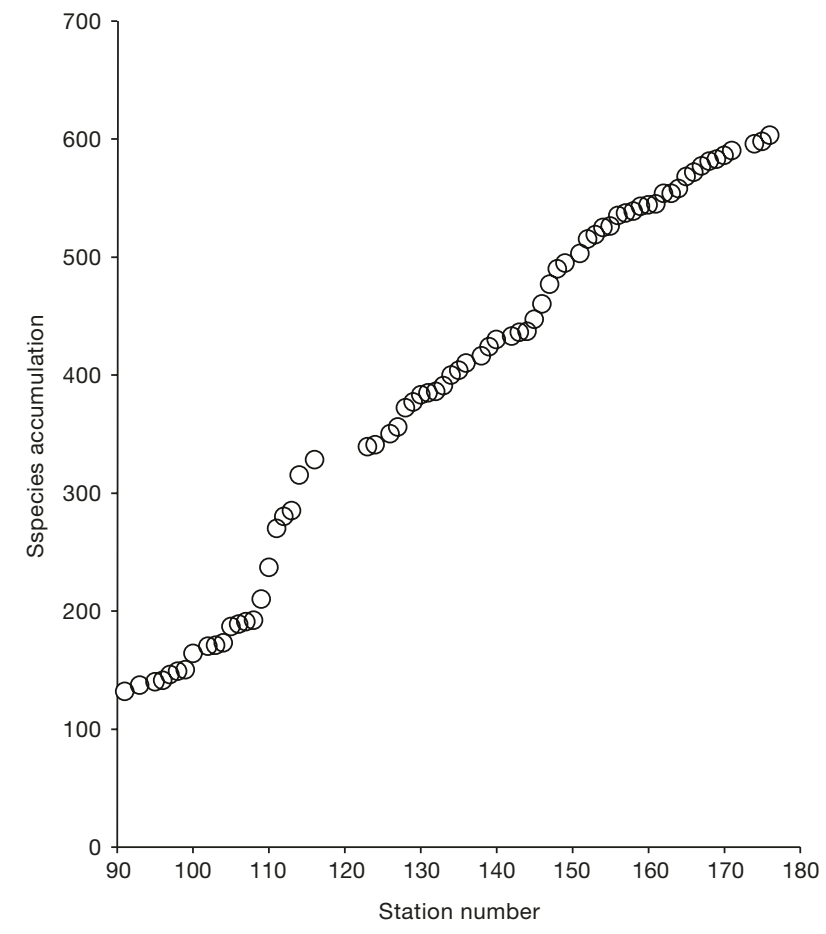

FIGURE 1 Species accumulation as a function of station number (= sample area/volume).

superfamilies reported here, a number of species were represented by juveniles or subadults of macromolluscs. These diversity counts are low compared to data presented in the historic dataset (solid bars at the top of chart, Figure 2). Conversely, 21 families were not documented in Willan et al. (2015) or ALA (1 March 2018) as occurring in north-western Australia, (open columns at the bottom of Figure 2). These were: Anabathridae, Condylocardiidae, Dialidae, Eatoniellidae, Horaiclavidae, Juliidae, Leptochitonidae, Litiopidae, Murchisonellidae, Neoleptonidae, Omalogyridae, Orbitestellidae, Pickworthiidae, Ringiculidae, Rissoellidae, Scissurellidae, Seguenzioidea (unplaced), Skeneidae, Sportellidae, Thraciidae and Tornidae (Table 2, Column 2). Groups with numerous microscopic taxa (e.g. rissoids/rissoinids, cerithiopsids and caecids) had a several-fold increase in the number of taxa known from the Kimberley.

This finding represents more than $20 \%$ of the entire diversity of families globally or an approximate $9 \%$ increase in total molluscan family diversity for the Kimberley region (209 families from Willan et al. 2015 and 21 additional from this paper).

In previously documented families, many additional records came to light, resulting in a doubling or more of taxa in the Atlantidae, Caecidae, Capulidae, Cerithiopsidae, Cylichnidae, Cystiscidae, Epitonidae, Eulimidae, Galeommatoidea, Iravadidae, Liotidae, Philinidae, Plesiotrochidae, Pyramidellidae, Rissoidae, Scaliolidae, Triphoridae and Vanikoridae (Table 2, Column 2). 


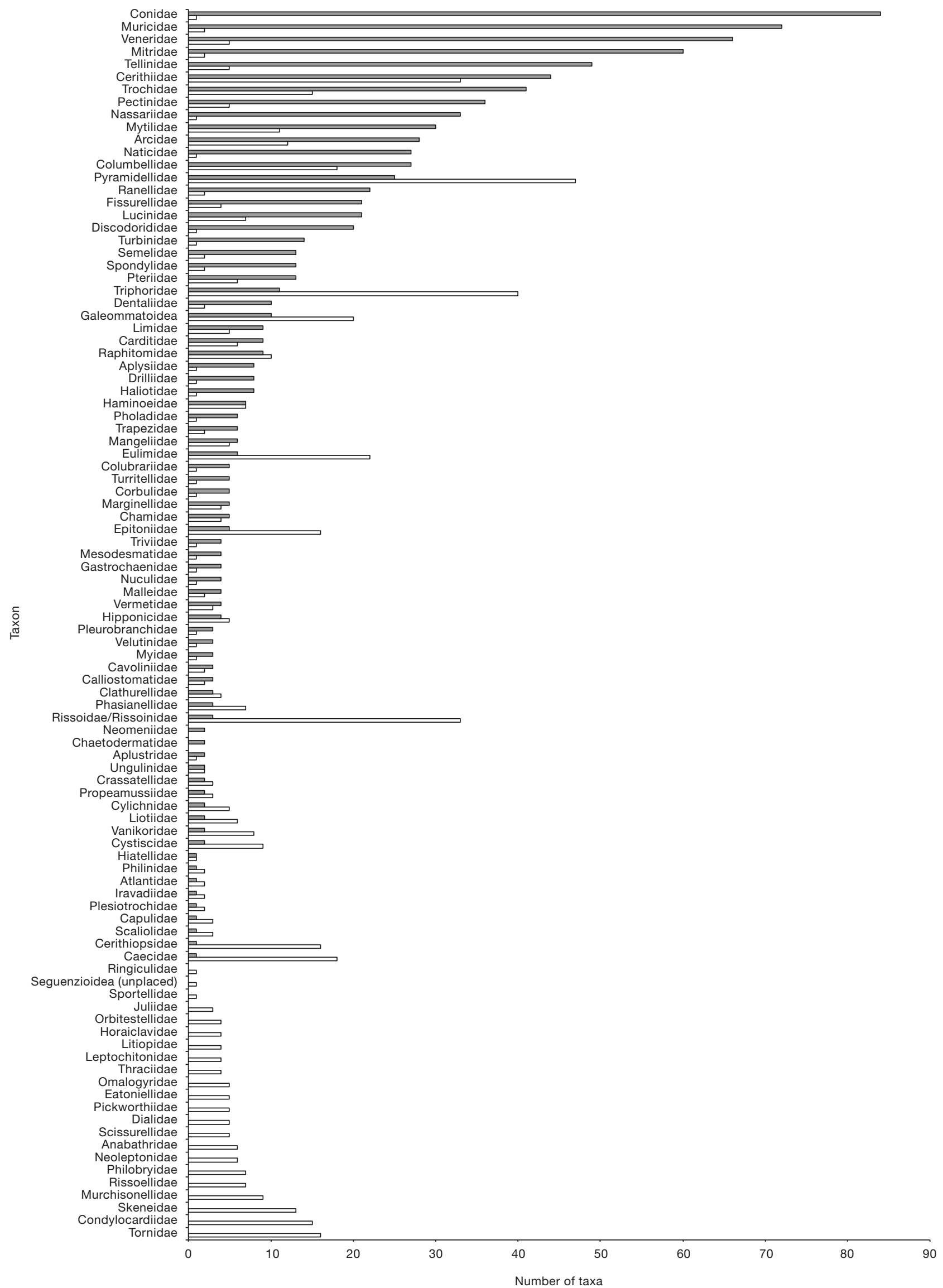

FIGURE 2 The number of species level taxa (grey = historical data, Willan et al. (2015); white bar = this survey data) in each family as presented in Willan et al. (2015) and this study. Families without any representation in this study have been omitted. 
The rarity of the species identified is shown in Figure 3, with just over half of the species found only once during the entire project, while almost $70 \%$ were found only once or twice.

\section{THE TEN MOST COMMON SPECIES}

Of the most commonly encountered species in this project, nine were microgastropods and one was a bivalve macromollusc (Figure 4).

The most frequently occurring species overall was Parashiela cf. invisibilis (Hedley, 1899) (KimMoll326) (Figure 4A), which was found live in 43 samples across all depths. Records for species of Parashiela are sparse in north-western Australia with only two records known from the Project Area (ALA, 2018). The second most common species was Lophocochlias parvissimus (Hedley, 1899) (KimMoll18) (Figure 4B) identified from 39 samples and found at all sampled depths. This species was originally placed in Liotia by Hedley (1899: 554-555, Figure 67) based on material collected at Funafuti Atoll in the western Pacific (see discussion below).

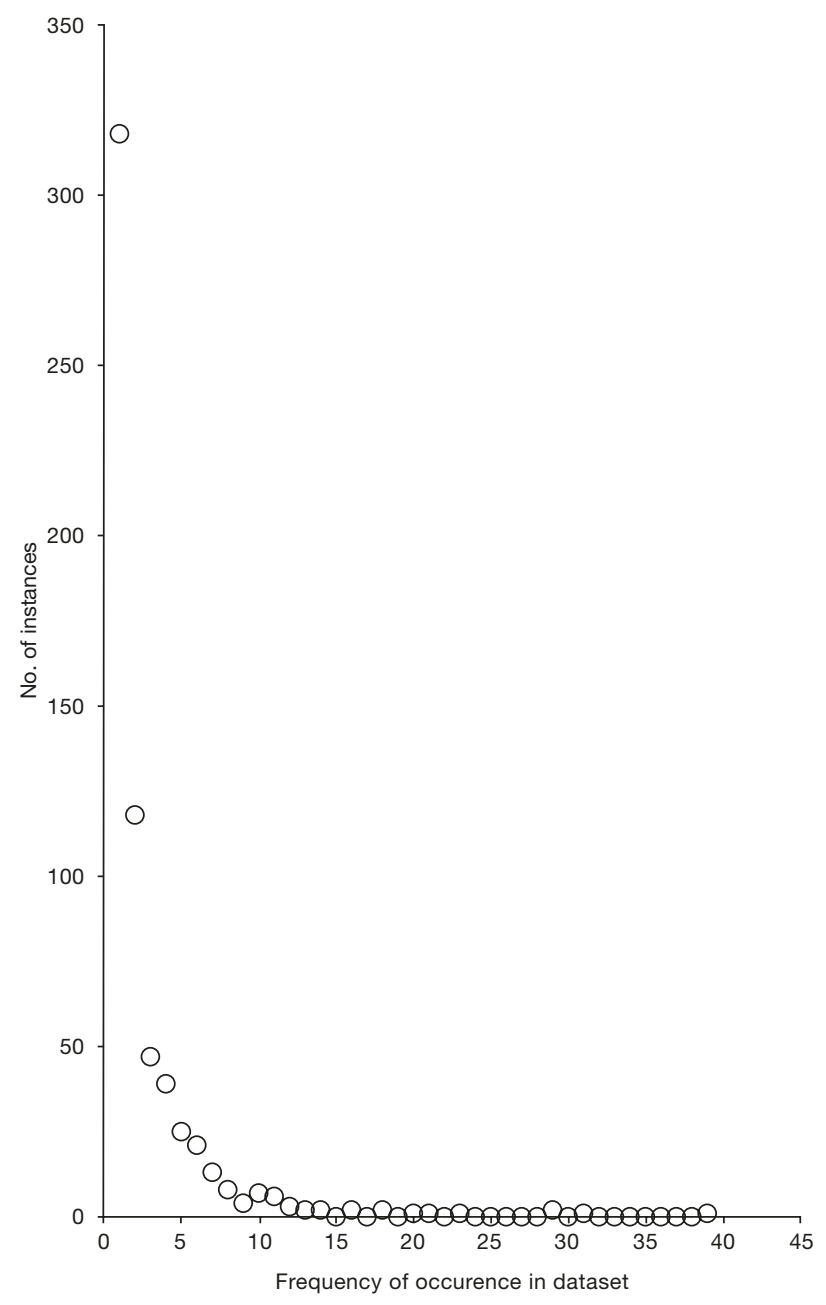

FIGURE $3 \quad$ Number of instances (frequency of occurrence) species were found in the dataset.
Cerithidium perparvulum (Watson, 1886) (KimMoll74) (Figure 4C), was the third most common species and found at 37 localities. It was encountered live from the intertidal to $13 \mathrm{~m}$ depth, with dead shells found at deeper depths. The only readily available information about the distribution of this species is its presence in the Indo-Pacific Ocean with ingression into the Mediterranean Sea. In Australia it has been recorded from tropical northern Queensland (Qld), Gulf of Carpentaria and Northern Territory (NT) (Online Zoological Collections of Australian Museums (OZCAM) and AFD). No records are available from WA and it is here considered a new record for the state. Apataxia cerithiiformis Tryon, 1887 (KimMoll314) (Figure $4 \mathrm{D})$ is the fourth most common species found in 30 localities. Scissurella cf. quadrata Geiger and Jansen, 2004 (KimMoll4) (Figure 4E) was common, found at 25 stations followed by the caecid, Caecum sepimentum de Folin, 1868 (recorded as Caecum lilianum Hedley, 1903 in most databases in Australia, see Pizzini et al. (2013) (KimMoll14) (Figure 4F). The type locality for the latter species is Maurice, La Réunion (lectotype, Muséum national d'Histoire naturelle (MNHN) type collection) and it has been recorded from 11 localities in eastern Australia, most commonly at Masthead Reef, Qld (ALA) yet, the only comment about distribution made by Pizzini et al. (2013) was that C. sepimentum exists in Australia.

The most common bivalve was Septifer cumingii Récluz, 1849 (KimMoll52) (Figure 4G) and it was the seventh most common mollusc, found at 22 stations. Live specimens were recorded from the intertidal to $13 \mathrm{~m}$ depth. Previously known as Septifer australis Laseron, 1956, this name has now been synonymised with S. cumingii (AFD, Huber 2010). Two additional species were found in samples from 21 stations; Pandalosia ephamilla (Watson, 1886) (KimMoll11) (Figure 4H) (Warén, 1983, Figures 71, 72), and the, as yet, unidentified eatoniellid (KimMoll360) (Figure 4I) (Winston Ponder personal communication).

\section{NOTEWORTHY STATIONS}

With a total of 132 species, station 91/K12 was the most diverse of the 77 stations surveyed. The sample was part of the initial sorting trial for smaller molluscs and proved too labour intensive to complete sorting. Based on the unsorted material remaining, this sample is estimated to contain in excess of 200 species. The site is a high energy deposition plain north-west of Montgomery Reef, between the Bonaparte and Buccaneer Archipelagos (Bryce et al. 2018). The sediment at the site has been sorted by subsea tidal currents leaving a coarse accumulation of comminuted shells and broken coralline rubble rich in small molluscs. No living specimens were encountered in the sample. 

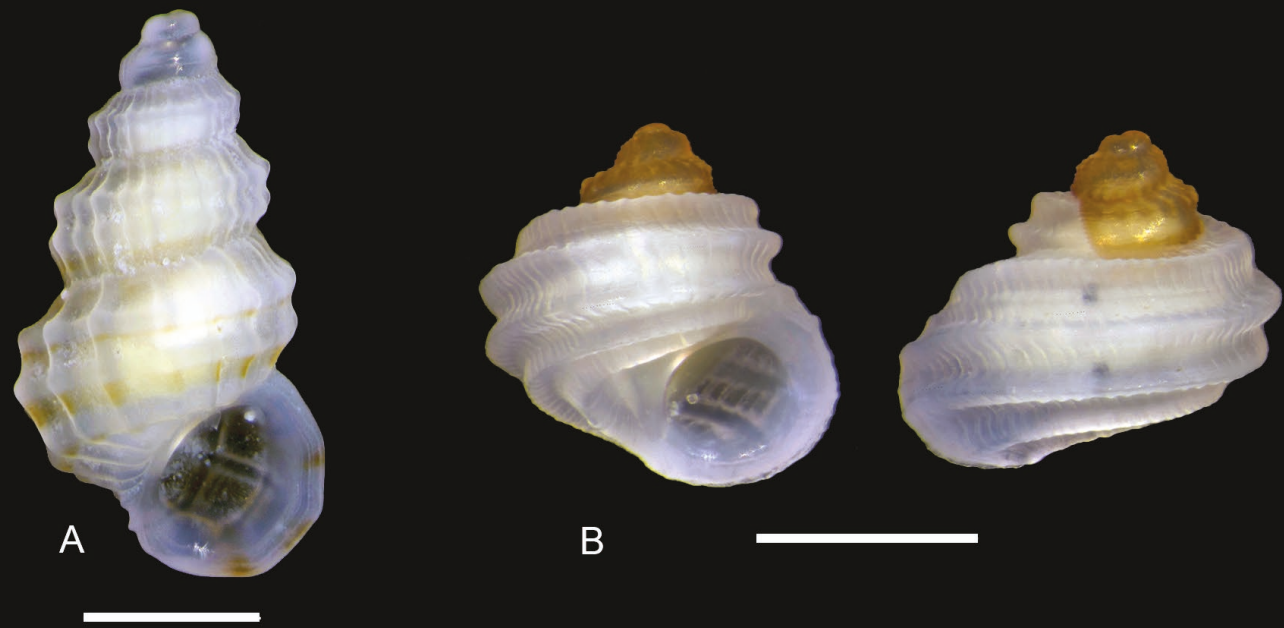

B
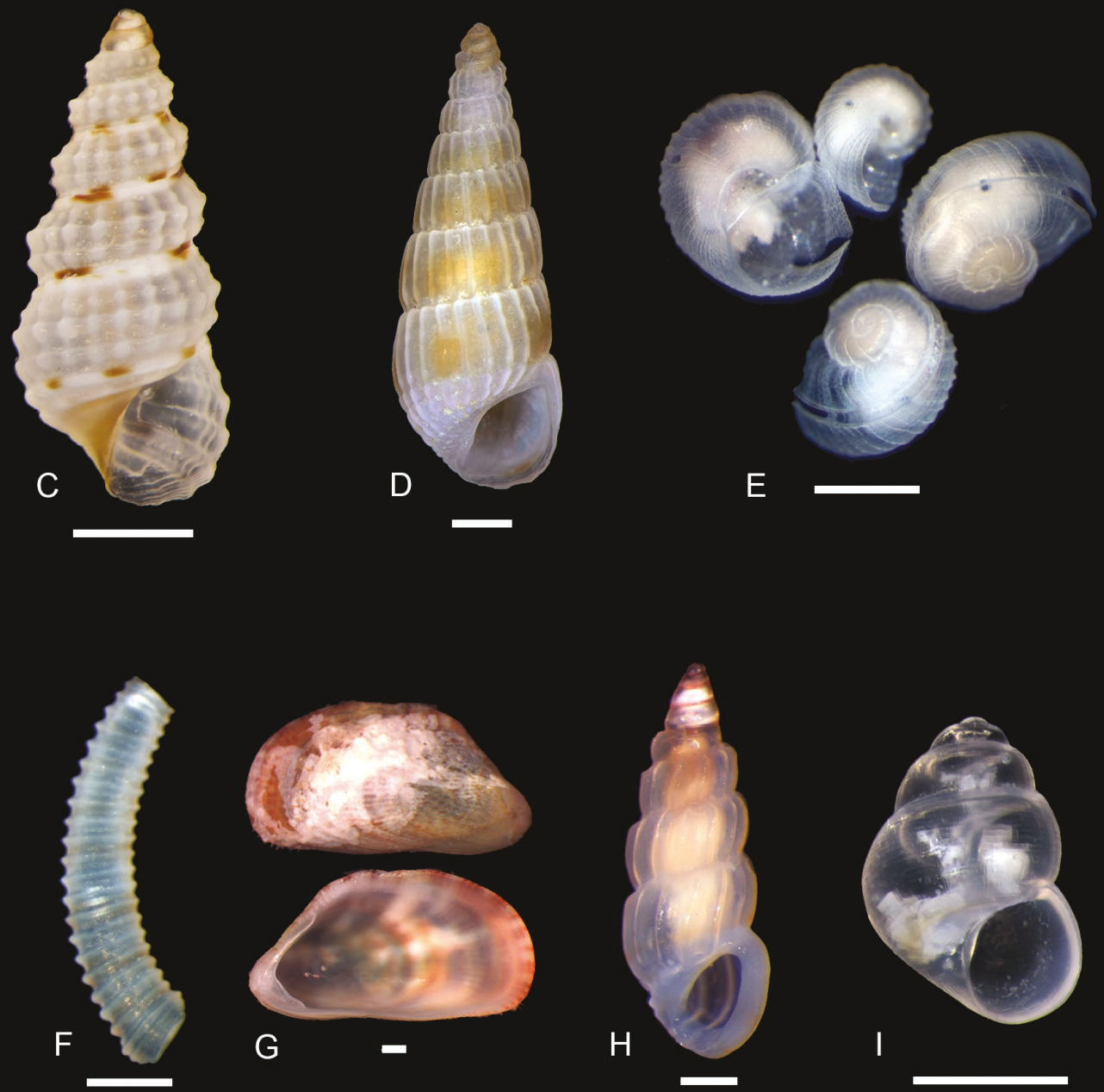

G

-
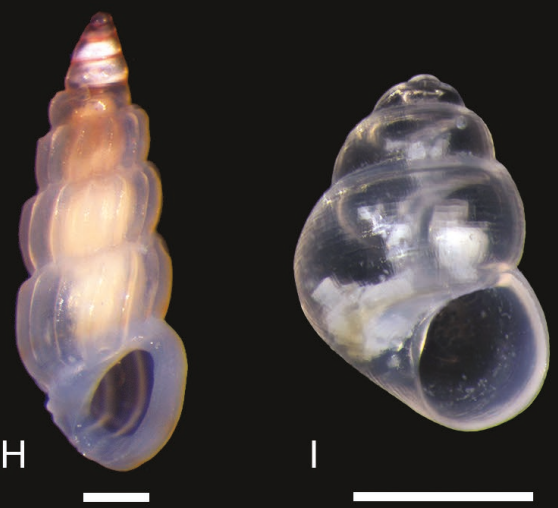

FIGURE 4 Most common species found. A) Parashiela cf. invisibilis (Hedley, 1899) (KimMoll326, WAM S94001); B) Lophocochlias parvissimus (Hedley, 1899) (KimMoll18, WAM S94346); C) Cerithidium perparvulum (Watson, 1886) (KimMoll74, WAM S94246); D) Apataxia cerithiiformis Tryon, 1887 (KimMoll314, WAM S94319); E) Scissurella cf. quadrata Geiger and Jansen, 2004 (KimMoll4, WAM S84509); F) Caecum sepimentum de Folin, 1868 (KimMoll14, WAM S84515); G) Septifer cumingii Récluz, 1849 (KimMoll52, WAM S84953); H) Pandalosia ephamilla (Watson, 1886) (KimMoll11, WAM S84851); I) Eatoniellidae (KimMoll360, WAM S68921). Scale bars 500um. 


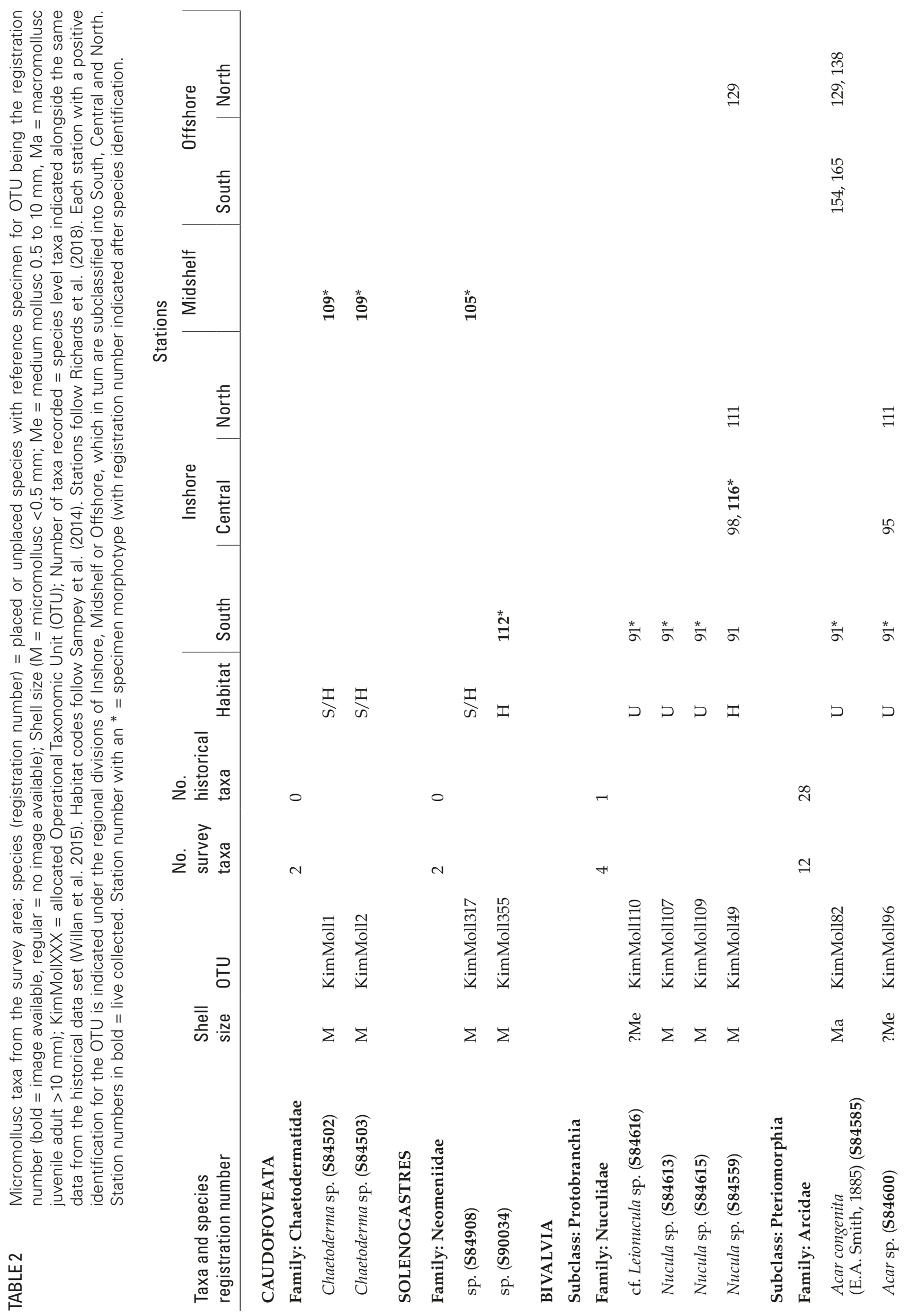




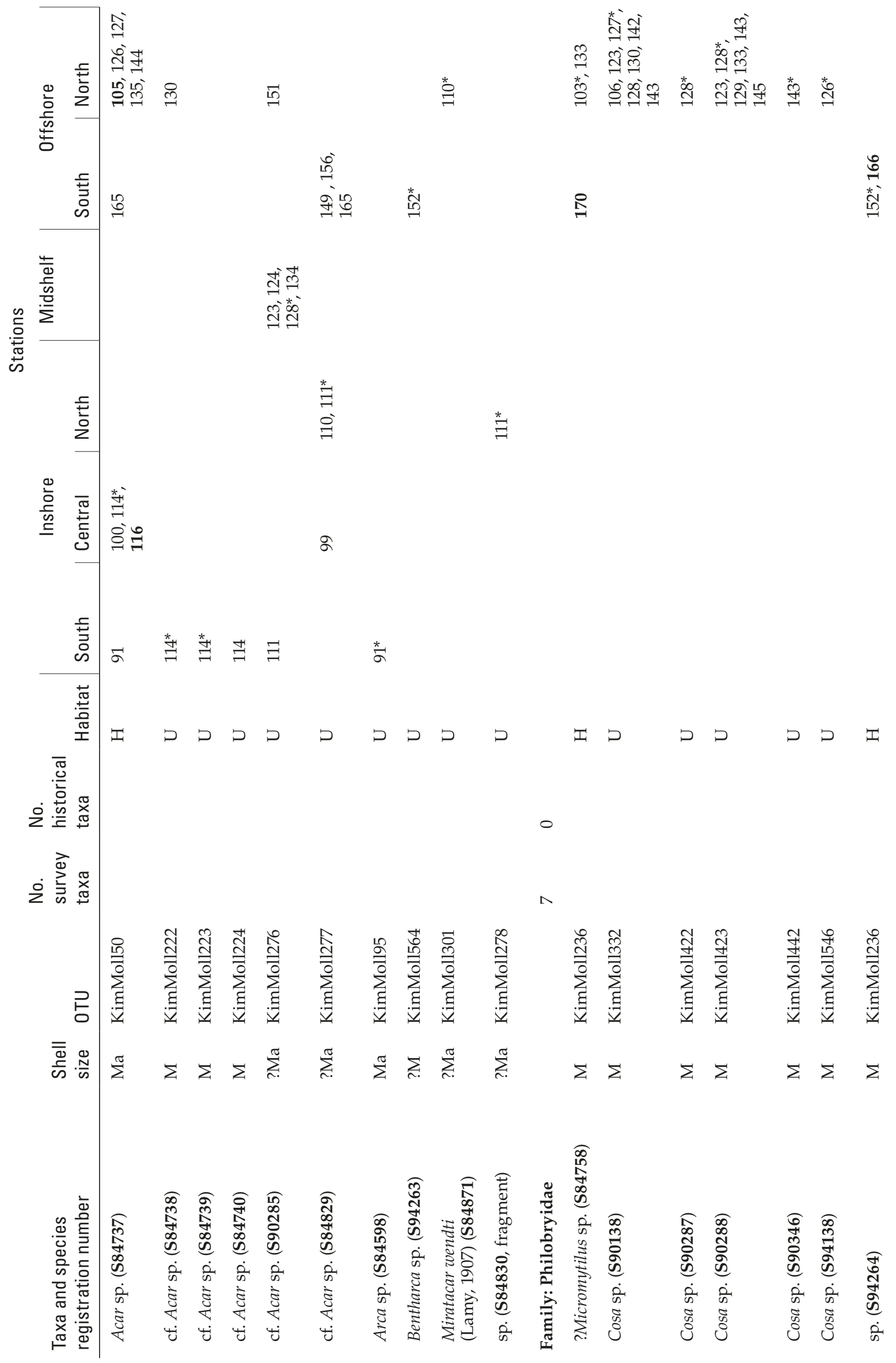




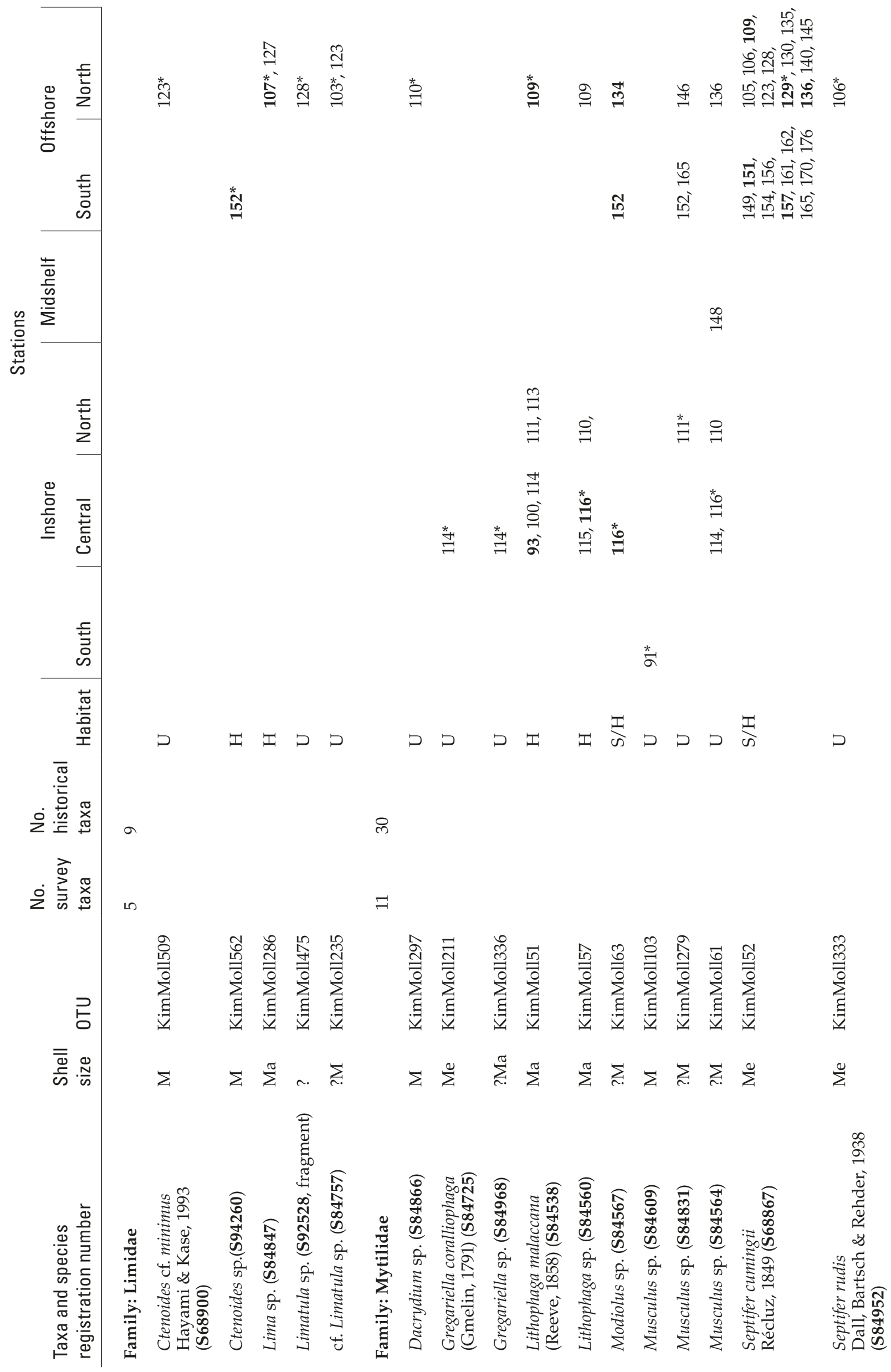




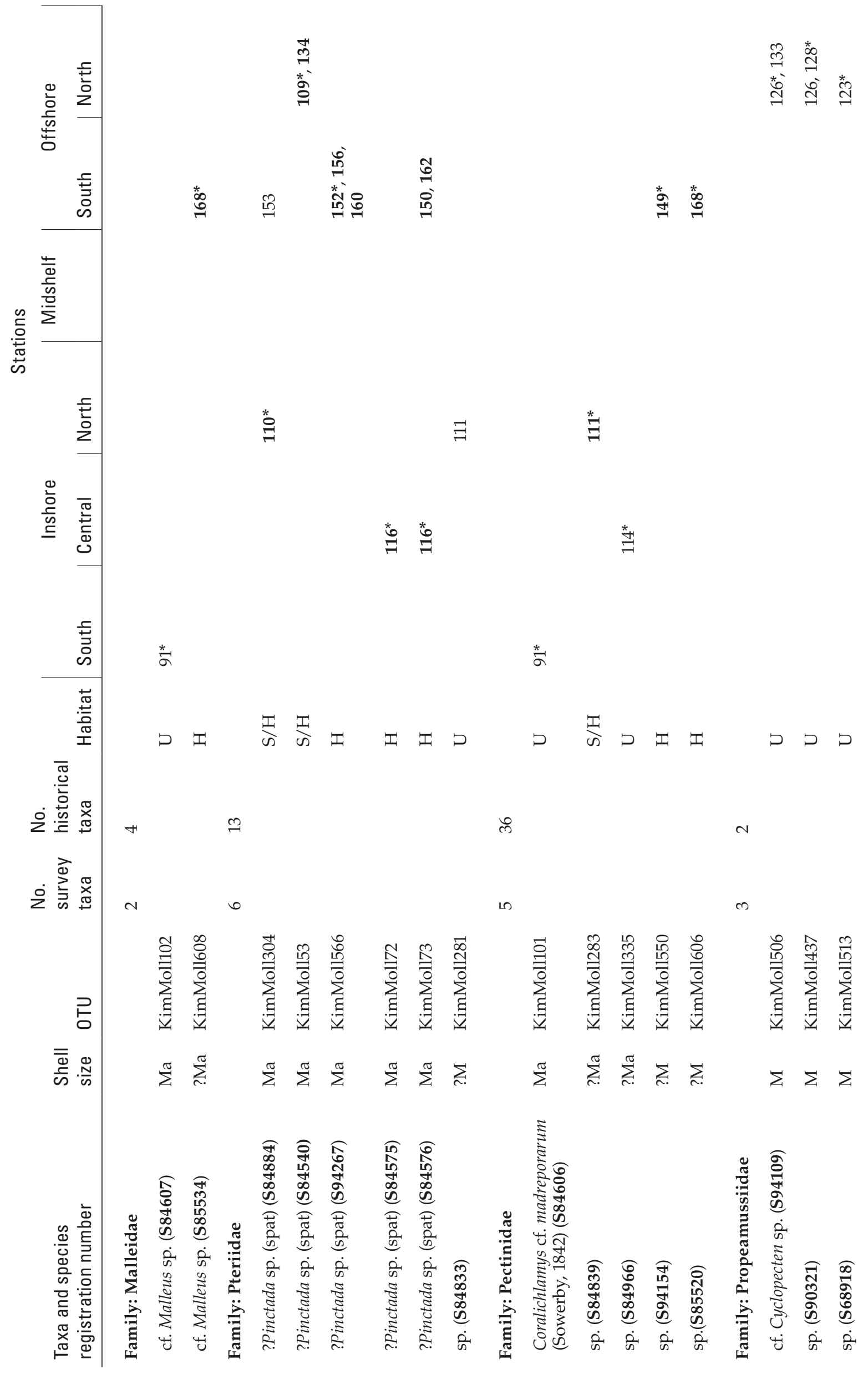




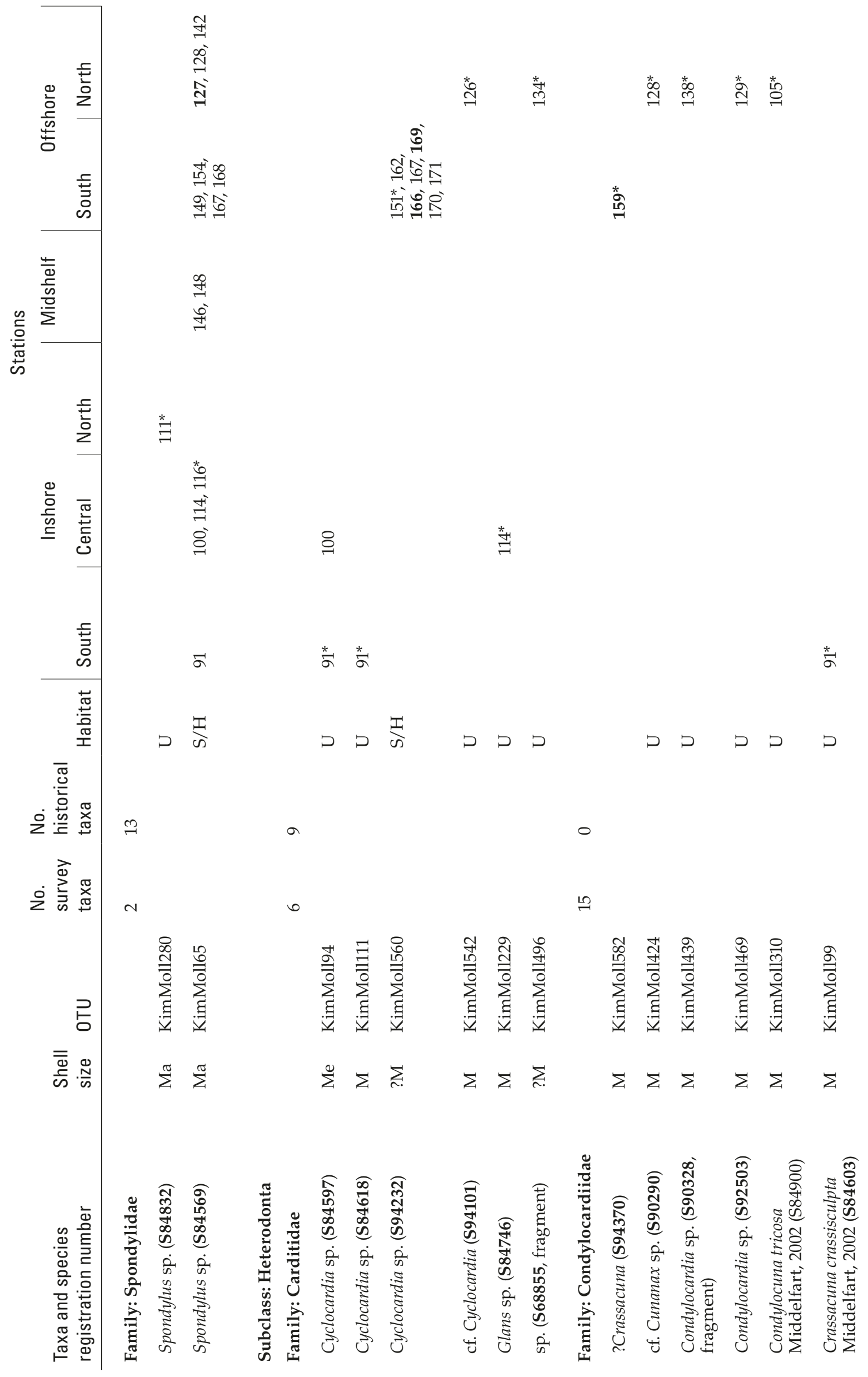




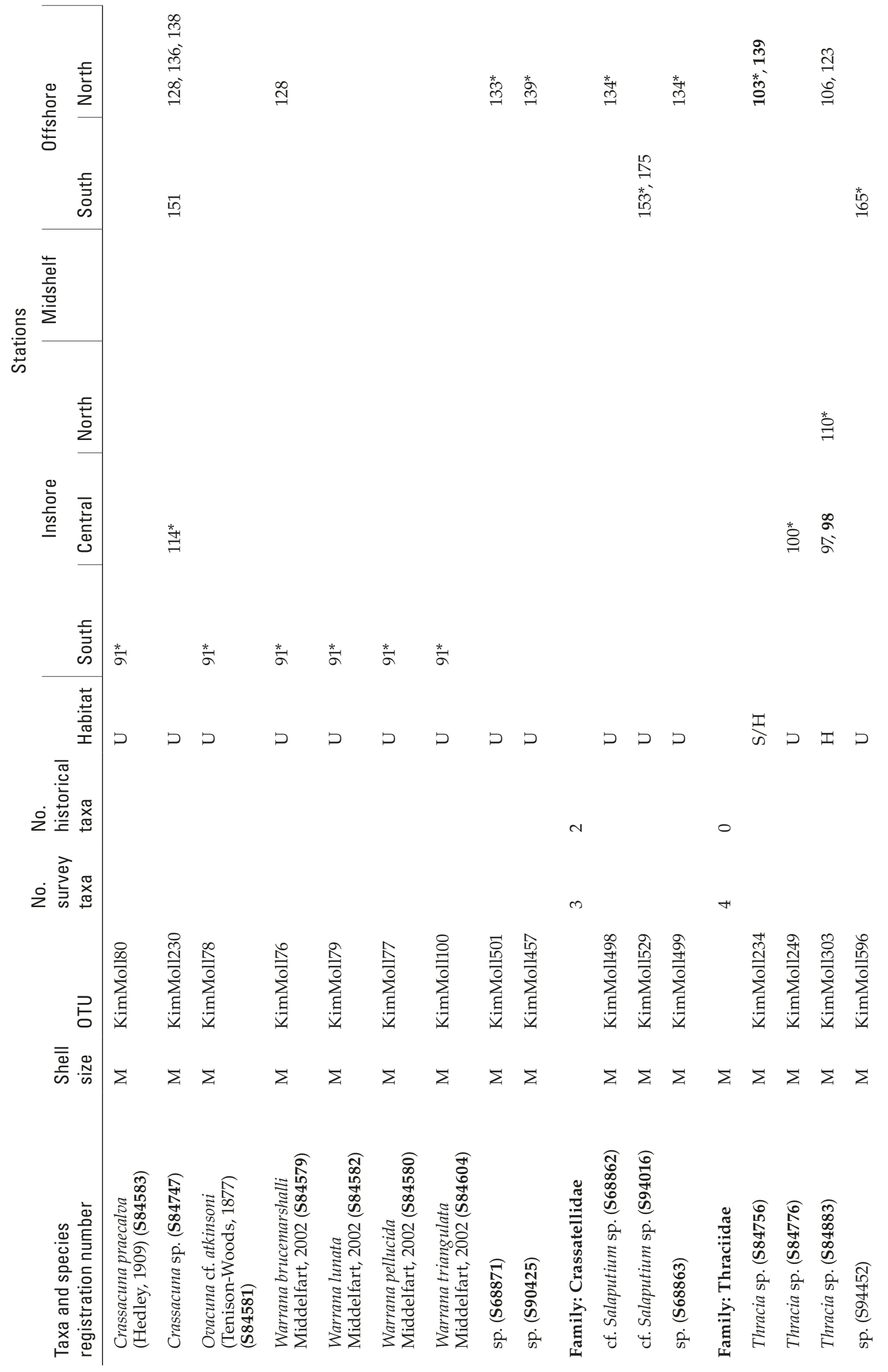




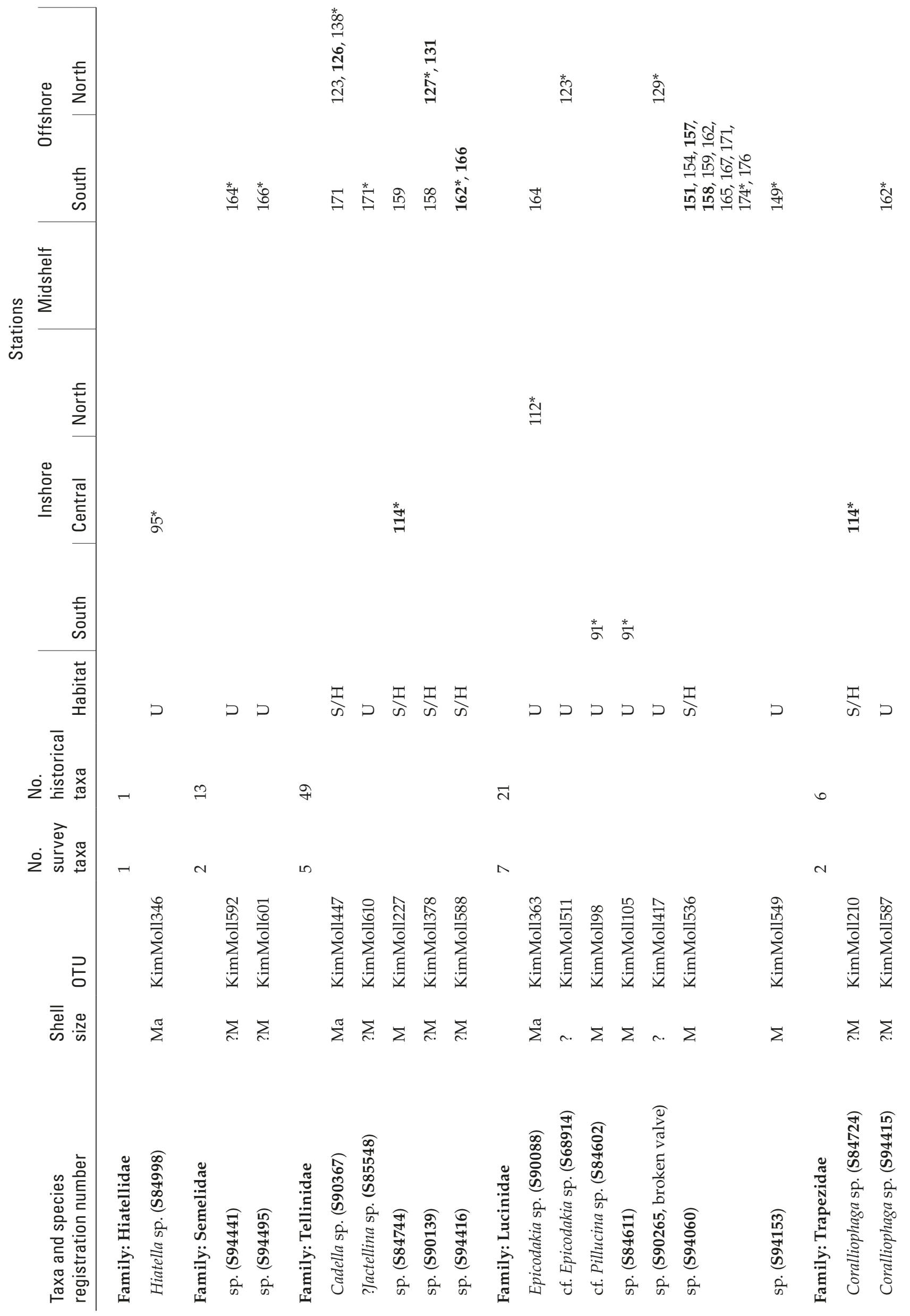




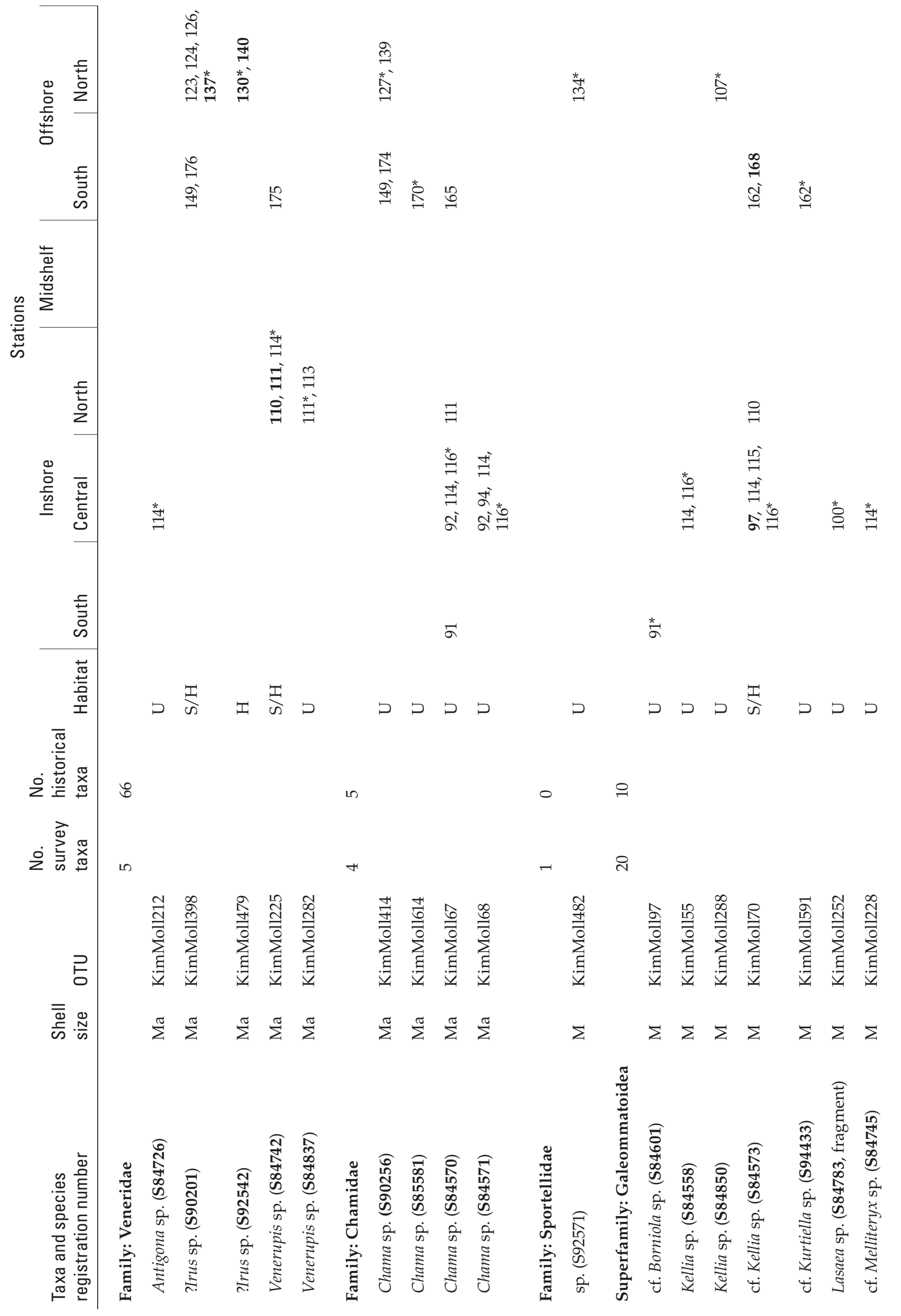




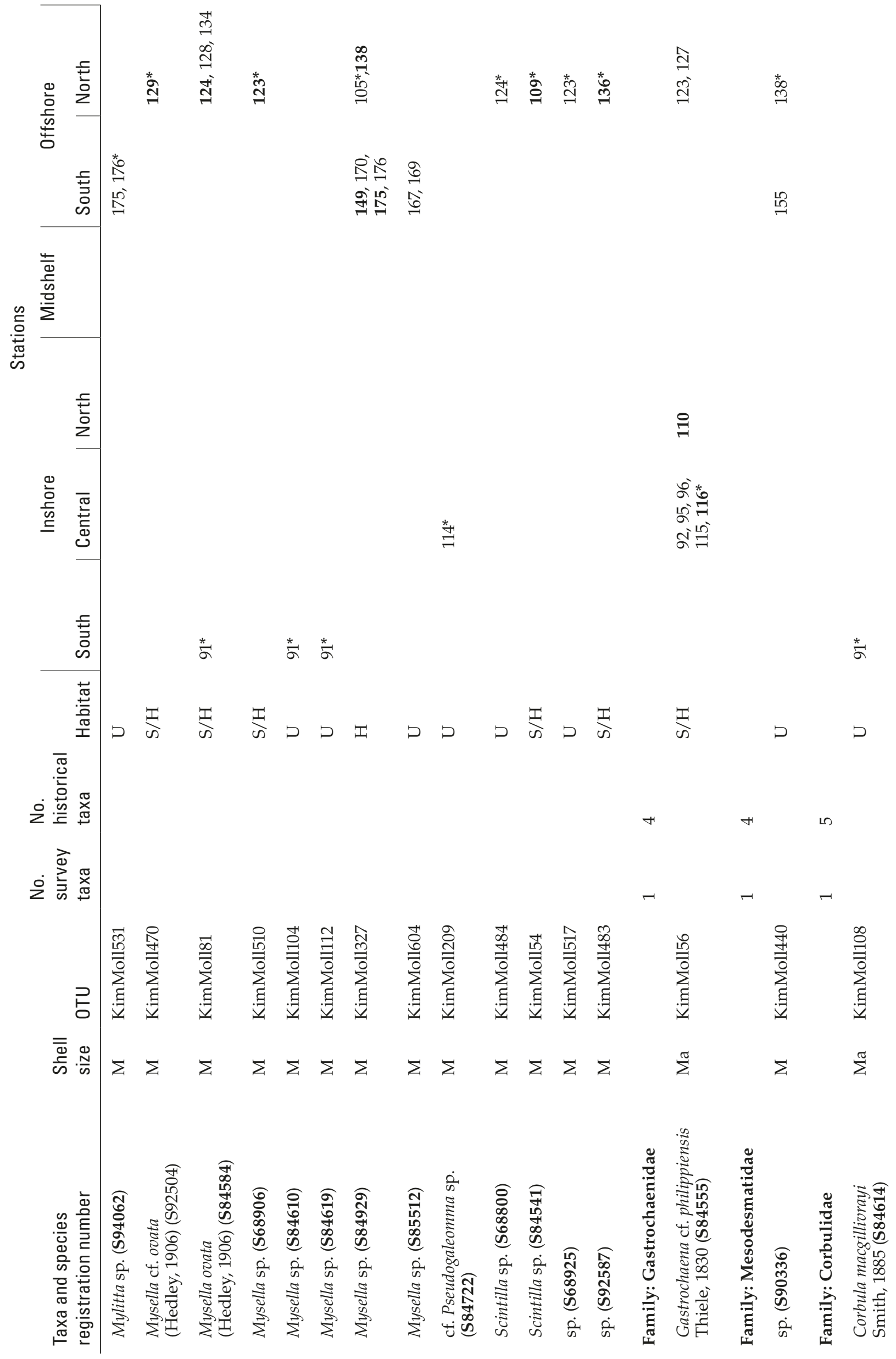




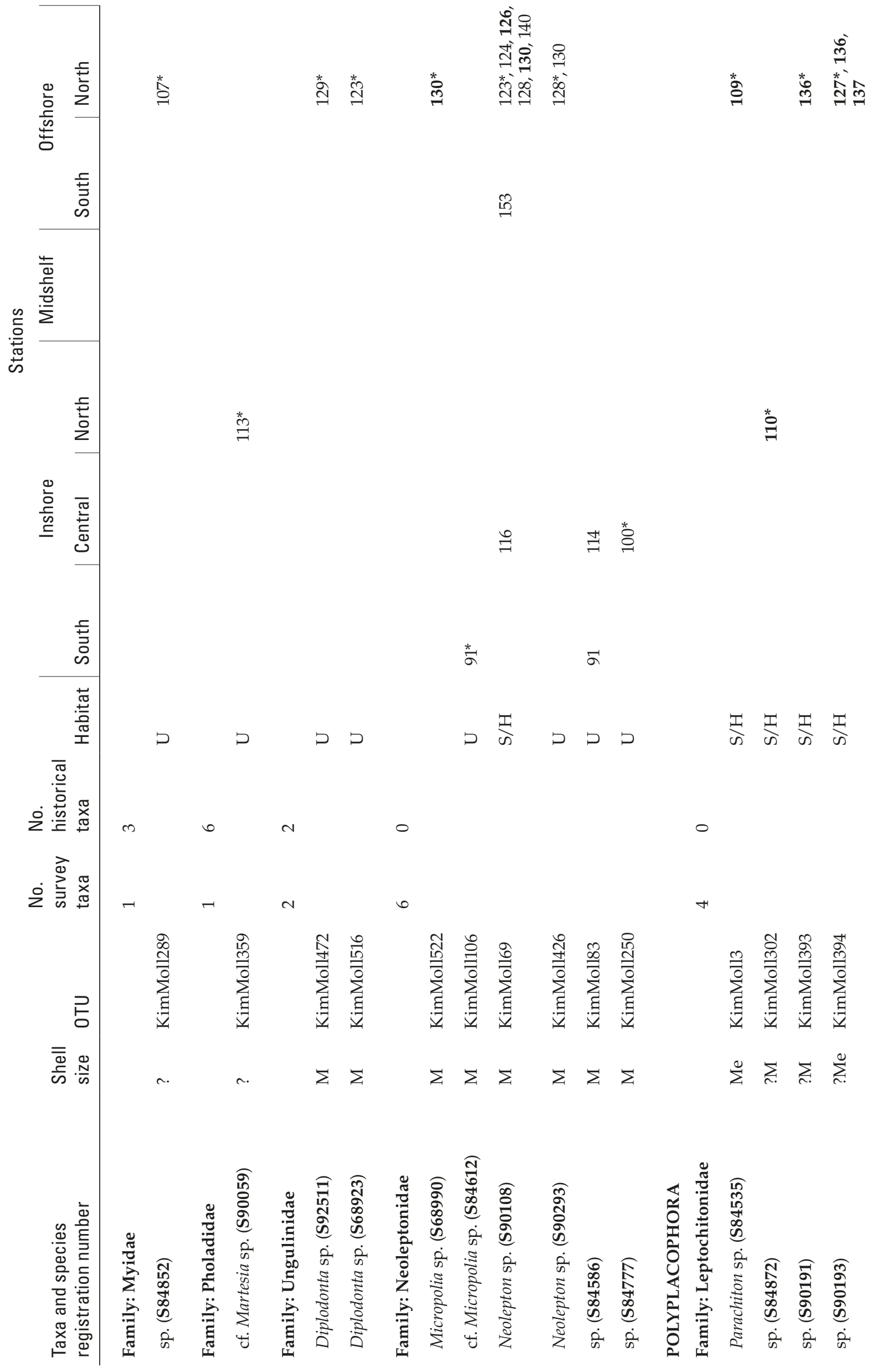




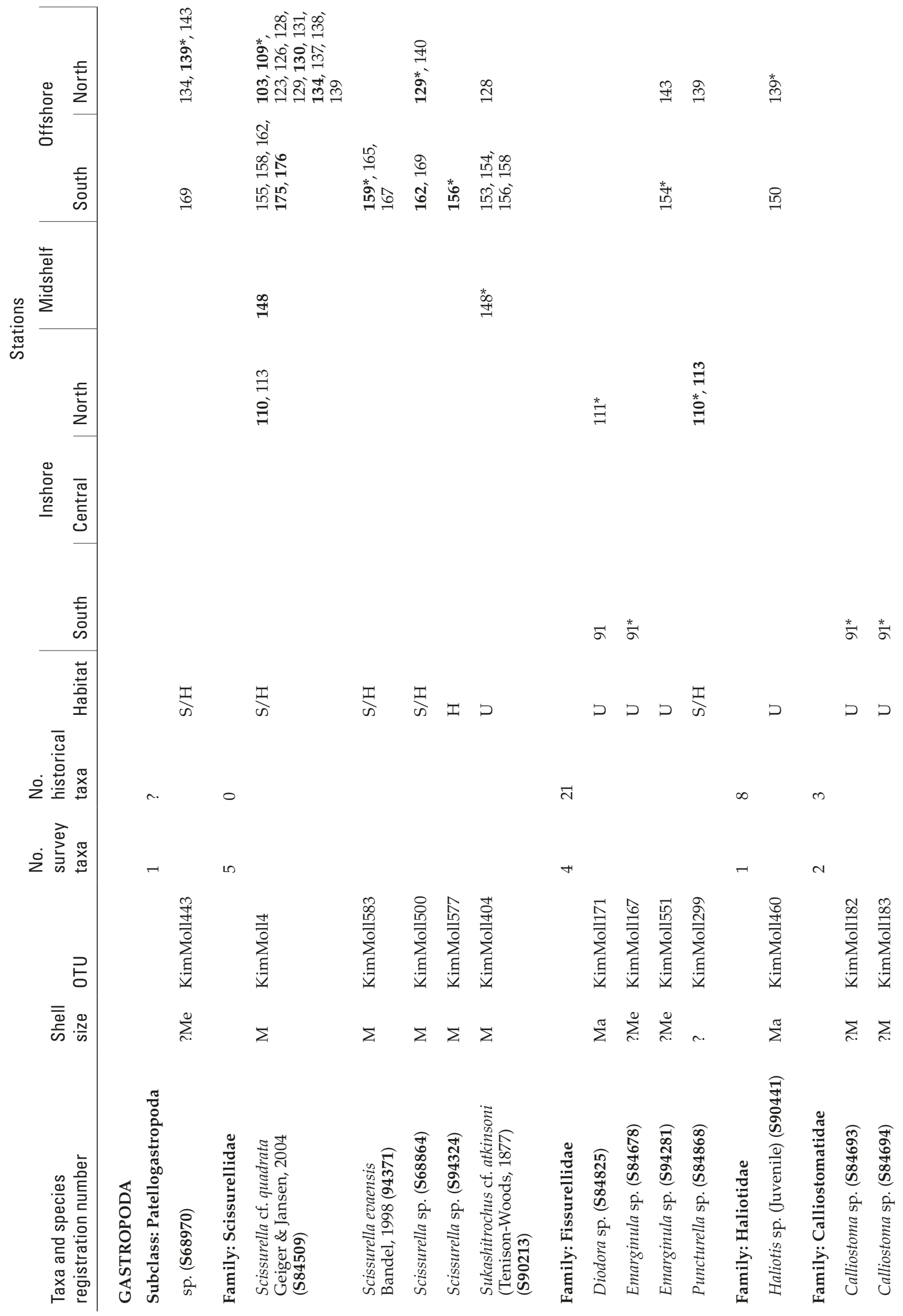




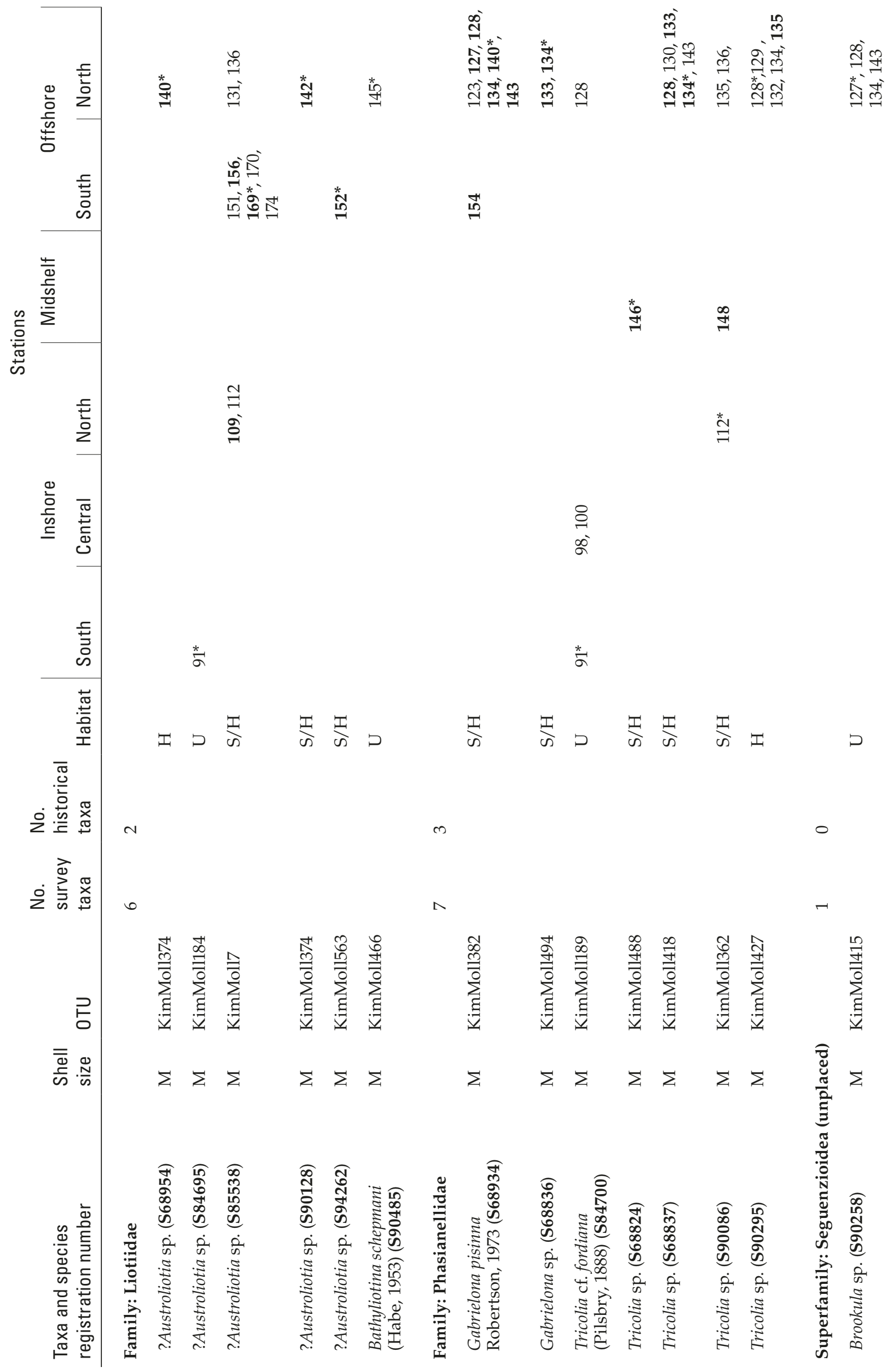




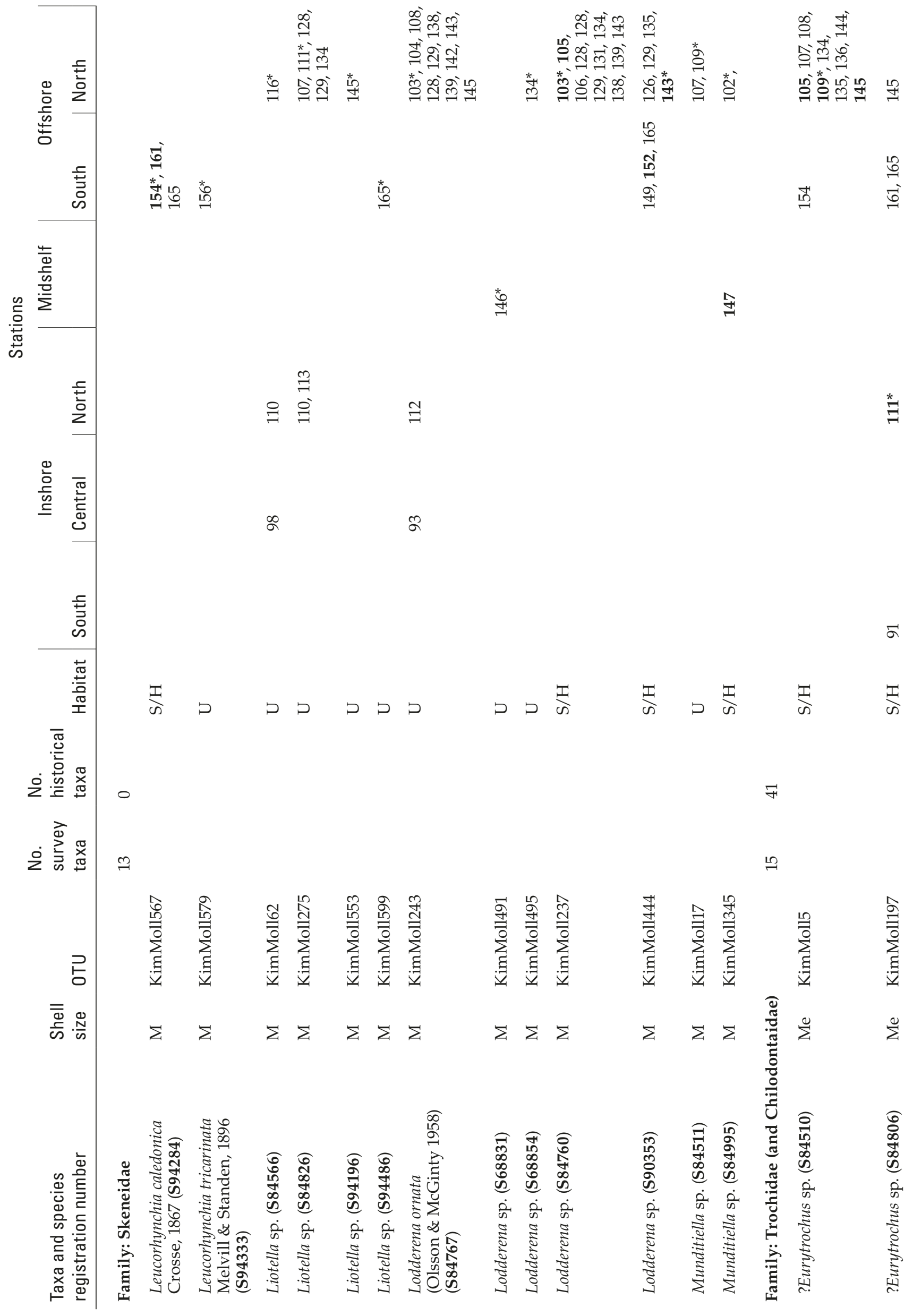




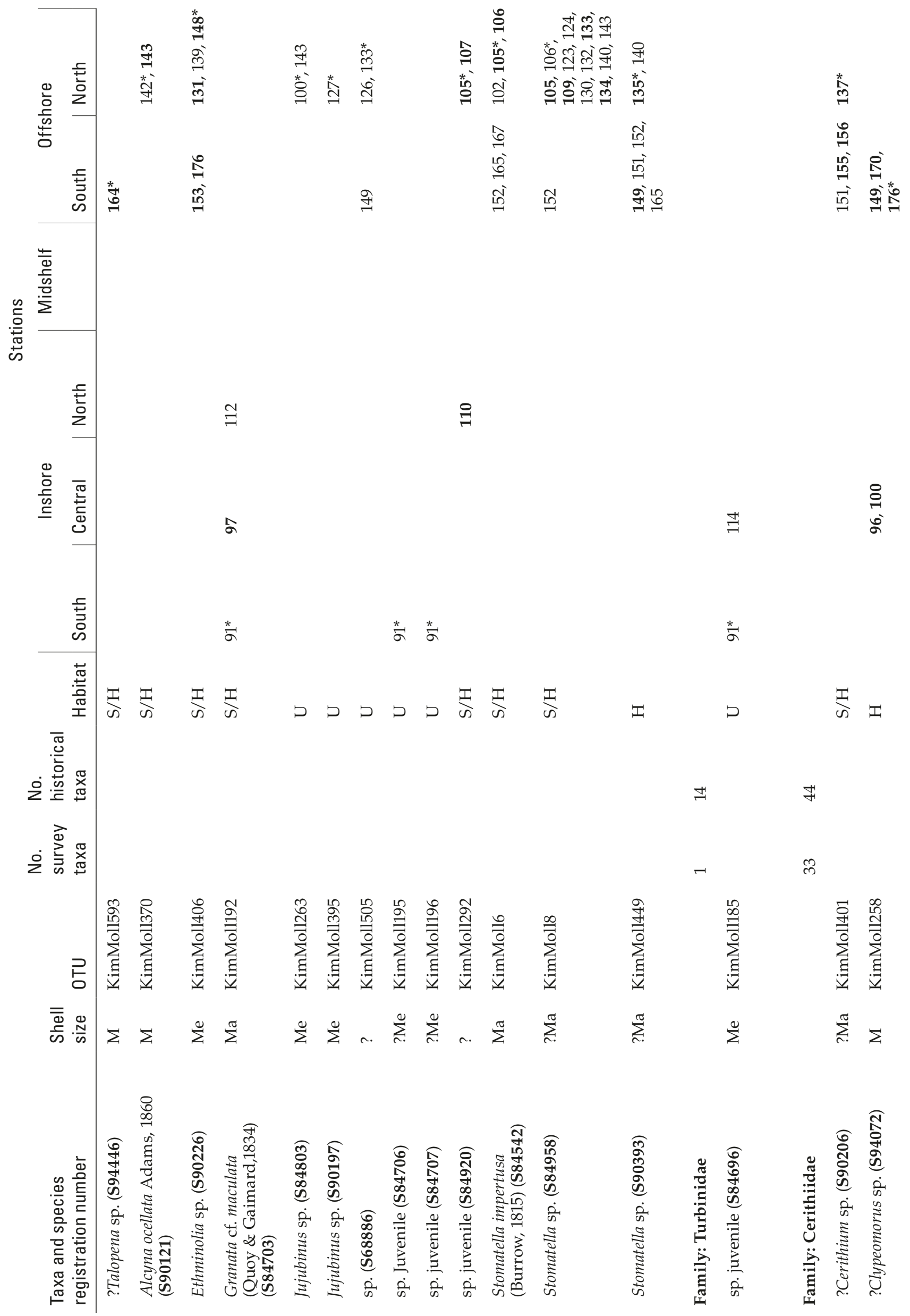




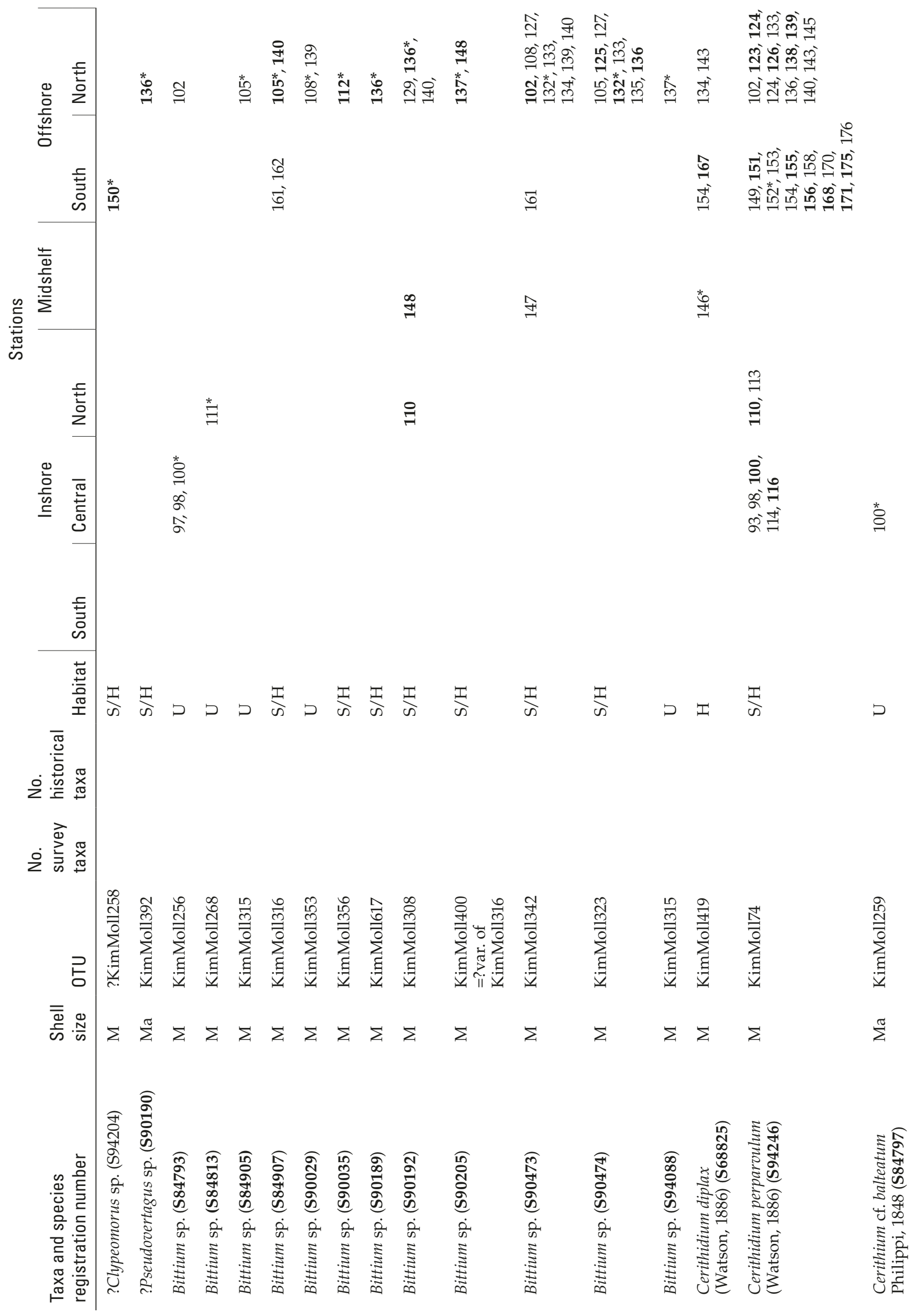




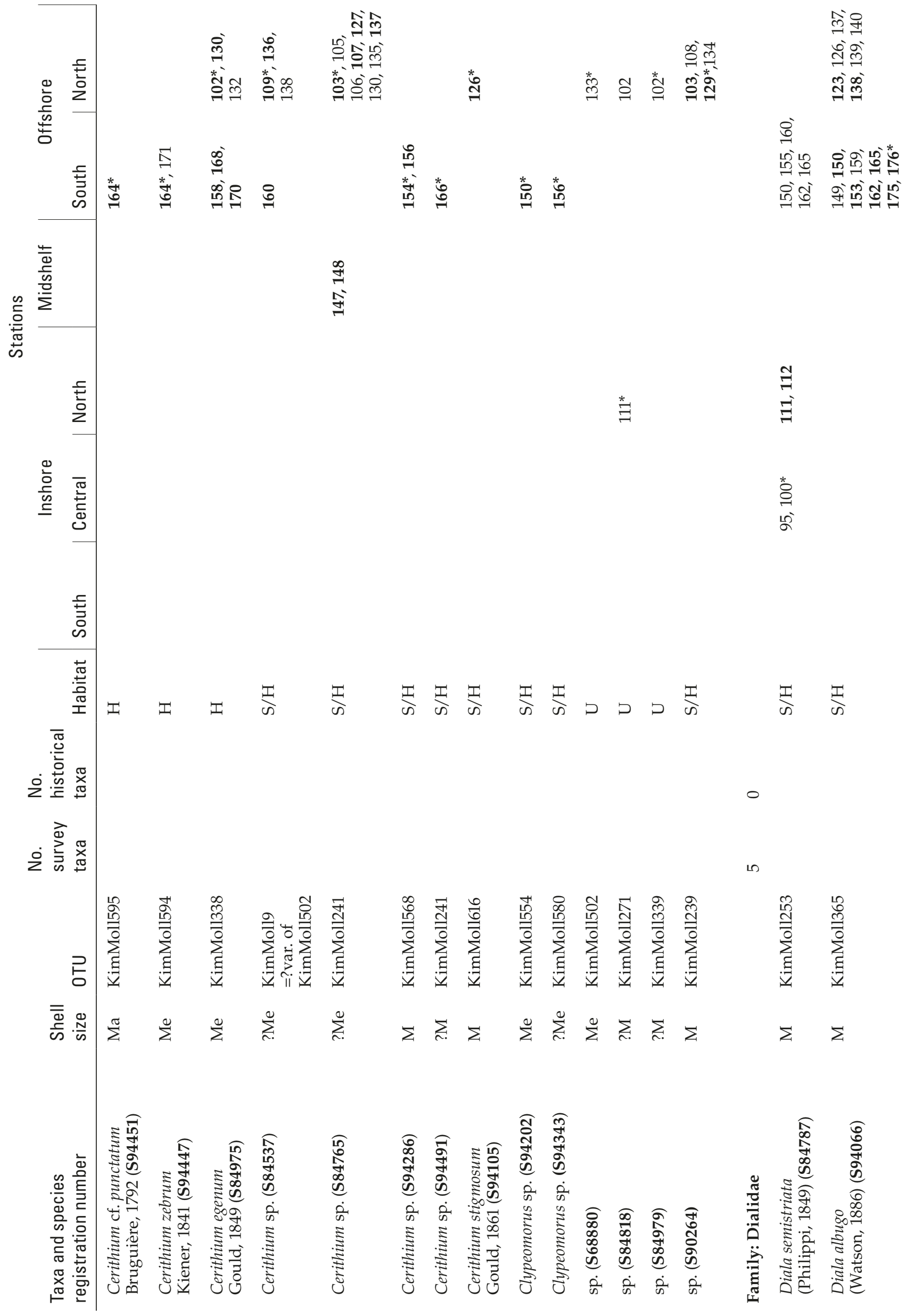




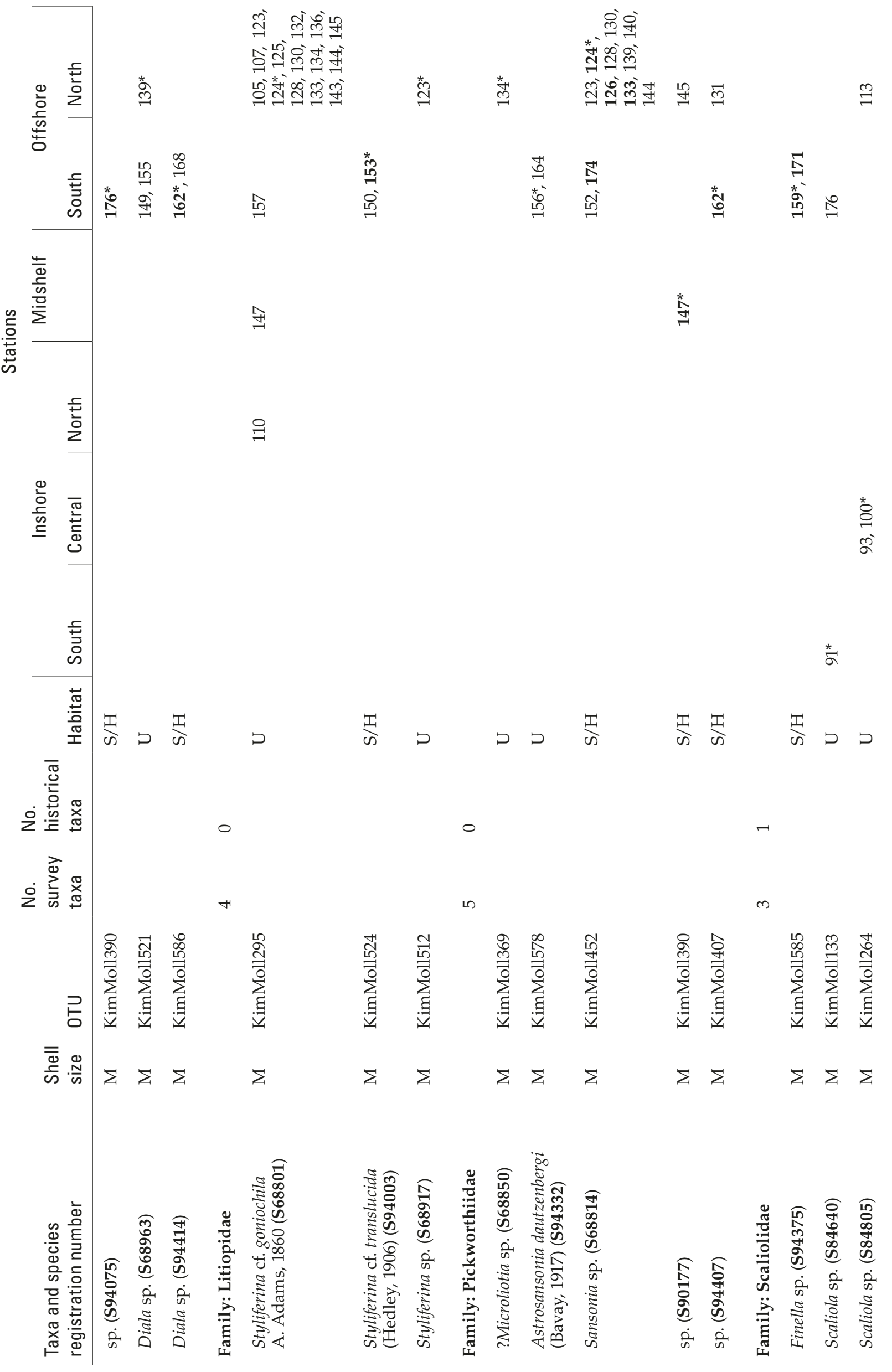




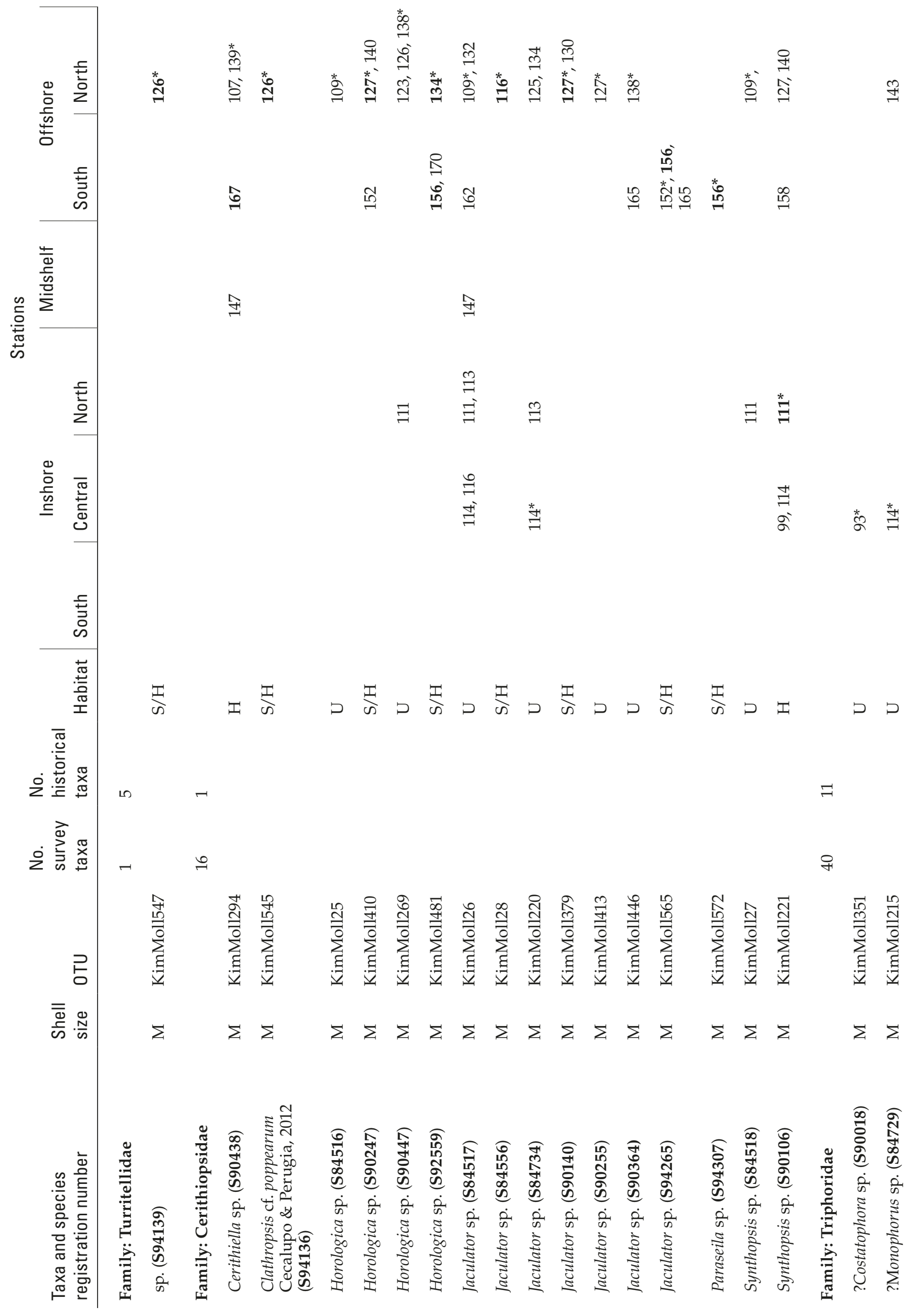




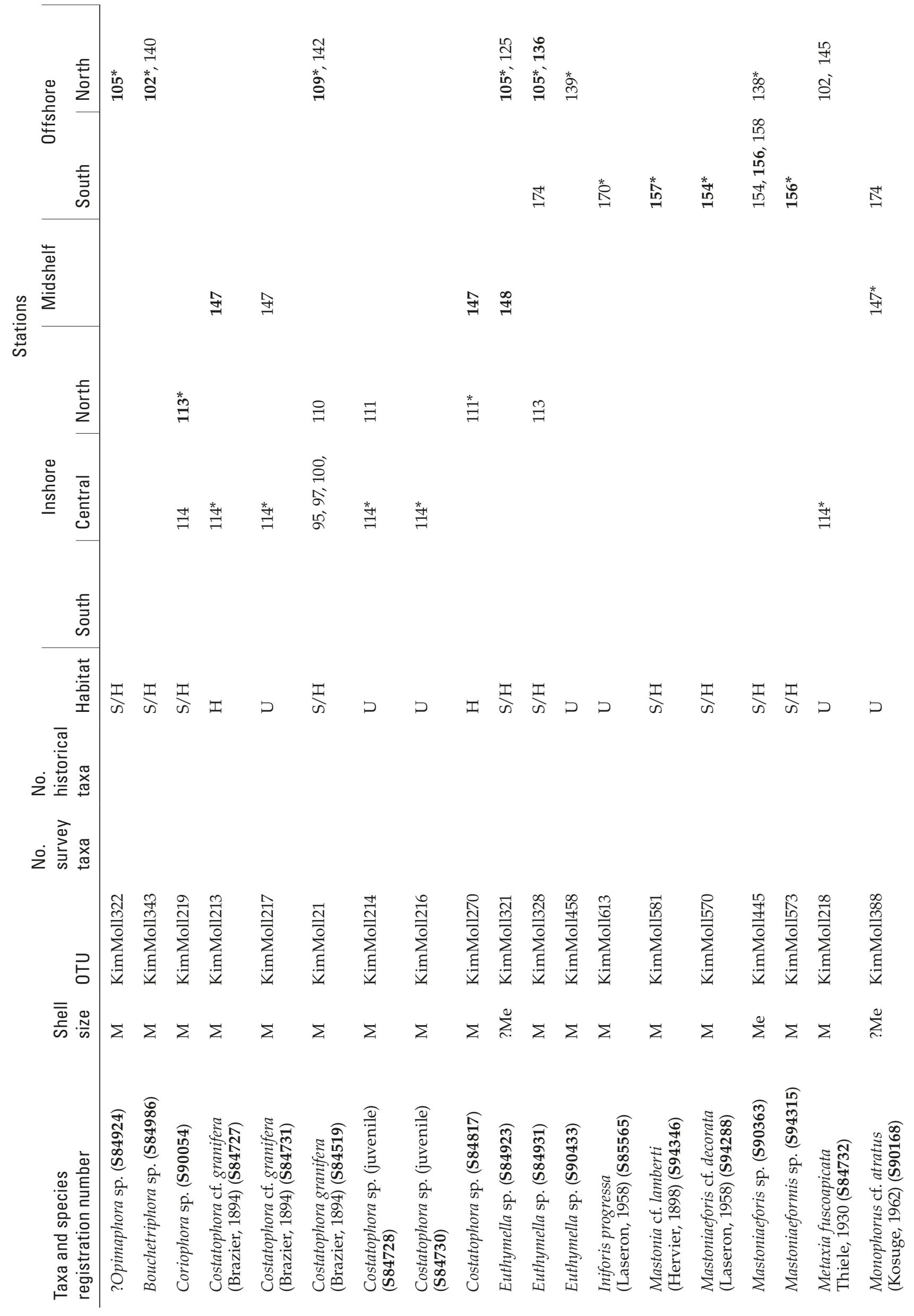




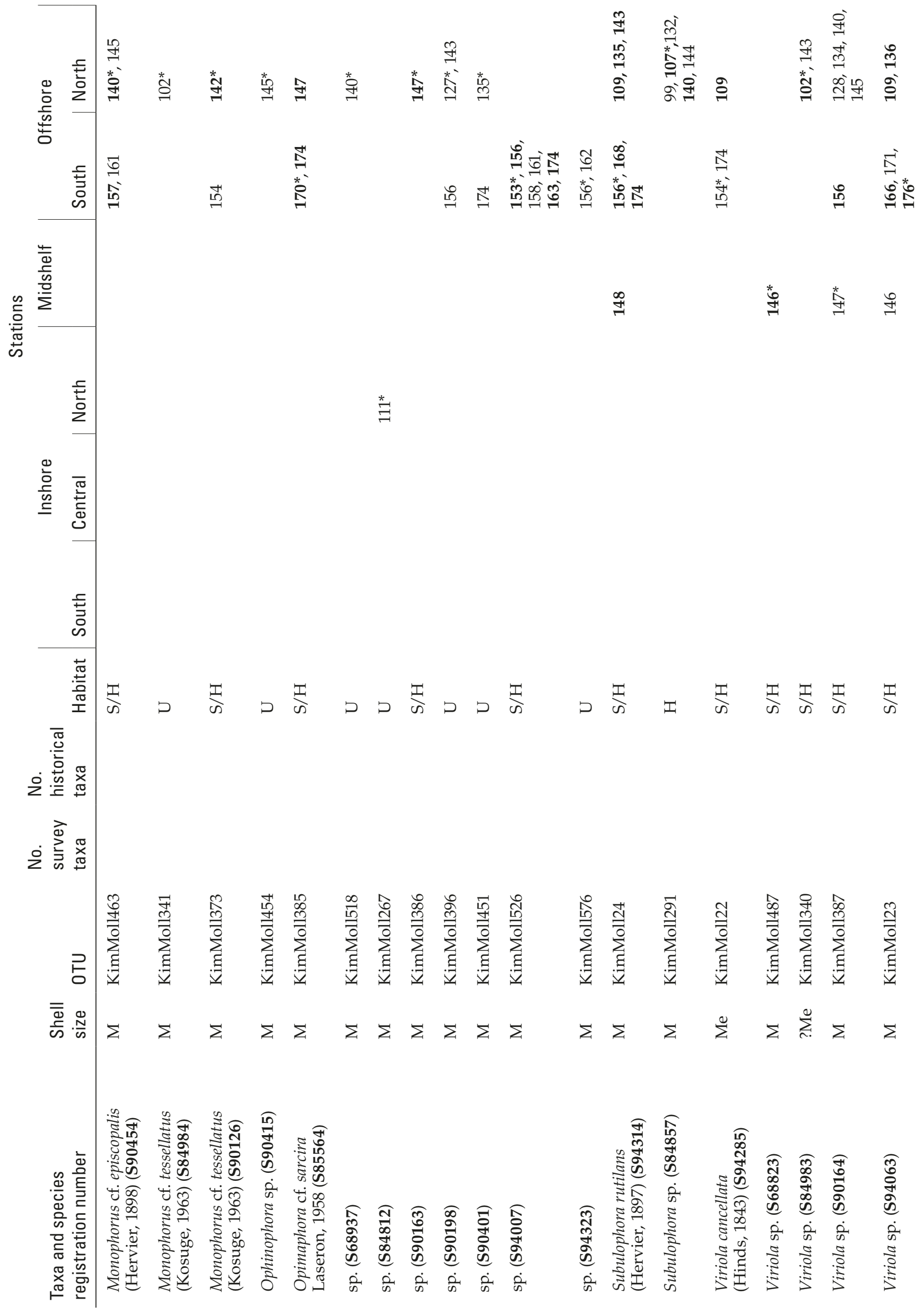




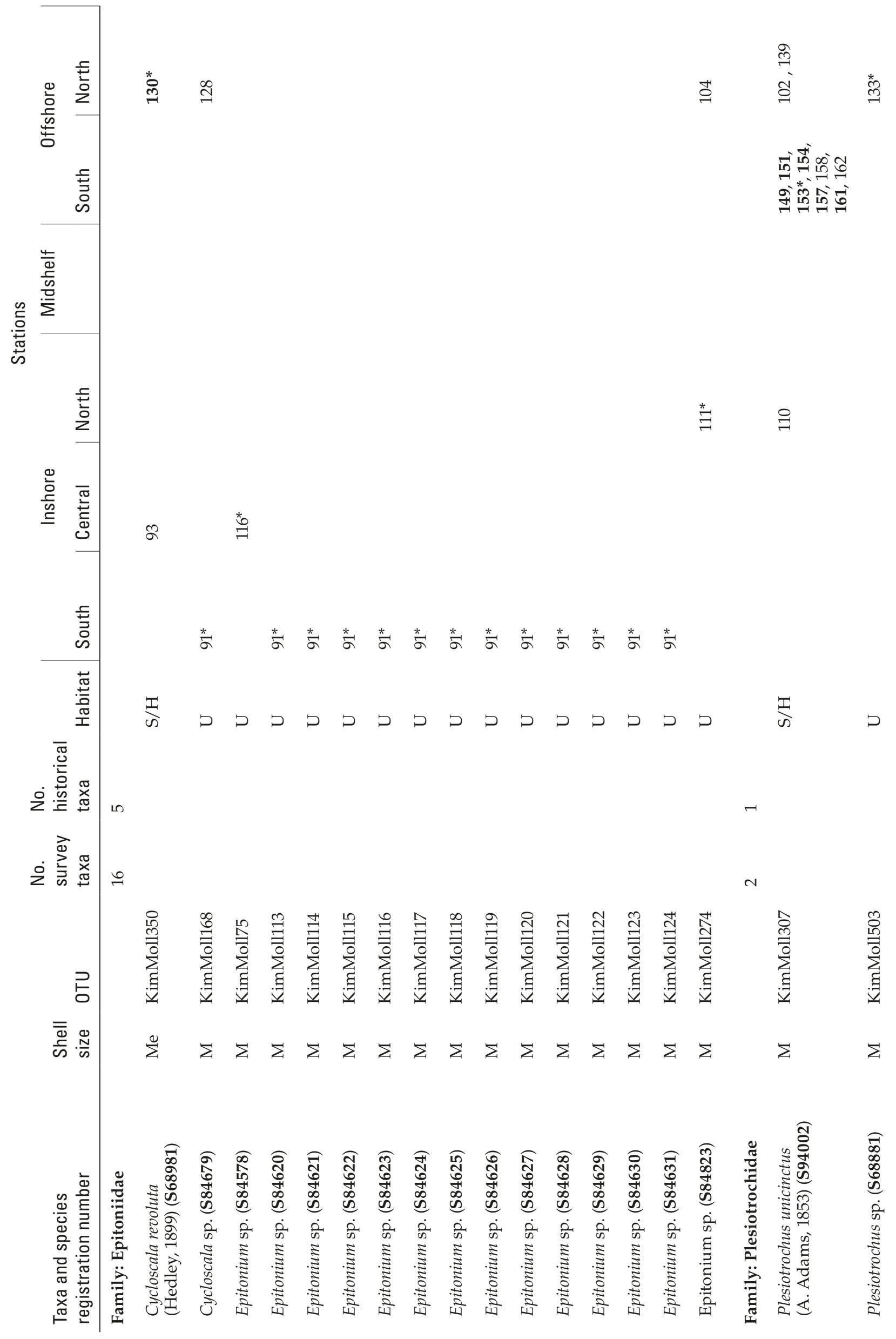




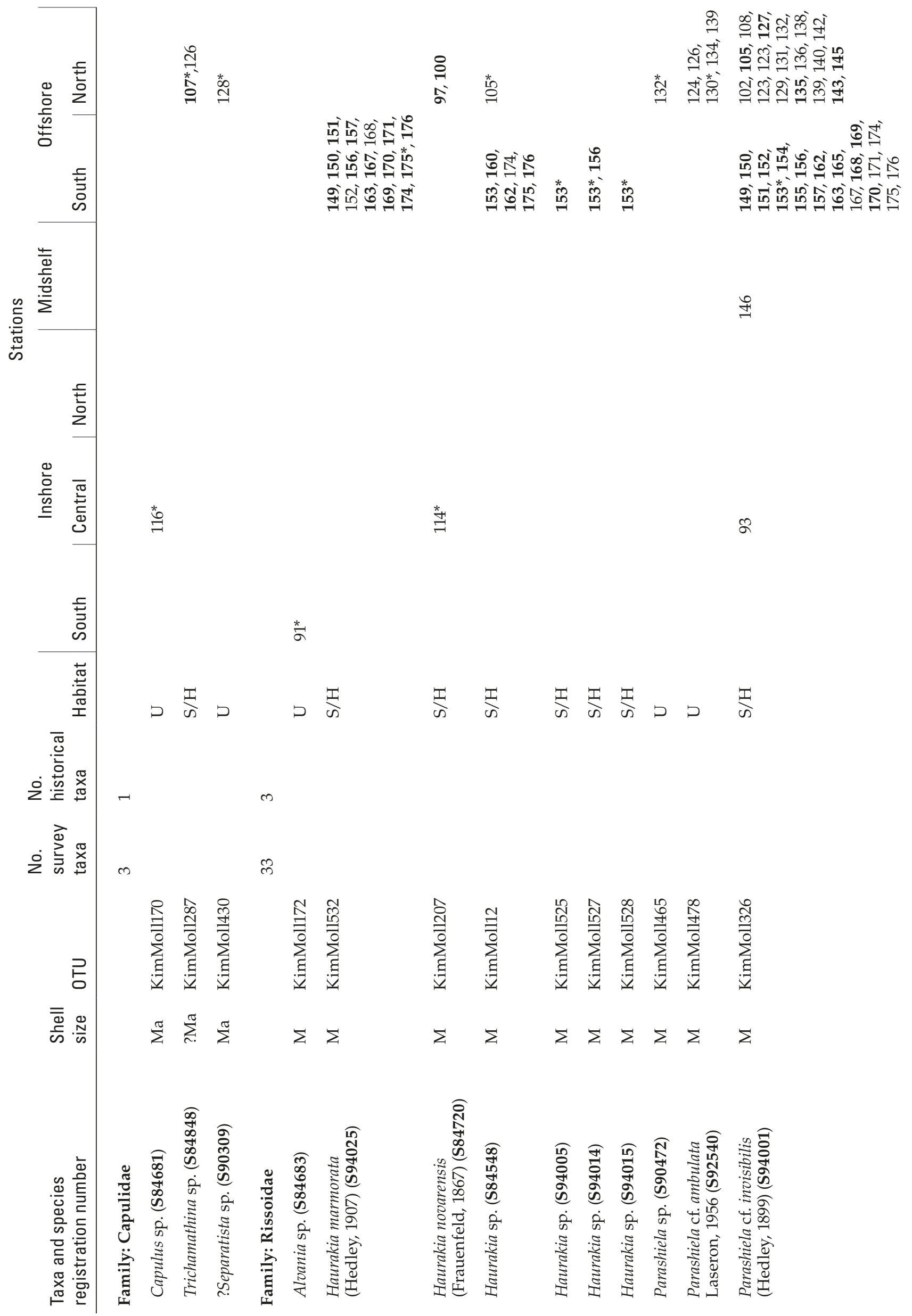




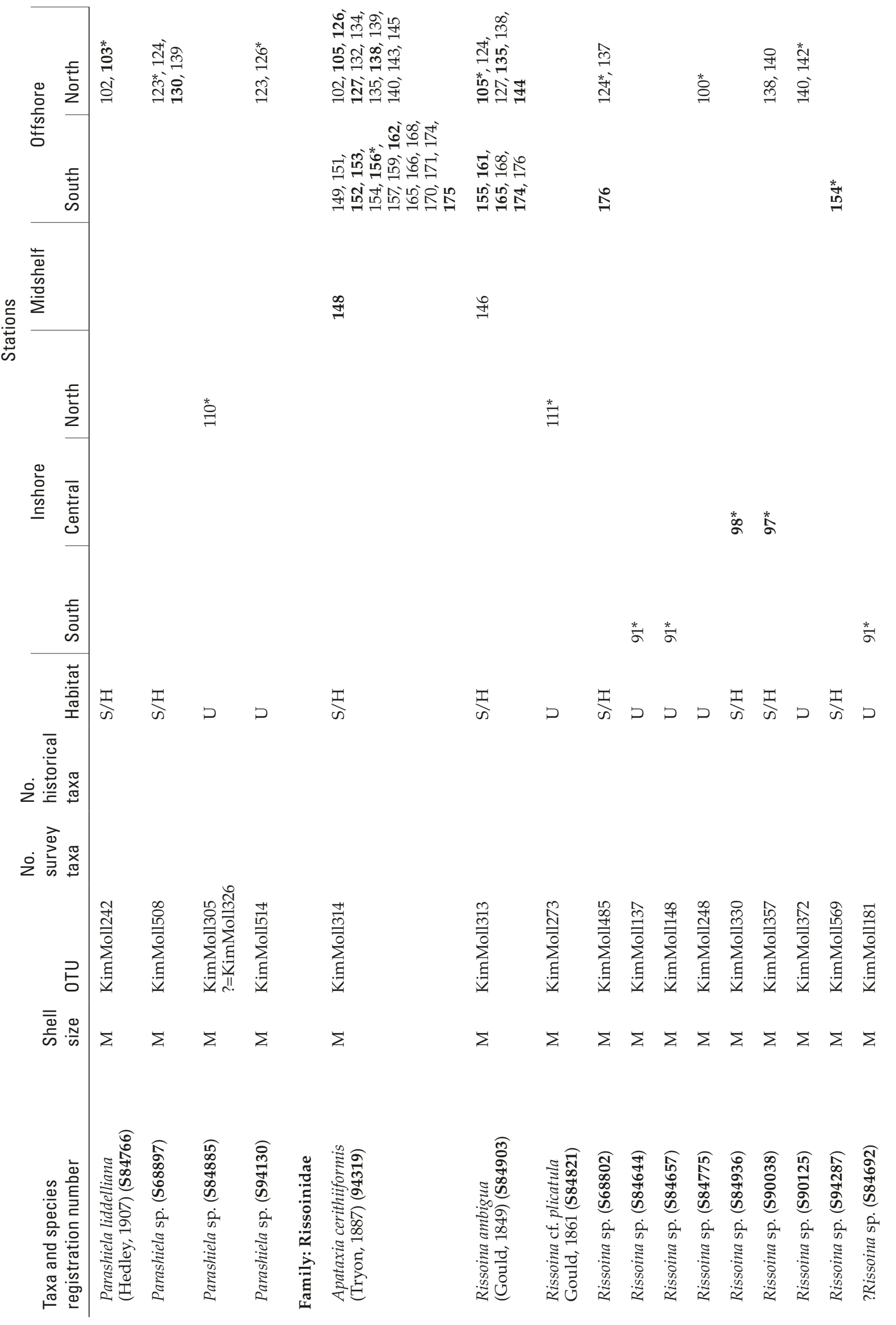




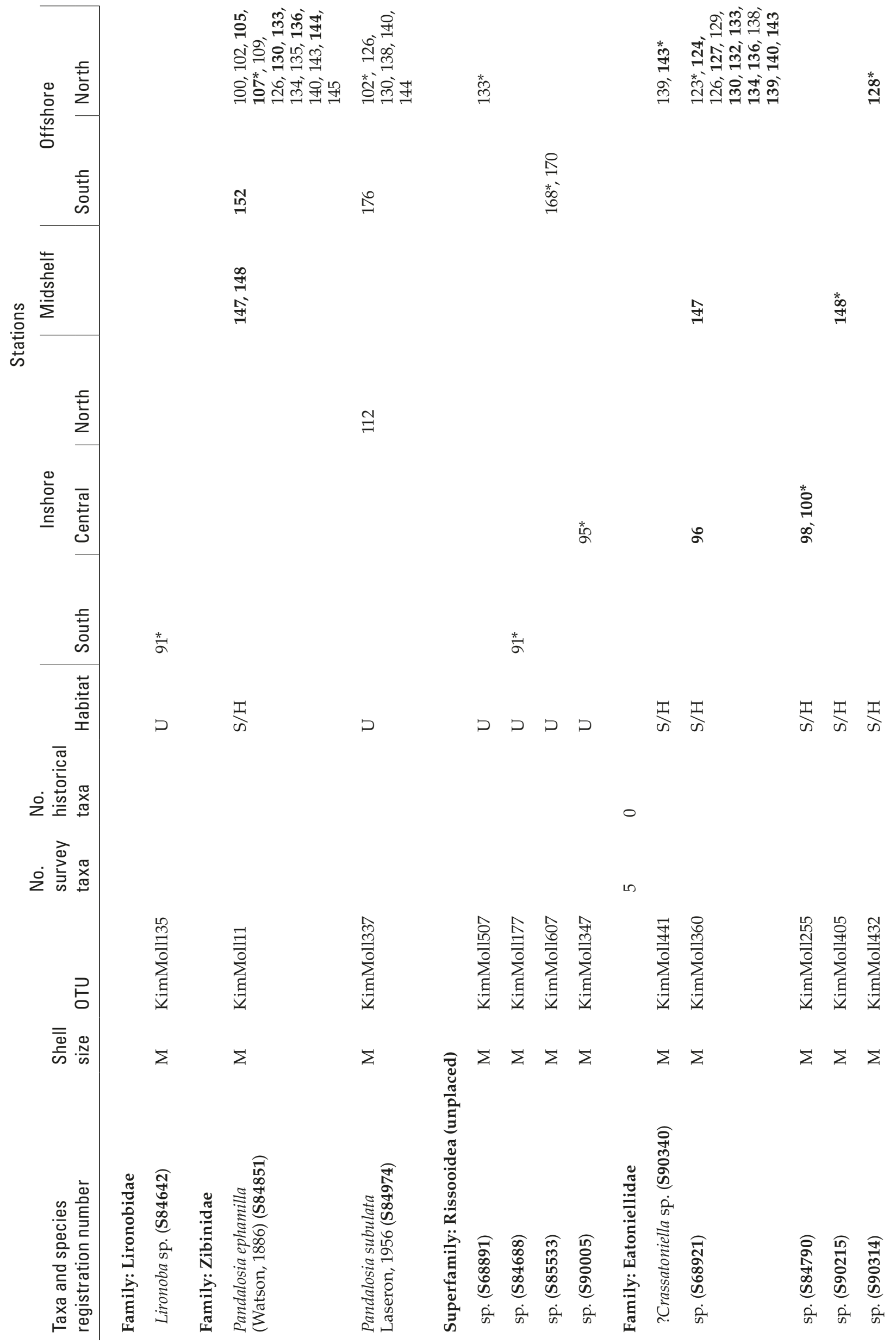




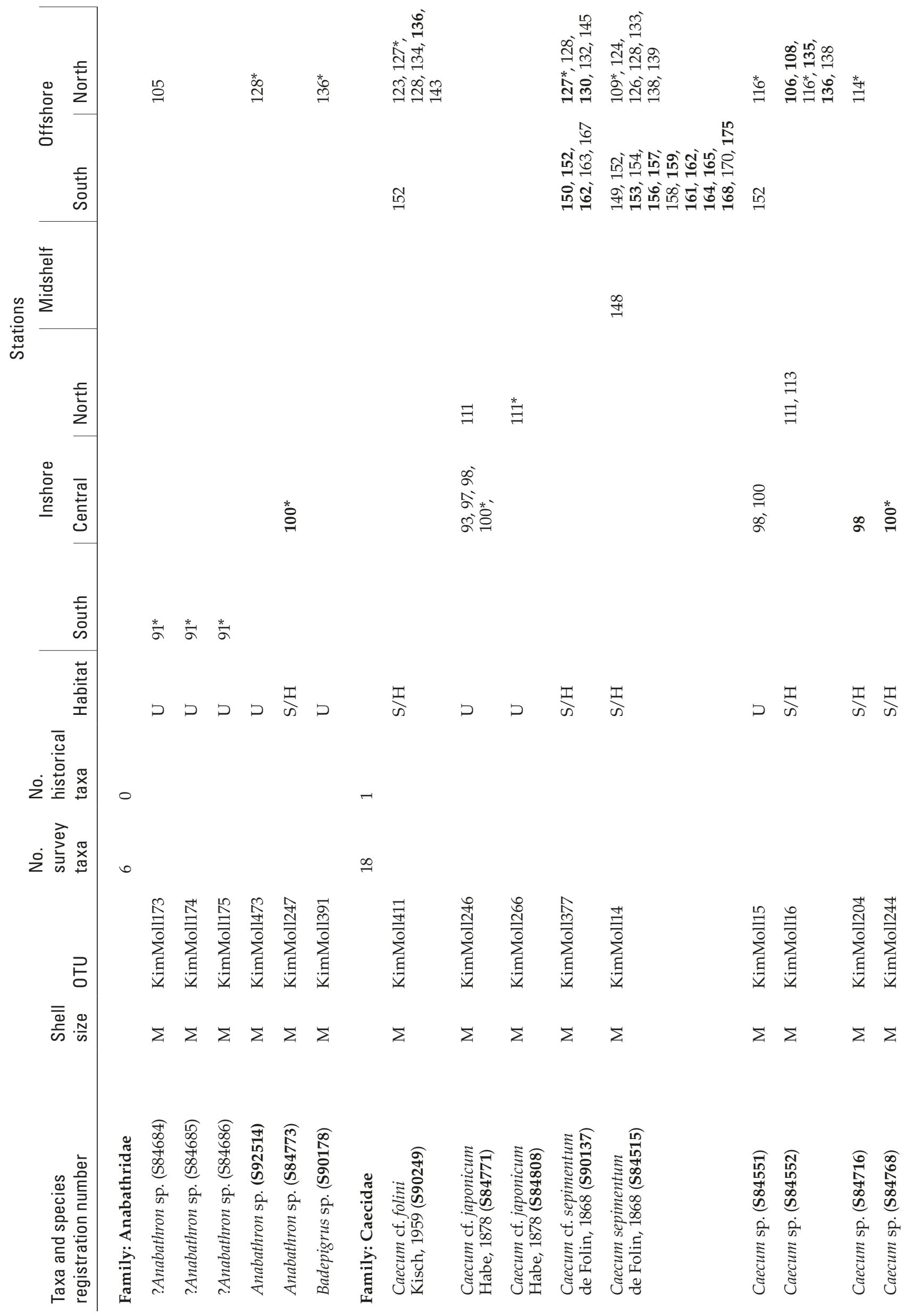




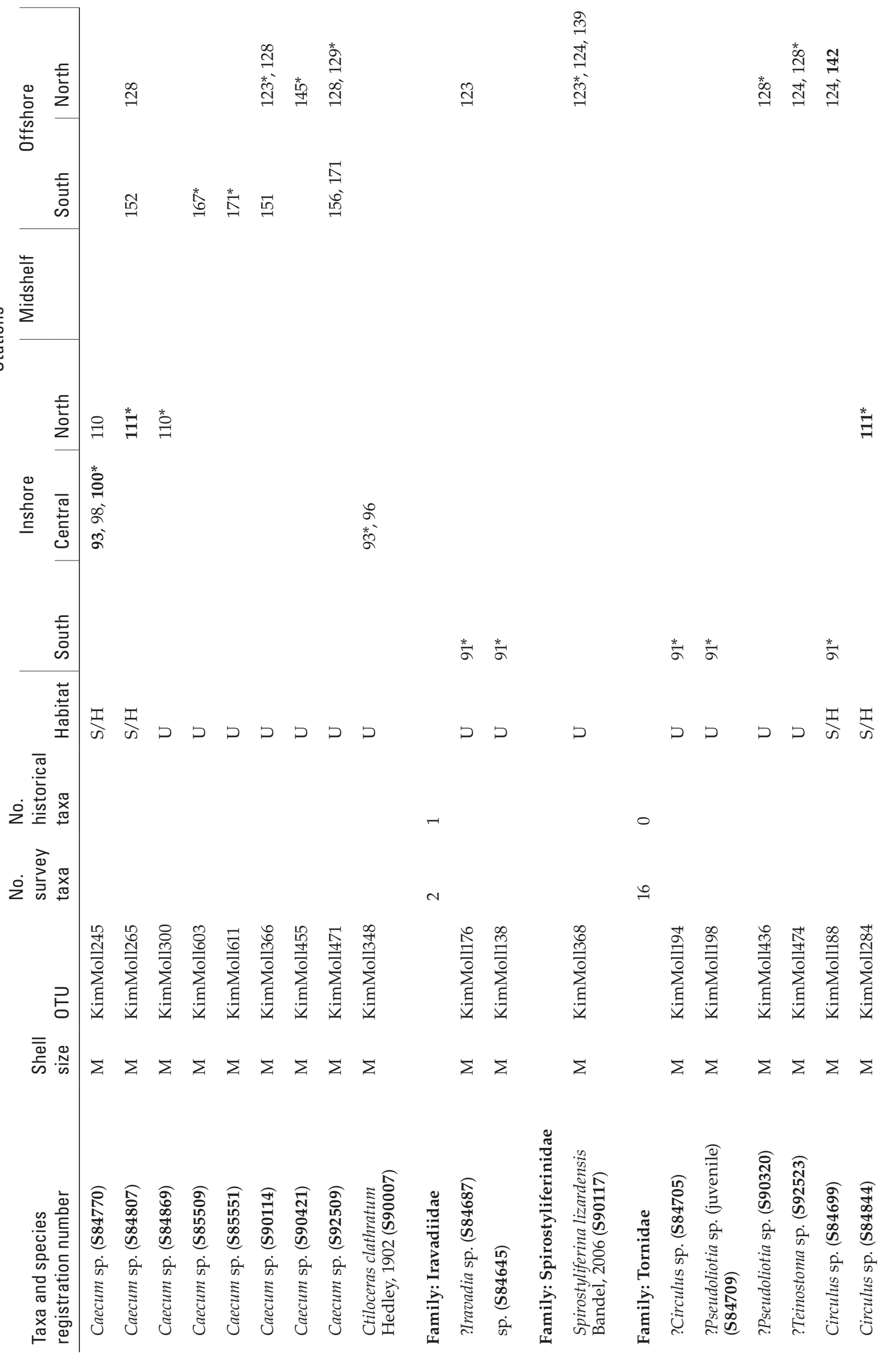




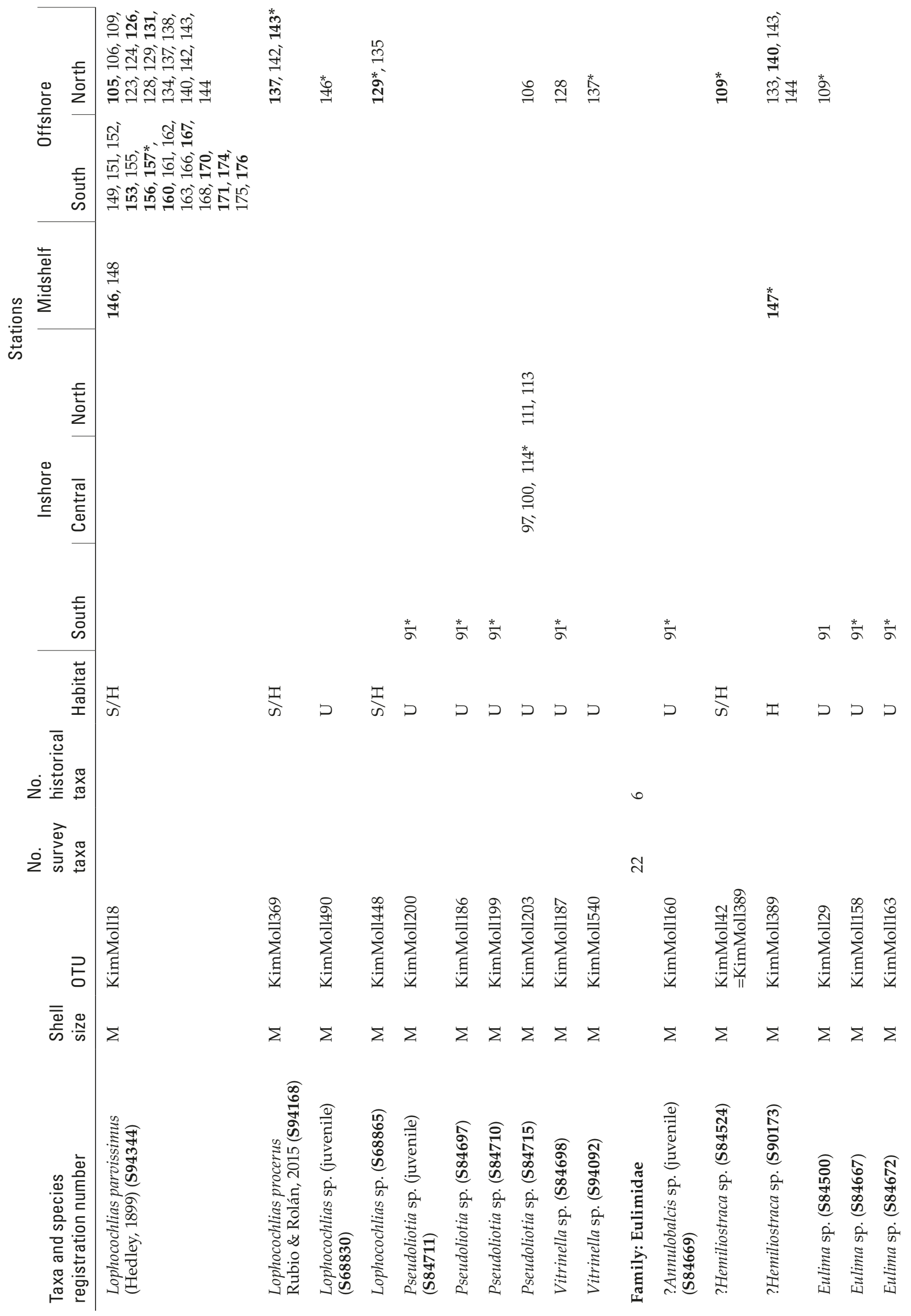




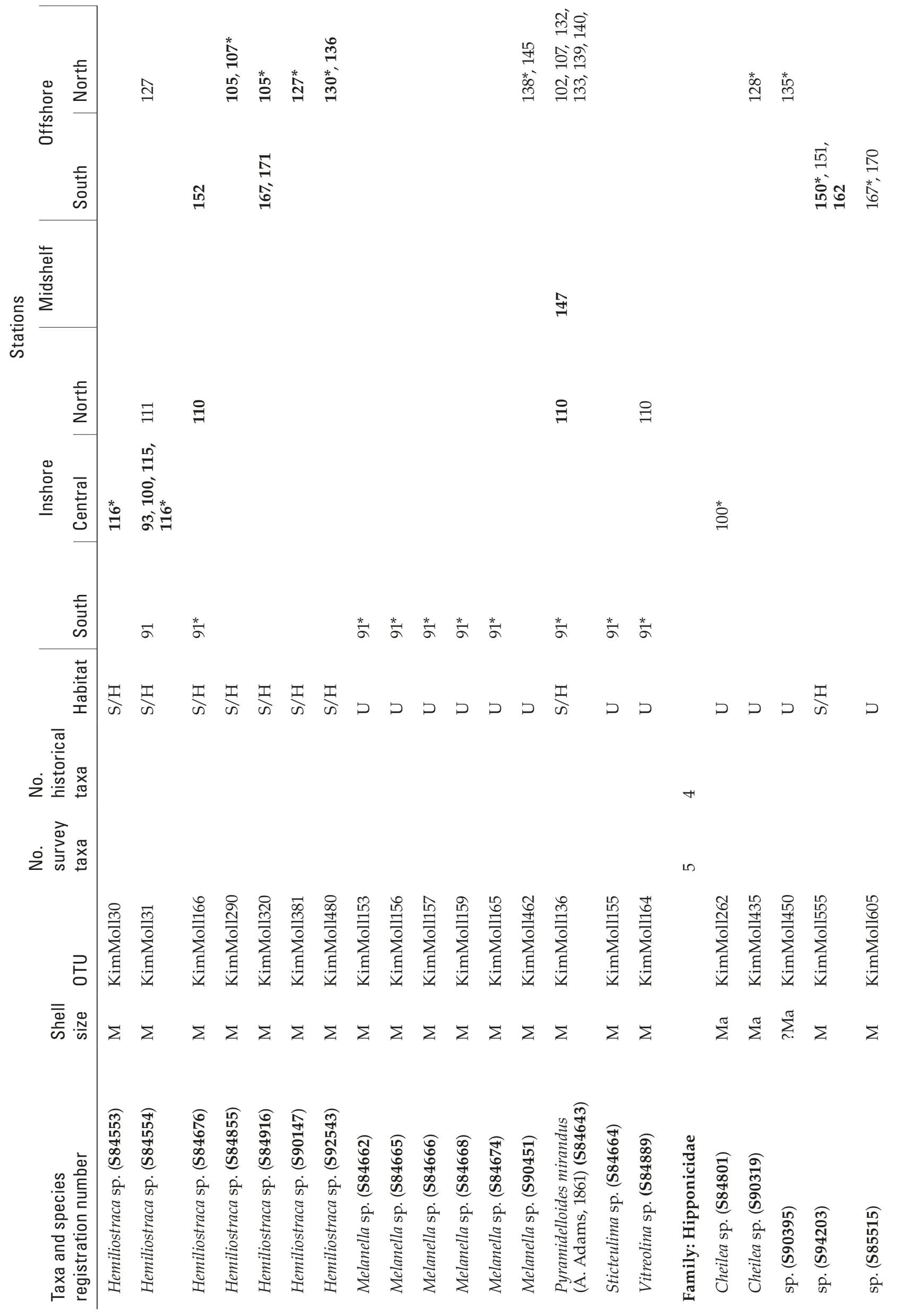




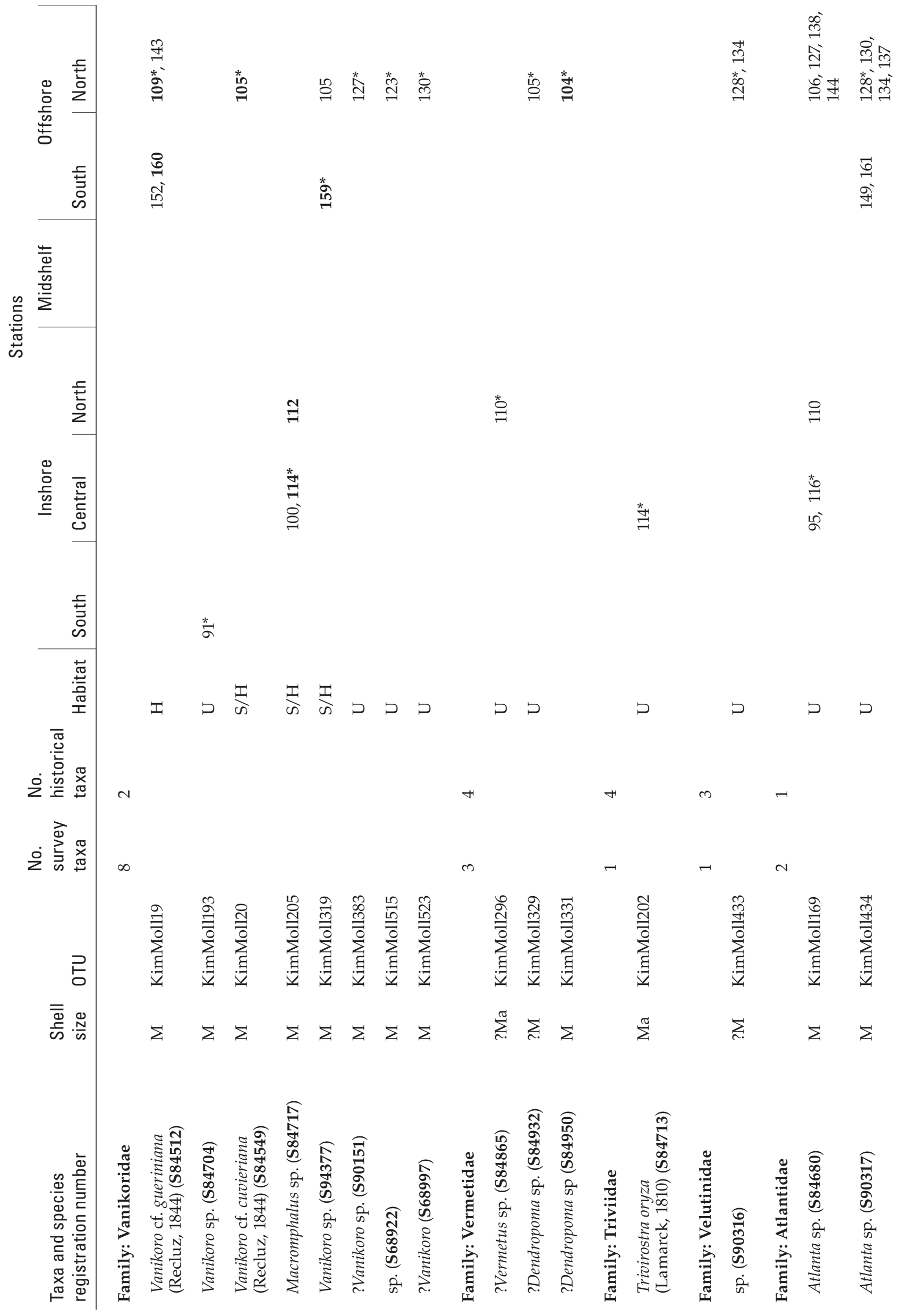




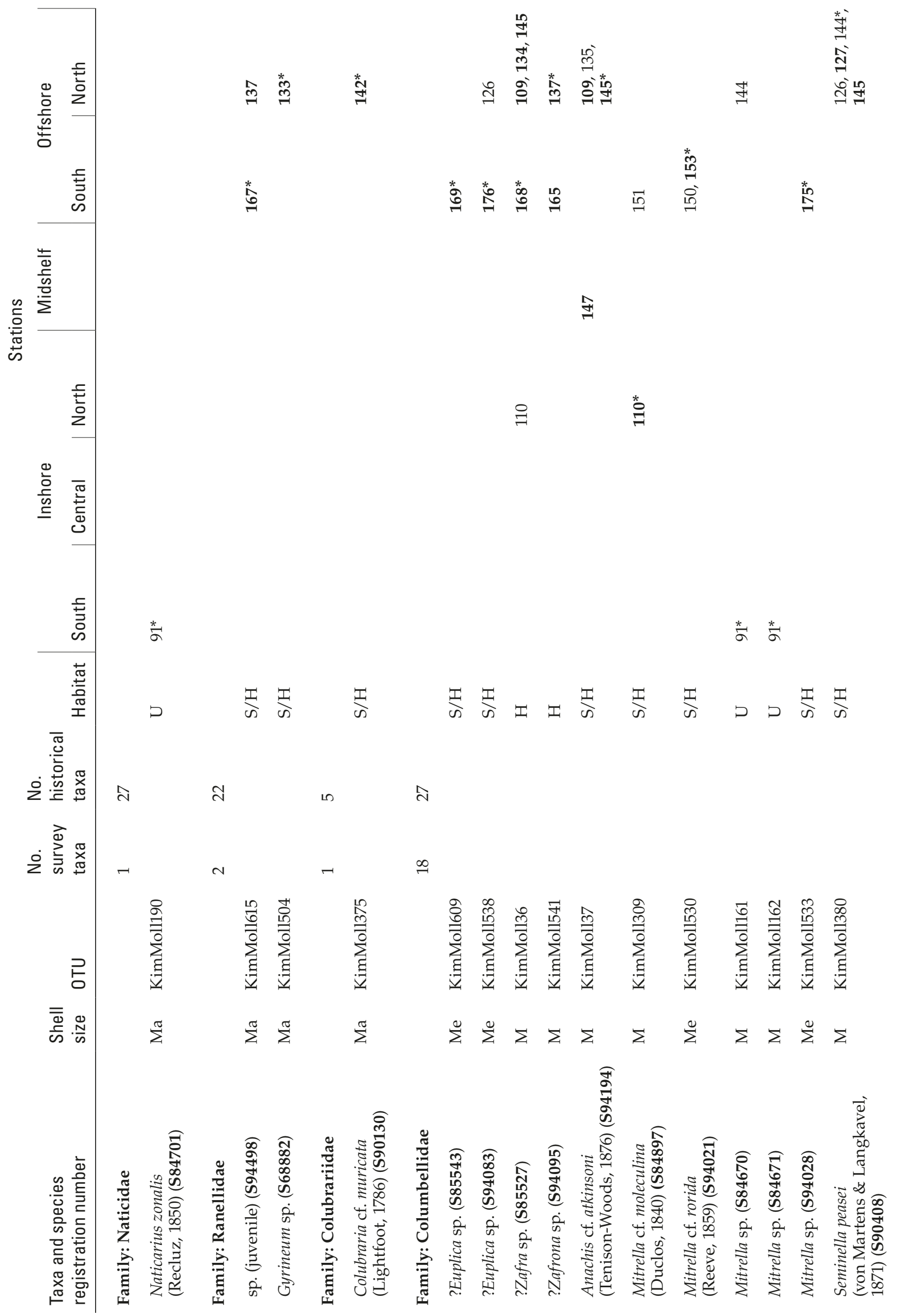




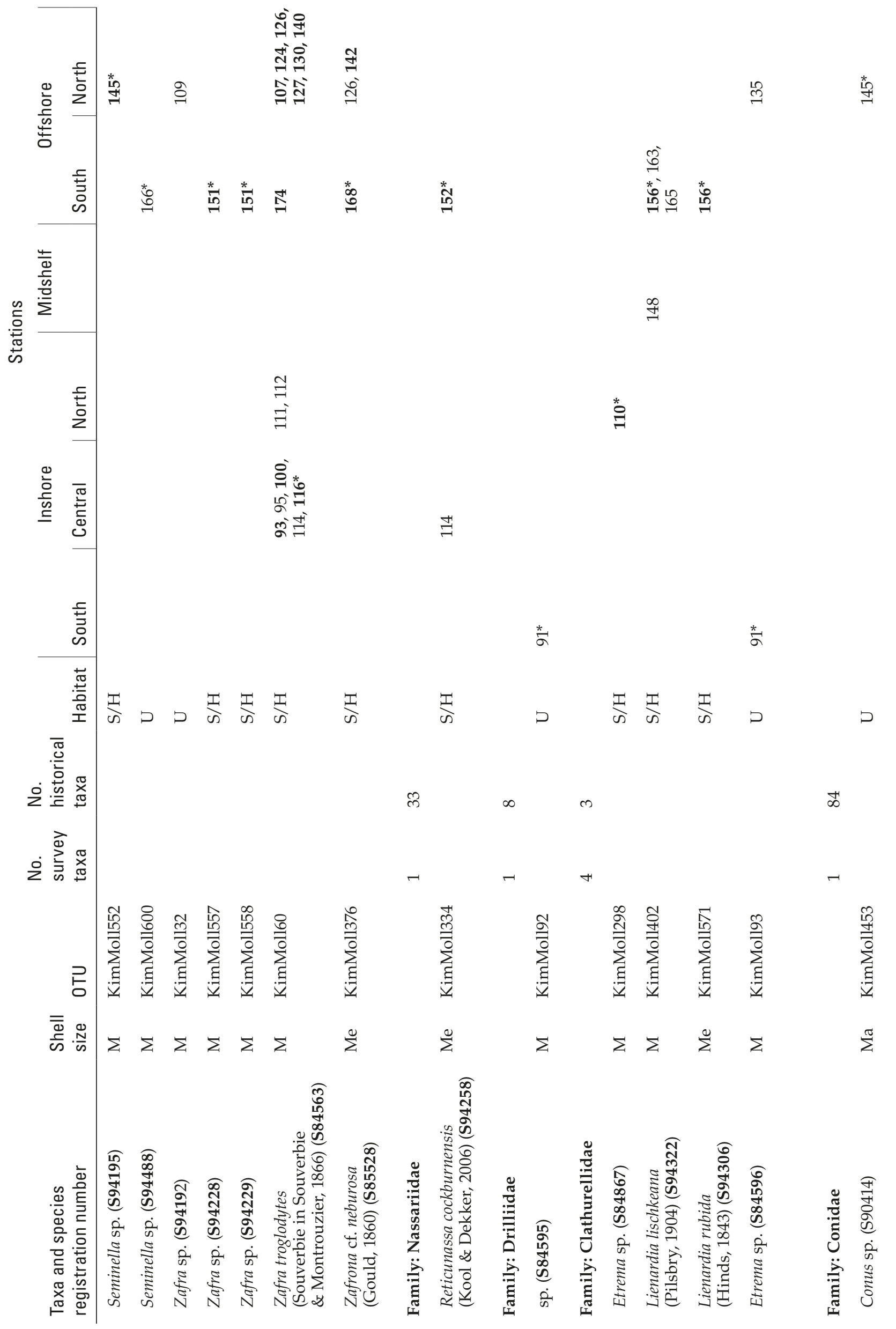




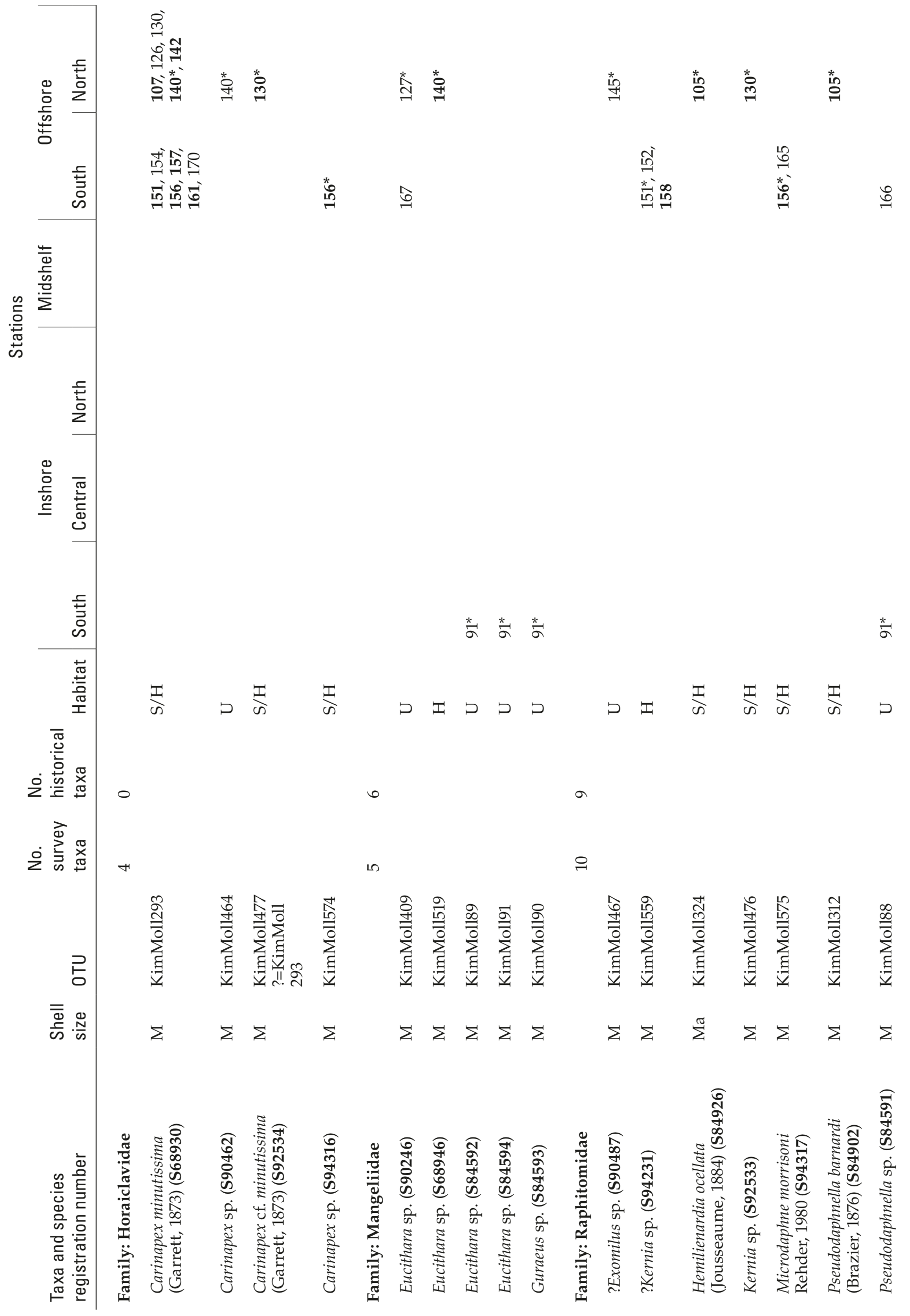




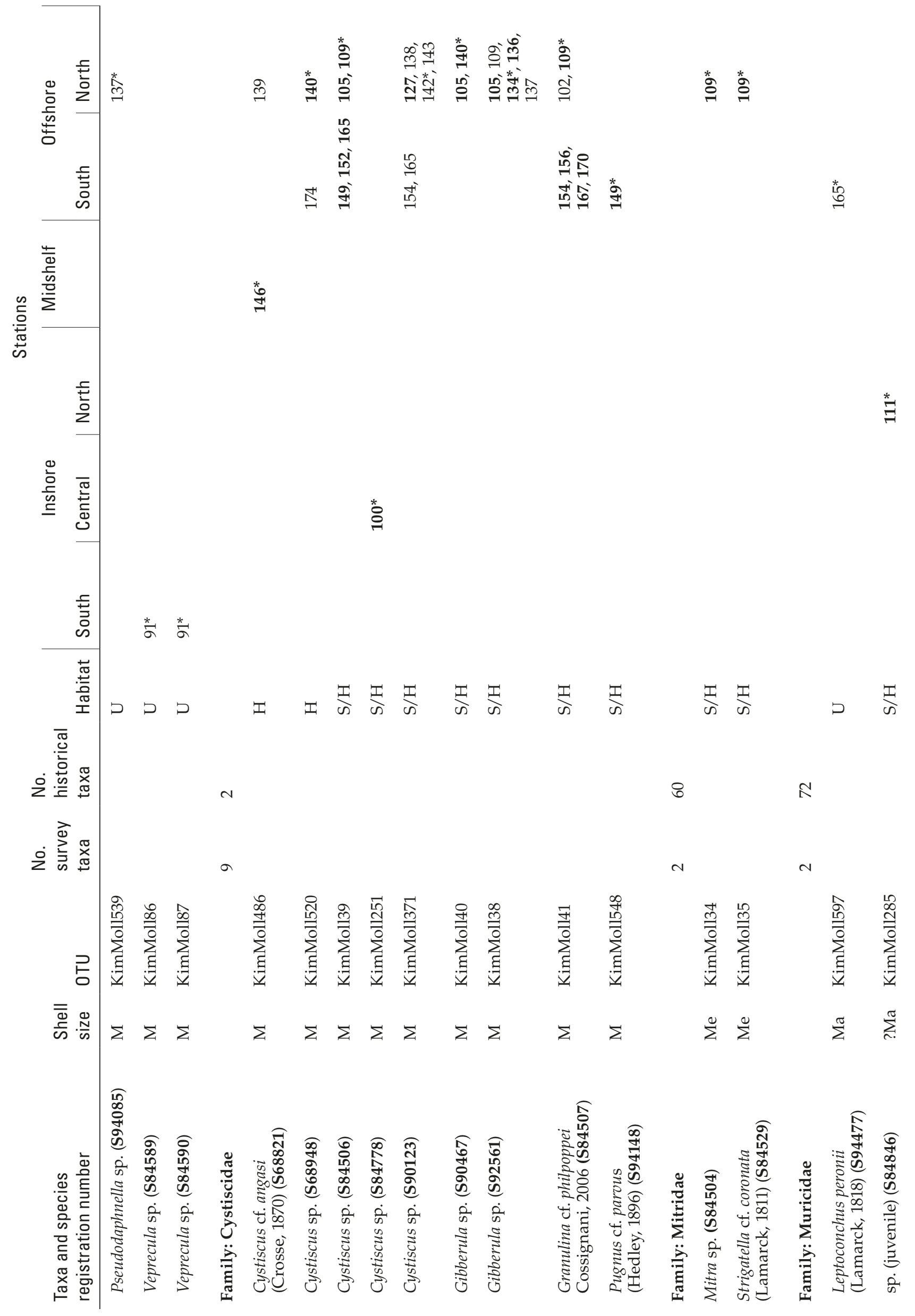




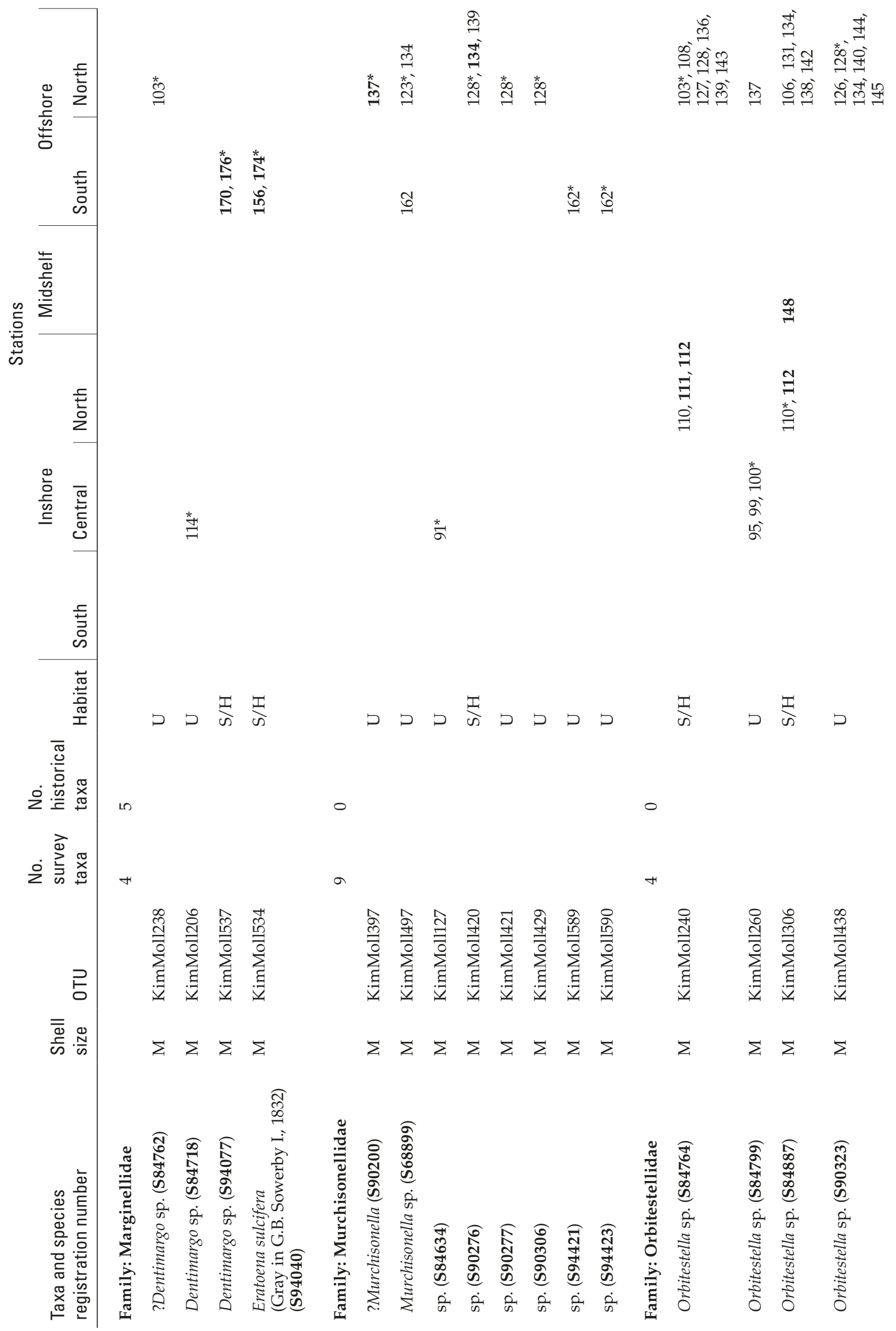




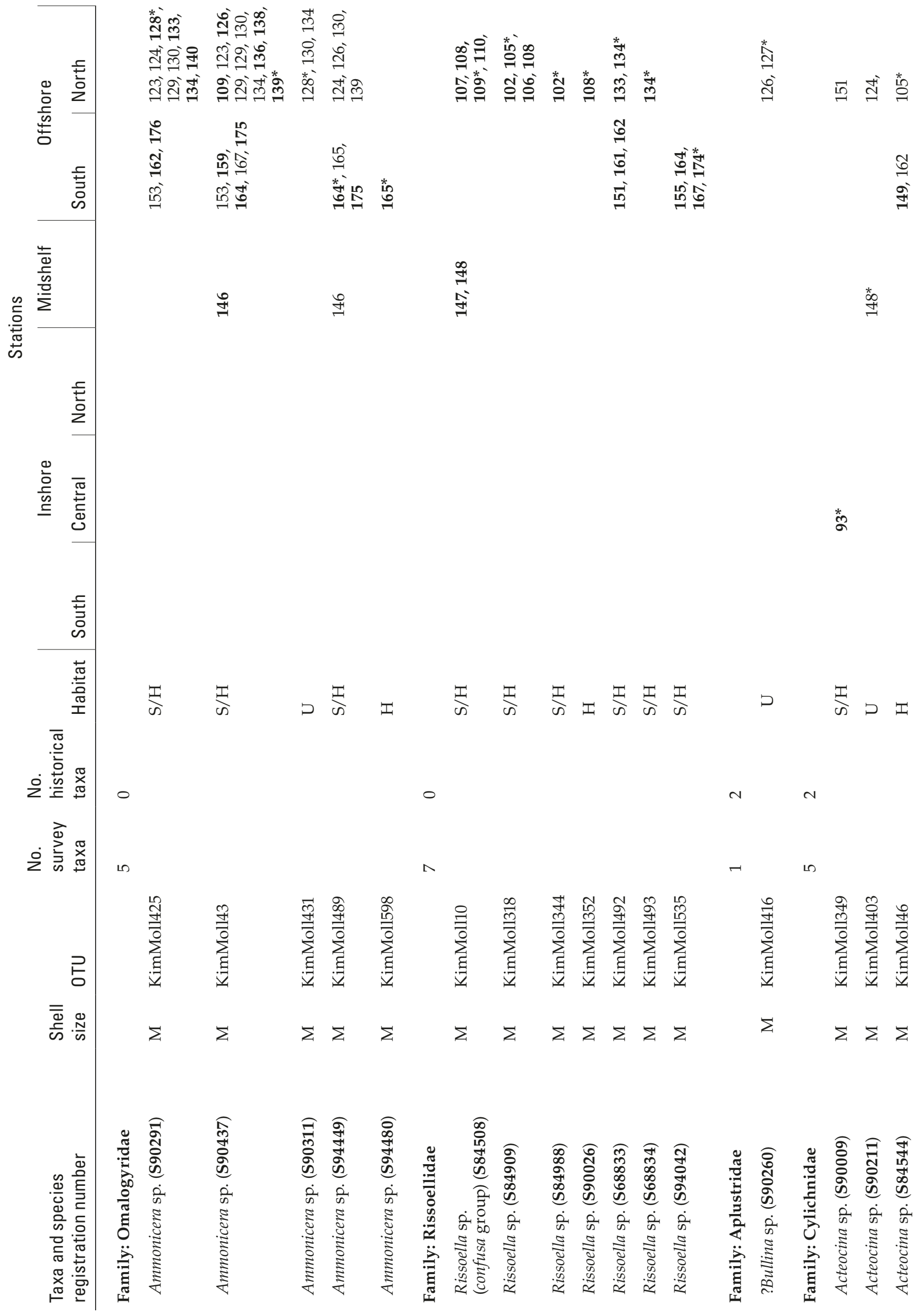




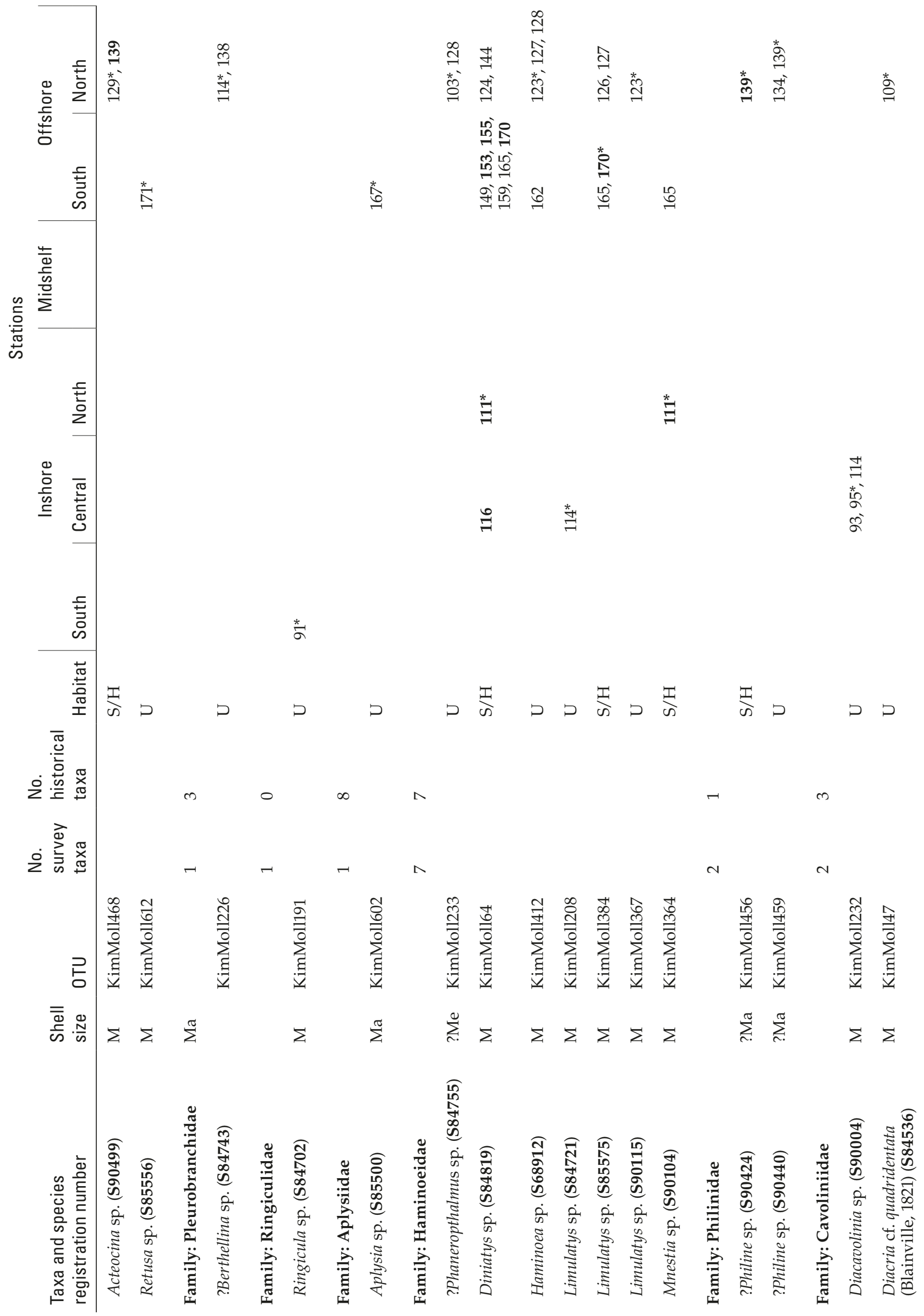




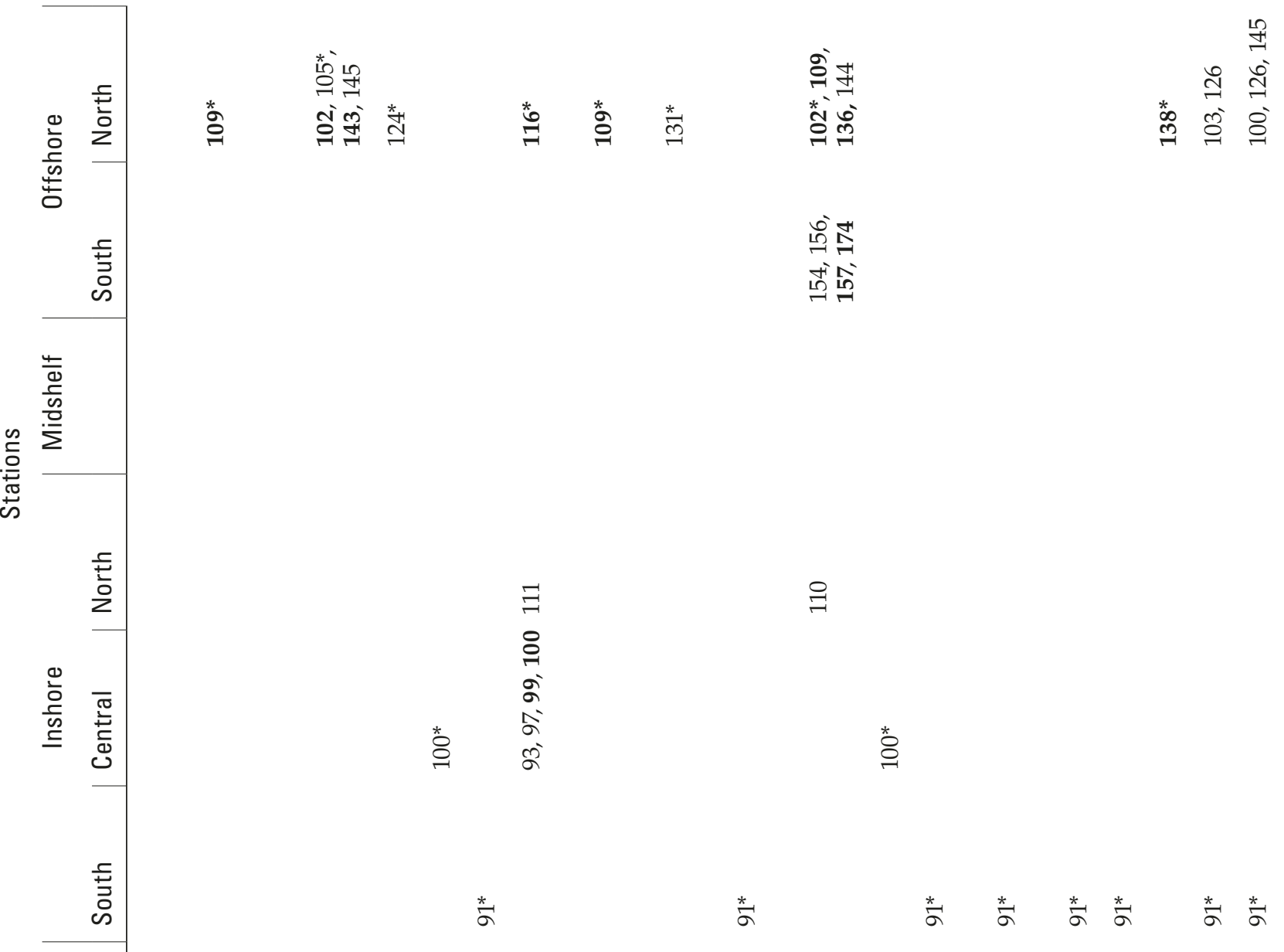

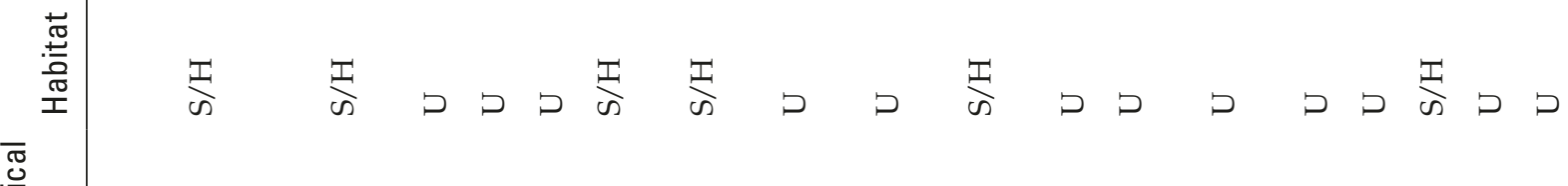

$$
\begin{aligned}
& \overline{\text {. 은 }}
\end{aligned}
$$

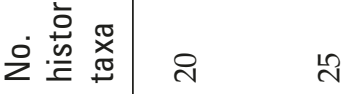

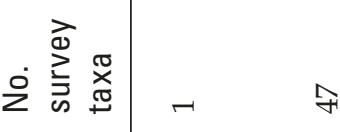

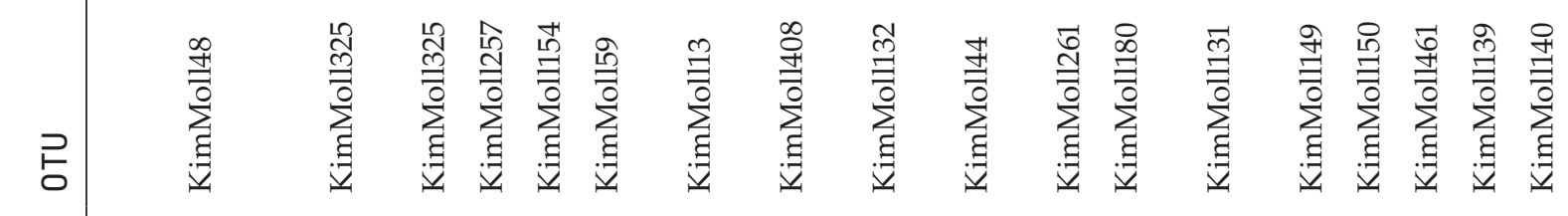

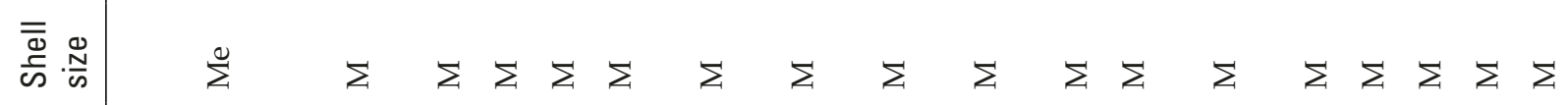

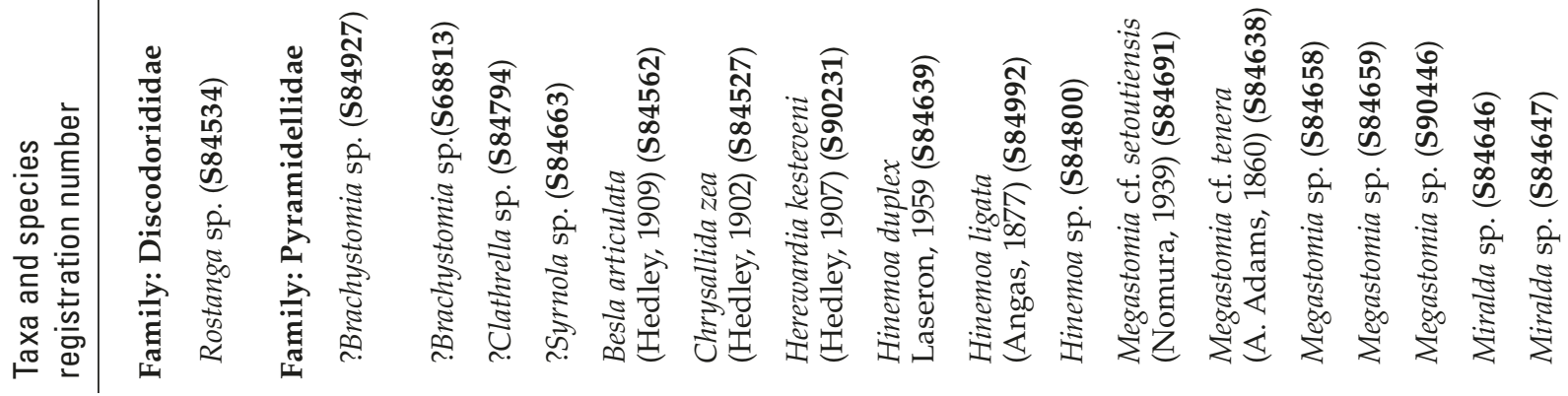




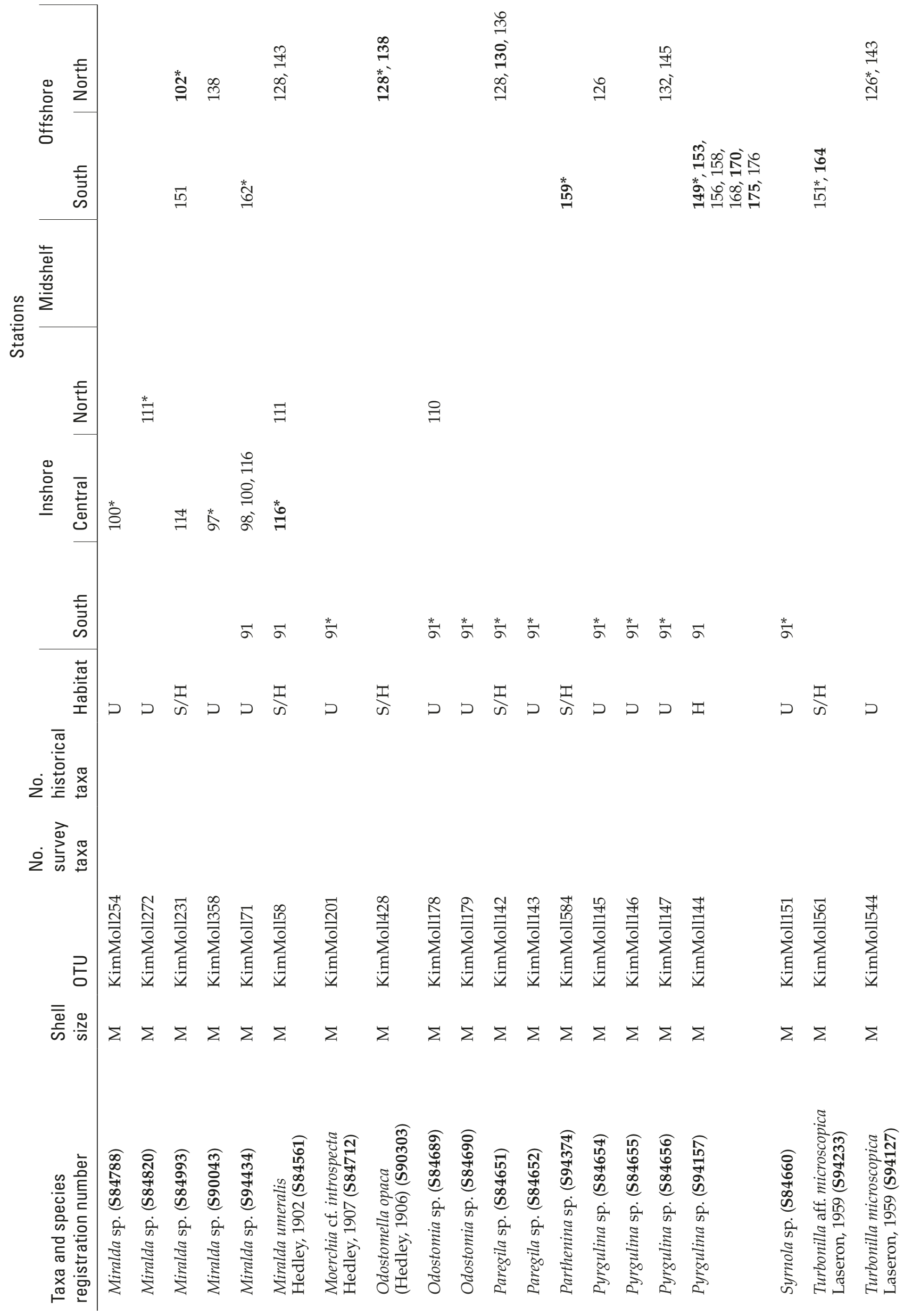




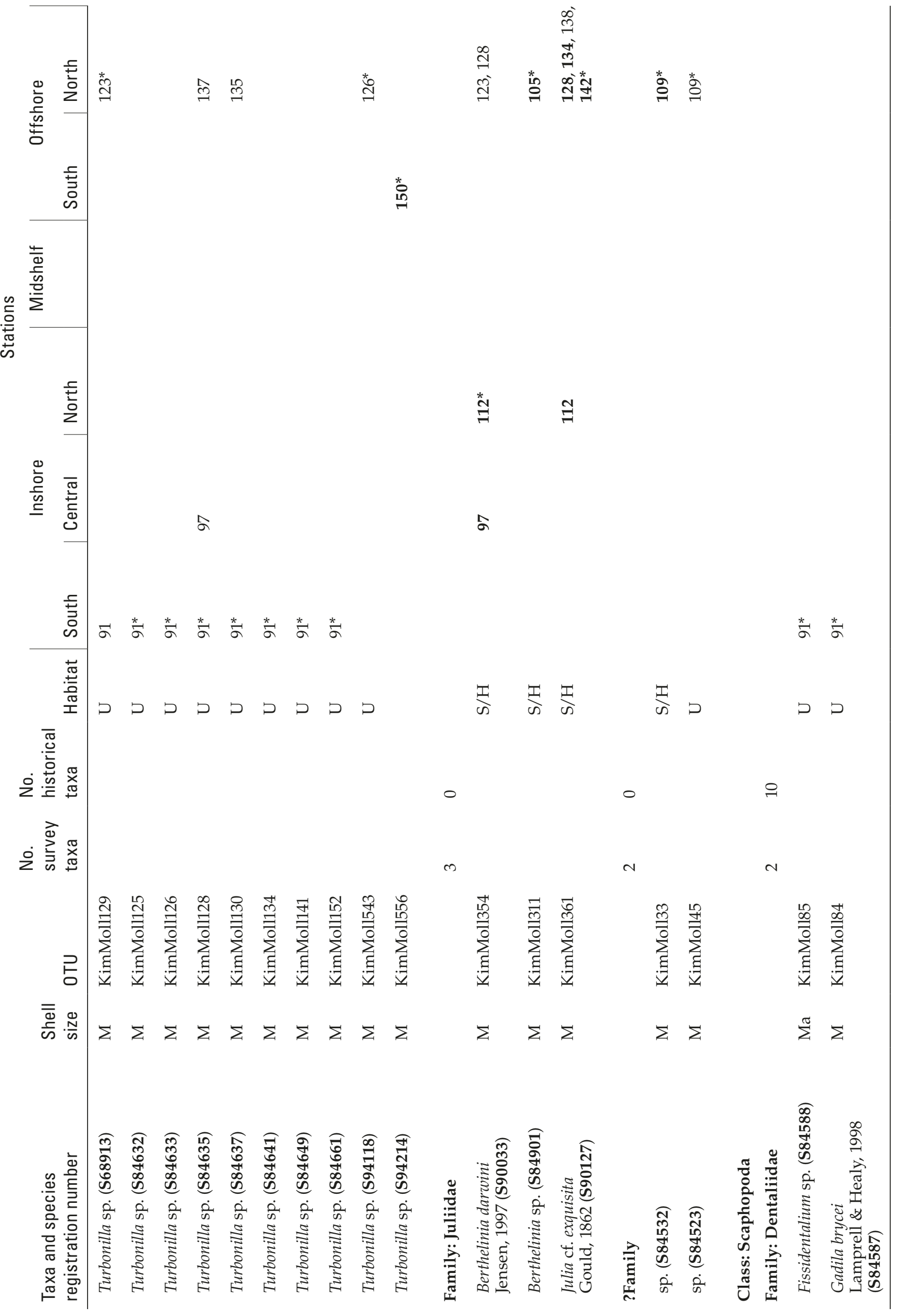




\section{SIGNIFICANT RECORDS AND SPECIES}

The diversity captured in this study includes 102 family or superfamily-level taxa. Twentyone of these familial level taxa were new to the survey area. These and other significant records and species are discussed below to contextualise the findings. Size category data, condition (live or dead) and all references to images are reported in Table 2.

\section{Class Bivalvia}

\section{Subclass Pteriomorphia}

\section{Superfamily Limopsoidea}

\section{Family Philobryidae}

Cosa sp. (KimMoll442, WAM S90346) (Figure 5A) has until now only been recorded from caves in the Ryukyu Islands, Japan, and is still undescribed (see Hayami and Kase 1993: 35, figs 100-102).

\section{Superfamily Pectinoidea}

\section{Family Propeamussidae}

Parvamussium araneum Djikstra, 1991 (KimMoll506, WAM S94109) (M) (Figure 5B) has not previously been recorded from Australia. It is most likely that this discovery represents a new record and not a new species. Parvamussium araneum Djikstra, 1991 was described from Indonesia based on material from 130-300 m depth. The specimen is a juvenile, about $2 \mathrm{~mm}$ maximum diameter, while the size of the Indonesian type material is around $9 \mathrm{~mm}$.

\section{Subclass Heterodonta}

\section{Superfamily Carditoidea}

\section{Family Condylocardiidae}

Condylocuna tricosa Middelfart, 2002 (Figure 5C) was described from Qld and synonymised with Condylocuna io (Barsch, 1915) by Graham and Holmes (2004) despite Middelfart (2002) comparing C. tricosa with the South African type of C. io (United States National Museum (USNM 251043) and stating the dissimilarity. Oliver and Holmes (2004) did not examine the type of C. io, and compared it only to material from Rodrigues Island, which is C. tricosa and not $C$. io. Hence, the synonymy is here revoked and the distribution of C. tricosa is extended across the tropical Indo-Pacific region from Qld to Rodrigues Island and the Kimberley region. Crassacuna sp. (KimMoll230, WAM S84747) (Figure 5D) has not been recorded before (Middelfart 2002b) and is likely new. Crassacuna praecalva (Hedley, 1909)
(KimMoll80, WAM S84583) (Figure 5E) is recorded for the first time in the Kimberley (Middelfart 2002b). Warrana triangulata Middelfart, 2002 was described from single valves from the Joseph Bonaparte Gulf, NT, and its distribution is here extended to WA (Figure 5F). The range of Warrana brucemarshalli Middelfart, 2002 (Figure 5G) is extended from North West Cape to the northern offshore Kimberley.

\section{Superfamily Galeommatoidea}

The illustrated specimen (KimMoll483, WAM S92587) (Figure 5H) is most likely a new genus and species. Mylitta sp. (KimMoll531, WAMS 94062) is the first record of any Mylitta from north-western WA and does not match any described Mylitta from Australia.

\section{Superfamily Veneroidea}

\section{Family Neoleptonidae}

Six species (KimMoll69, WAMS90108 (Figure 6A); KimMoll 83, WAMS84586 (Figure 6B); KimMoll106, WAMS84612 (Figure 6C); KimMoll250, WAMS84777 (Figure 6D); KimMoll426, WAMS90293 (Figure 6E) and KimMoll522, WAMS68990 (Figure 6F) were found and are most likely new species (P. Middelfart, unpublished revision of Australian Neoleptonidae).

\section{Class Gastropoda}

\section{Subclass Vetigastropoda}

\section{Superfamily Trochoidea}

\section{Family Liotiidae}

Bathyliotina schepmani (Habe, 1953) (KimMoll466, WAM S90485) (Figure 6G) from station 145/K13 is the first record of this genus and species from Australia (ALA, AFD).

\section{Family Skeneidae}

Lodderena ornata (Olsson and McGinty, 1958) (KimMoll243, WAM S84767) (Figure 7A) is recorded for the first time in the central Indo-west Pacific Ocean. There is doubt whether the IndoPacific taxon is conspecific with the Atlantic taxon that comprises the type species (Panama, West Indies) (see Lima et al. 2011 and Rubio et al. 1998).

Leucorhynchia caledonica Crosse, 1867 (KimMoll567, WAM S94284) (Figure 7B) and Leucorhynchia tricarinata (Melvill and Standen, 1896) (KimMoll579, WAM S94333) (Figure 7C) are both new records for WA. 


\section{Family Trochidae}

Alcyna ocellata A. Adams, 1860 (KimMoll370, WAM S90121) (Figure 7D) is recorded for the first time from Australia (ALA).

\section{Subclass Caenogastropoda \\ Superfamily Triphoroidea \\ Family Triphoridae}

Three OTUs are considered to be related to the corresponding species:

OTU KimMoll581, (WAM S94346) (Figure 7E) aligns with Mastonia lamberti (Hervier, 1898).

OTU KimMoll341, (WAM S84984) (Figure 7F) aligns with Monophorus tessellatus (Kosuge, 1963).

OTU KimMoll388, (WAM S90168) (Figure 7G) aligns with Monophorus atratus (Kosuge, 1962).

These are new records for WA.

\section{Family Cerithiopsidae}

Paraseila sp. (KimMoll572, WAM S94307) (Figure $7 \mathrm{H})$ is the first record of the genus in WA. There are only three species of this genus recorded from Australia (ALA, AFD), with records from New South Wales (NSW), Qld and Tasmania.

\section{Superfamily Epitonioidea}

\section{Family Epitoniidae}

Cycloscala revoluta (Hedley, 1899) (KimMoll350, WAM S68981) (Figure 8A) is a new record for WA, although it is known from the Indo-west Pacific Ocean.

\section{Superfamily Rissoidea}

\section{Families Rissoidae and Rissoinidae}

Haurakia marmorata (Hedley, 1907) (KimMoll532, WAM S94025) (Figure 8B) and Parashiela liddelliana (Hedley, 1907) (KimMoll242, WAM S84766) (Figure $8 \mathrm{C})$ are new records for WA.

\section{Superfamily Capuloidea \\ Family Capulidae}

Trichamathina sp. (KimMoll287, WAM S84848) (Figure $8 \mathrm{D}$ ) is a new record for Australia (AFD, ALA).

\section{Subclass Heterobranchia}

\section{Superfamily Orbitestelloidea \\ Family Orbitestellidae}

Four Orbitestella spp. were found in the survey area, all of which are new species, viz., Orbitestella sp. (KimMoll240, S84764) (Figure 8E), Orbitestella sp. (KimMoll260, S84799) (Figure 8F), Orbitestella sp. (KimMoll306, WAM S84887) (Figure 8G) and Orbitestella sp. (KimMoll438, WAM S90323) (Figure $8 \mathrm{H}$ ).

\section{Superfamily Omalogyroidea \\ Family Omalogyridae}

Five species of Ammonicera (KimMoll43, WAM S90437 (Figure 9H); KimMoll425, WAM S90291 (Figure 9I); KimMoll431, WAM S90311 (Figure 9J); KimMoll489, WAM S94449 (Figure 9K); KimMoll598, WAM S94480 (Figure 9L) were found in this study and all are new species.

\section{Superfamily Rissoelloidea \\ Family Rissoellidae}

Previously no species of this family had been reported from Exmouth to the NT border. However, at least seven new species were found in this study including Rissoella sp. (confusa group) (KimMoll10, WAM S84508) (Figure 9A), Rissoella sp. (KimMoll318, WAM S84909) (Figure 9B), Rissoella sp. (KimMoll344, WAM S84988) (Figure 9C), Rissoella sp. (KimMoll352, WAM S90026) (Figure 9D), Rissoella sp. (KimMoll492, S68833) (Figure 9E), Rissoella sp. (KimMoll493, WAM S68834) (Figure 9F) and Rissoella sp. (KimMoll535, WAM S94042) (Figure 9G).

\section{Superfamily Pyramidelloidea \\ Family Pyramidellidae}

Chrysallida zea (Hedley, 1902) (KimMoll13, WAM S84527) (Figure 9N), Herewardia kesteveni (Hedley, 1907) (KimMoll408, WAM S90231) (Figure 9O), Odostomella opaca (Hedley, 1906) (KimMoll428, WAM S90303) (Figure 9P), Turbonilla microscopica Laseron, 1959 (KimMoll561, WAM S94233) (Figure 9Q) and Besla articulata (Hedley, 1909) (KimMoll59, WAM S84562) (Figure 9R) are all new records for WA. The OTU KimMoll201 (WAM S84712) (Figure 9M) aligns with Morchia introspecta (Hedley, 1907), which has not previously been recorded from Australia. 


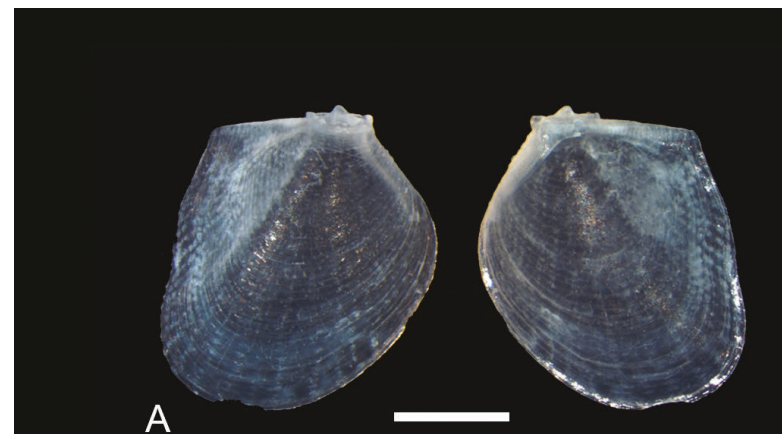

A
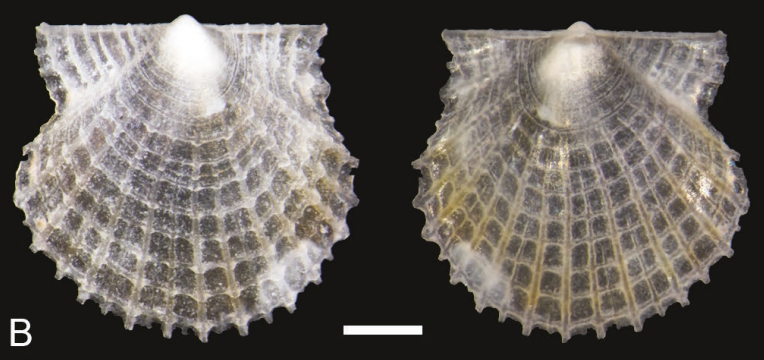

C
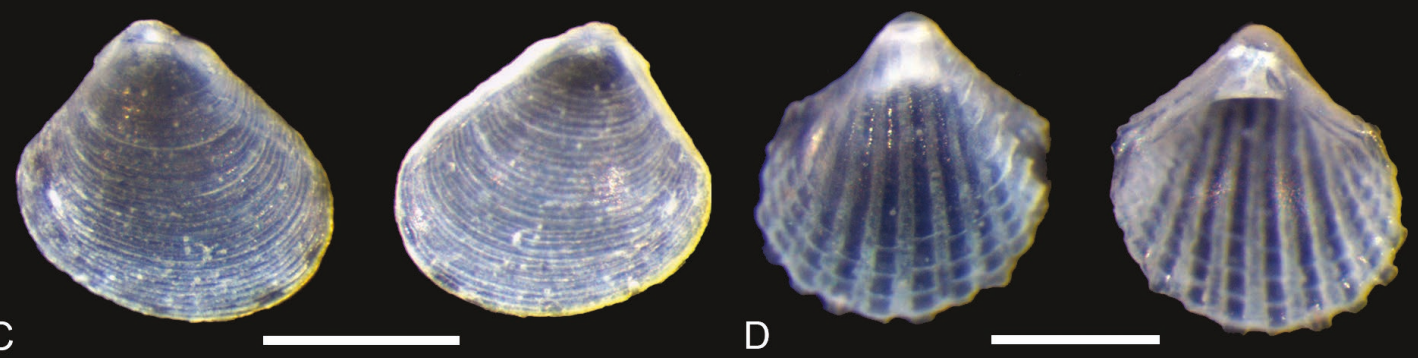

E
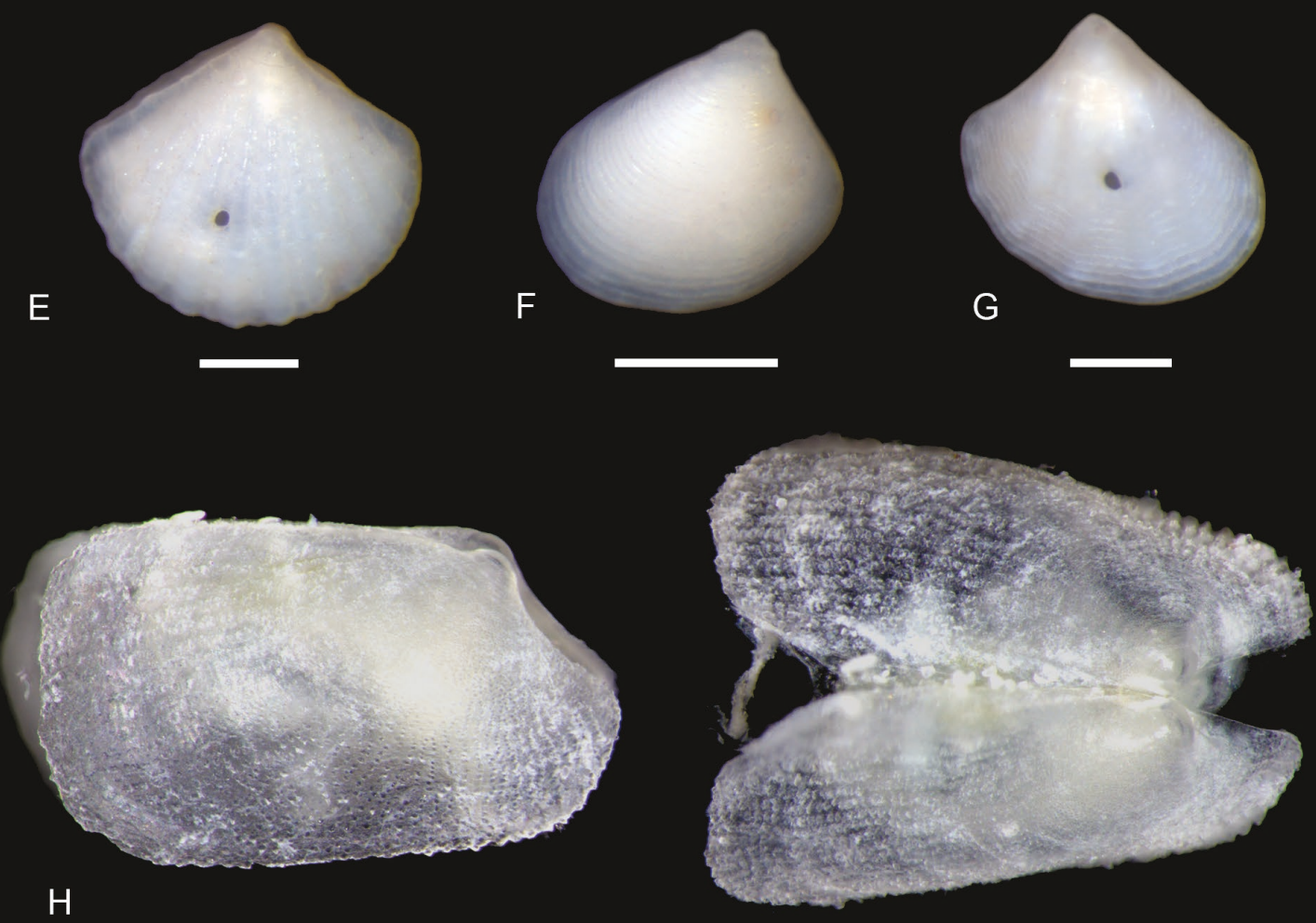

$\mathrm{H}$

FIGURE 5 New species and records. A) Cosa sp. (KimMoll442, WAM S90346), new species; B) Parvamussium cf. araneum Djikstra, 1991 (KimMoll506, WAM S94109), new record Australia; C) Condylocuna tricosa Middelfart, 2002 (KimMoll310, WAM S84900), new record WA; D) Crassacuna sp. (KimMoll230, WAM S84747), new species; E) Crassacuna praecalva (Hedley, 1909) (KimMoll80, WAM S84583), new record in survey area; F) Warrana triangulata Middelfart, 2002b (KimMoll100, WAM S84604), new WA record;

G) Warrana brucemarshalli Middelfart, 2002b (KimMoll76, WAM S84579), new record for Project Area;

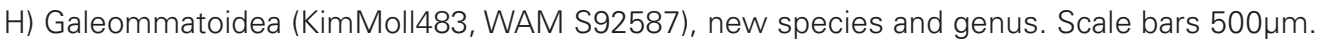




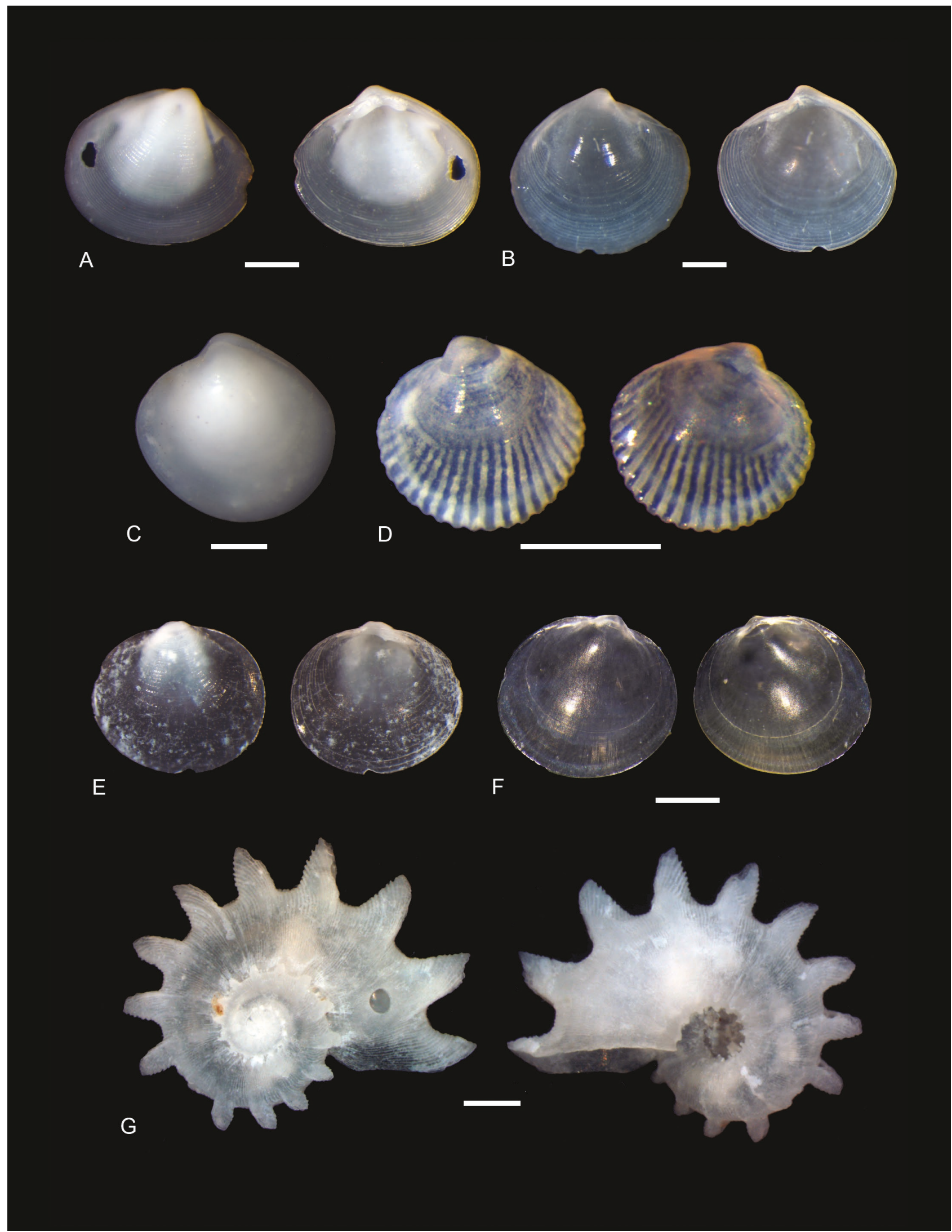

FIGURE $6 \quad$ New species and records. A) Neolepton sp. (KimMoll69, WAM S90108), new species; B) ?Neoleptonidae (KimMoll83, WAM S84586), unknown species; C) ?Micropolia sp. (KimMoll106, WAM S84612), new species; D) ?Neoleptonidae (KimMoll250, WAM S84777), unknown species and genus; E) Neolepton sp. (KimMoll426, WAM S90293), new species, no scale; F) ?Micropolia sp. (KimMoll522, WAMS68990), unknown species; G) Bathyliotina schepmani (Habe, 1953) (KimMoll466, WAM S90485), new Australian record. Scale bars $500 \mu \mathrm{m}$. 


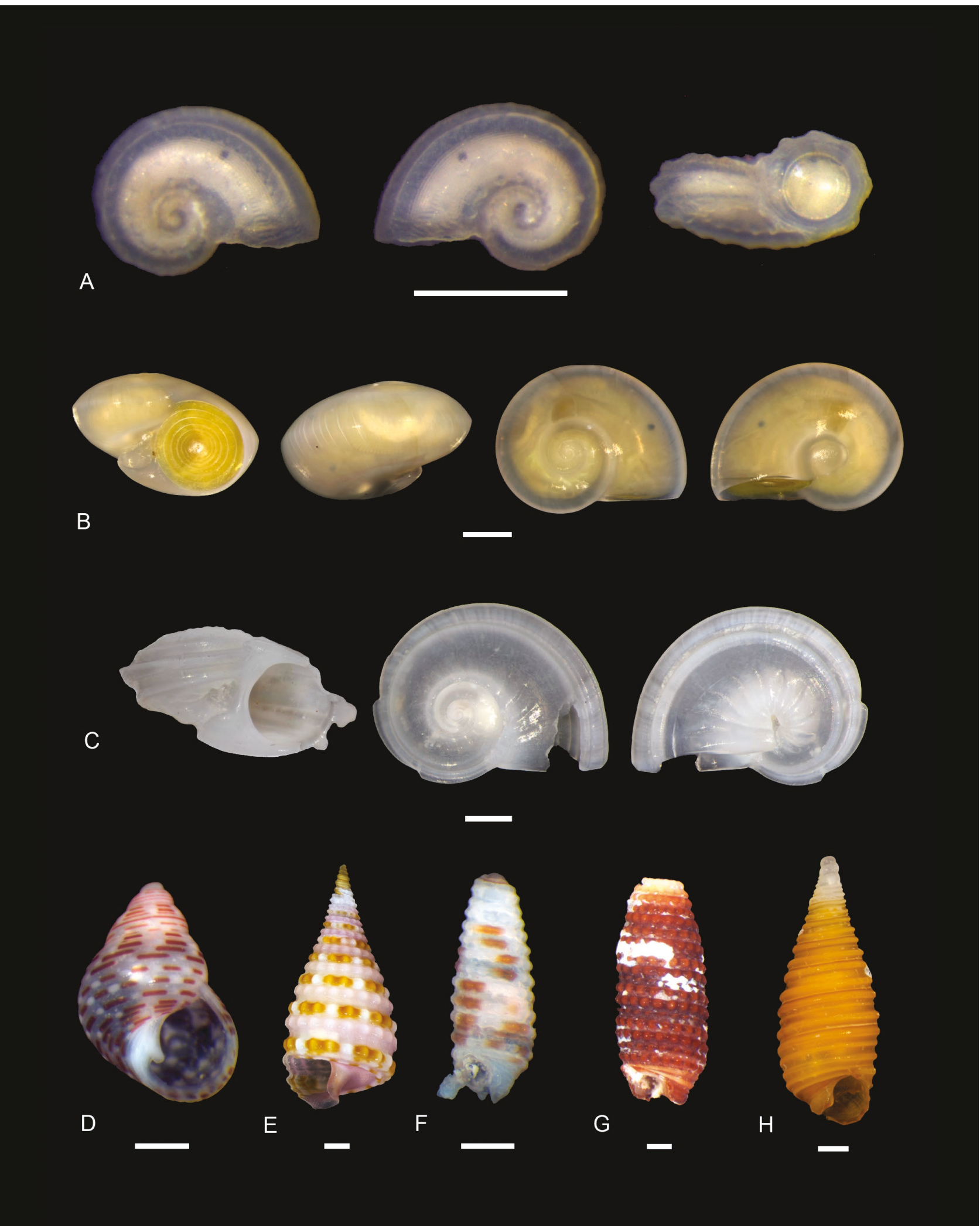

FIGURE 7 New species and records. A) Lodderena ornata (Olsson and McGinty 1958) (KimMoll243, WAM S84767), new Australian record; B) Leucorhynchia caledonica Crosse, 1867 (KimMoll567, WAM S94284), new WA record; C) Leucorhynchia tricarinata Melvill and Standen, 1896) (KimMoll579, WAM S94333), new WA record; D) Alcyna ocellata Adams, 1860 (KimMoll370, WAM S90121), new Australian record; E) Mastonia cf. lamberti (Hervier, 1898) (KimMoll581, WAM S94346) new record for Australia if verified; F) Monophorus cf. tessellatus (Kosuge, 1963) (KimMoll341, WAM S84984), new record for Australia if verified; G) Monophorus cf. atratus (Kosuge, 1962) (KimMoll388, WAM S90168) new record for Australia if verified; H) Paraseila sp. (KimMoll572, WAM S94307), first record of Paraseila in WA. Scale bars 500 $\mu \mathrm{m}$. 


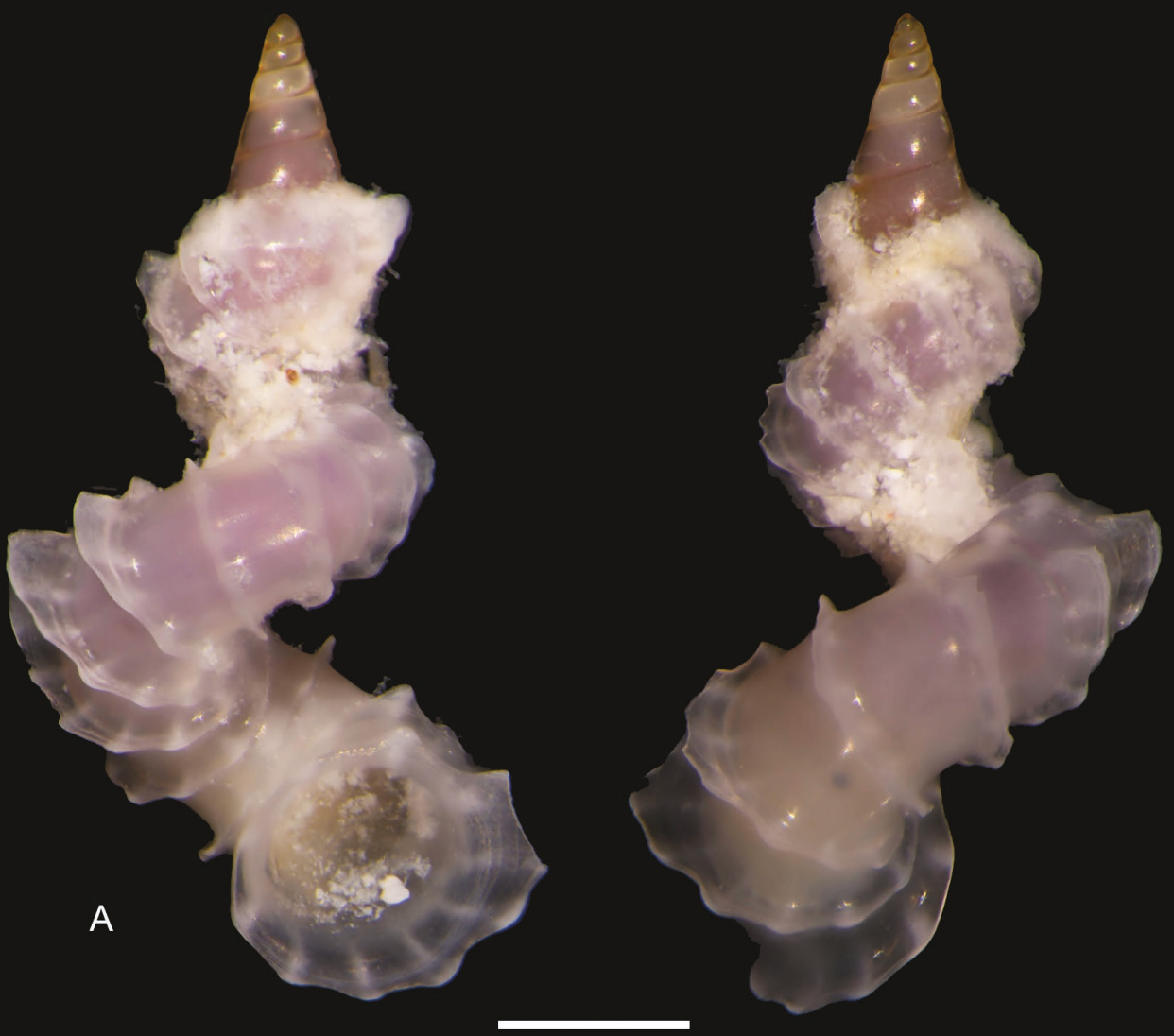

B

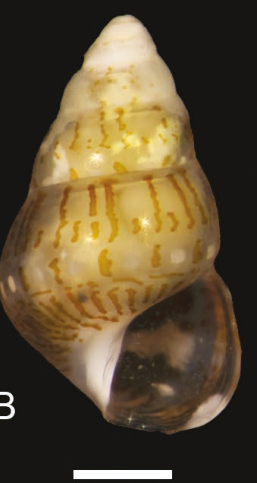

E

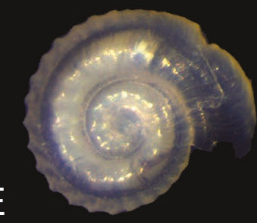

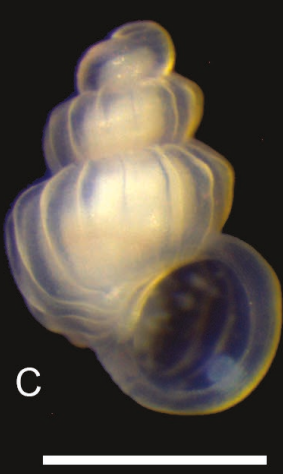
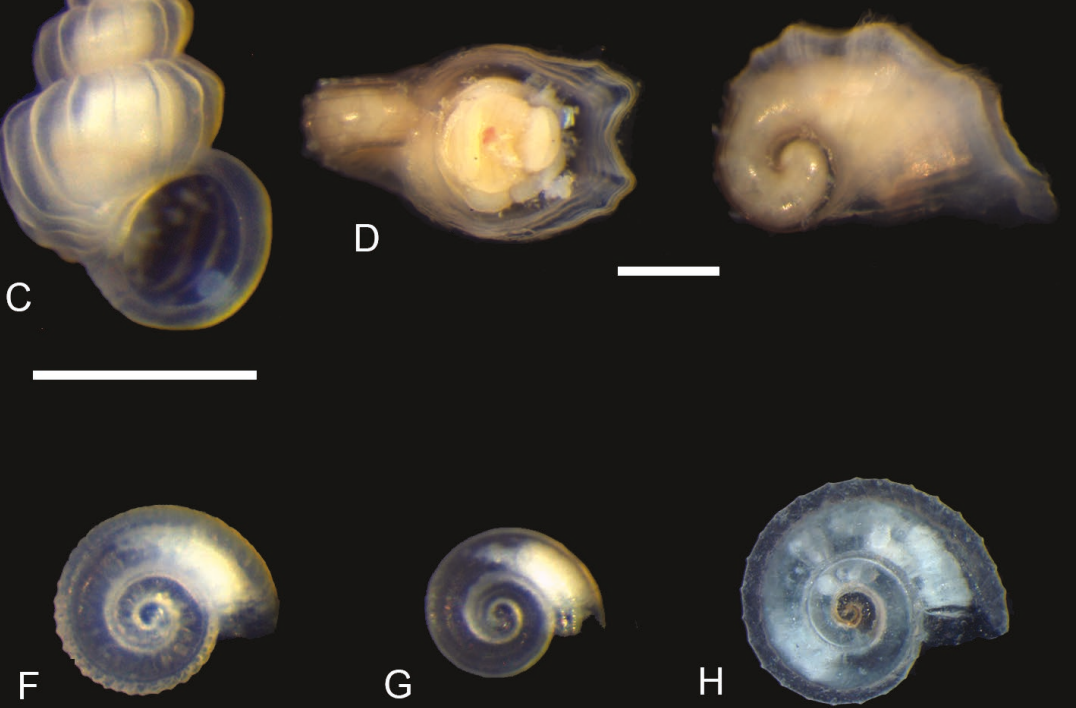

G

$\mathrm{H}$

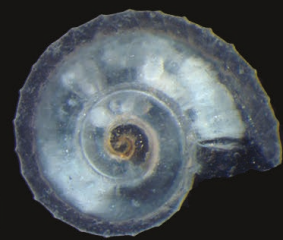

(1) 


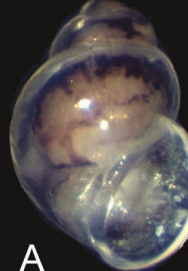

A
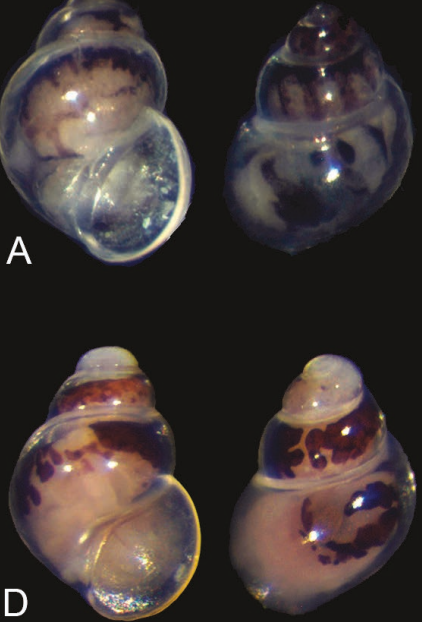

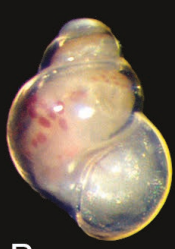

B
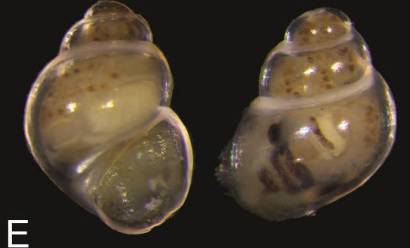

C
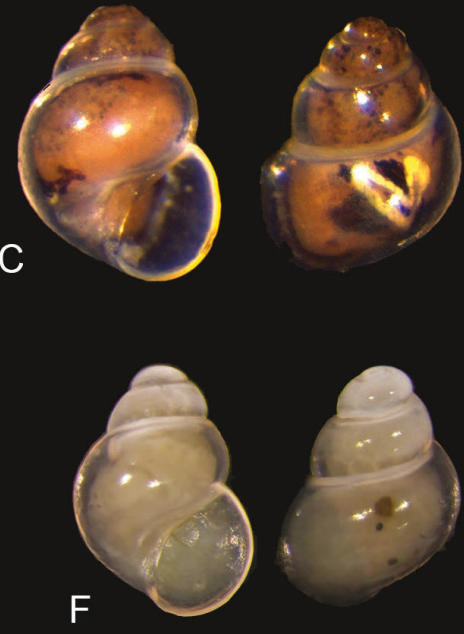

$\mathrm{J}$

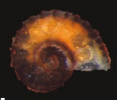

$\mathrm{H}$

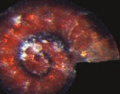

I

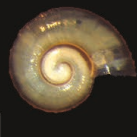

K
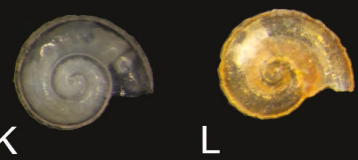

L
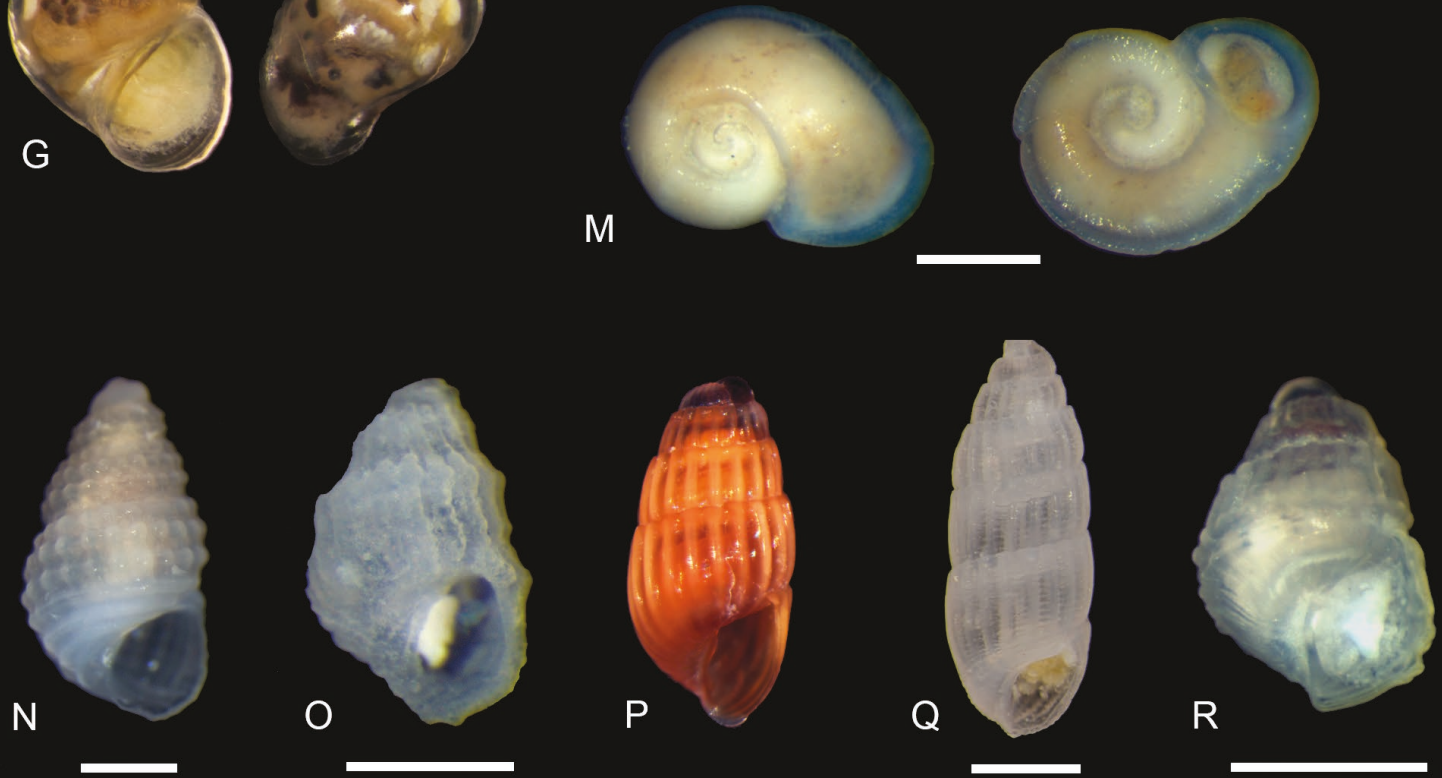

FIGURE 9

New species and records. A) Rissoella sp. (confusa group) (KimMoll10, WAM S84508); B) Rissoella sp. (KimMoll318, WAM S84909); C) Rissoella sp. (KimMoll344, WAM S84988); D) Rissoella sp. (KimMoll352, WAM S90026); E) Rissoella sp. (KimMoll492, S68833); F) Rissoella sp. (KimMoll493, WAM S68834). G) Rissoella sp. (KimMoll535, WAM S94042); H) Ammonicera sp. (KimMoll43, WAM S90437); I) Ammonicera sp. (KimMoll425, WAM S90291); J) Ammonicera sp. (KimMoll431, WAM S90311); K) Ammonicera sp. (KimMoll489, WAM S94449); L) Ammonicera sp. (KimMoll598, WAM S94480); M) Moerchia cf. introspecta Hedley, 1907 (KimMoll201, WAM S84712); N) Chrysallida zea (Hedley, 1902) (KimMoll13, S84527); O) Herewardia kesteveni (Hedley, 1907) (KimMoll408, WAM S90231); P) Odostomella opaca (Hedley, 1906) (KimMoll428, WAM S90303), not to scale; Q) Turbonilla microscopica Laseron, 1959 (KimMoll561, WAM S94233); R) Besla articulata (Hedley, 1909) (KimMoll59, WAM S84562). A-L new species, $M-R$ new records for WA. Scale 500 $\mu m$, A-L share the same scale. 


\section{Superfamily Limoidea}

\section{Family Limidae}

\section{Class Bivalvia}

\section{Subclass Protobranchia}

\section{Superfamily Nuculoidea}

\section{Family Nuculidae}

The Nuculidae include the world's smallest mollusc measuring only $400 \mu \mathrm{m}$ (Anders Warén personal communication); see Bergmans (1978) and Huber (2010) for recent overviews. Four species were found in this study. This low diversity is likely due to the focus on hard bottom reef areas during the Kimberley survey.

\section{Subclass Pteriomorphia Superfamily Arcoidea \\ Family Arcidae}

Twelve species were found. While some of the species recorded were juvenile arks, this reduced number of species illustrates the bias towards sampling of larger species during earlier surveys and their partial affiliation with softer sediments (e.g. Anadara lives in soft sediments, as opposed to Barbatia which is found attached with a byssus to hard substrates).

\section{Family Philobryidae}

The philobryids are a diverse assemblage of very small filter feeding pteriomorphs, taxonomically covered in Laseron (1953) and Tevesz (1977). These very small mussel-shaped bivalves cling to hard substrates with a byssus and are particularly abundant in caves. They have a characteristic embryonic shell resembling a small hat and are direct developers. Seven morphospecies were found in this study, most from offshore stations. No member of this family was reported in the Kimberley historic mollusc paper (Willan et al. 2015) and there are no records from northern WA (ALA, AFD).

\section{Superfamily Mytiloidea Family Mytilidae}

Most of the mytilids recorded were juvenile or small specimens from a common macro species, including Septifer cumingii Récluz, 1849 (KimMoll52, WAM S68867).
Micro-limids represented about half of the diversity compared to the Kimberley historic mollusc paper (five in this study versus nine in Willan et al. 2015).

\section{Superfamily Pterioidea}

\section{Families Pteriidae and Malleidae}

The sampled pteriids and malleids were mainly juveniles or spat and sorting was halted due to the difficulty of separating dead from live material at the species level and linking dead shells to live collected material for these families.

\section{Superfamily Pectinoidea \\ Family Propeamussidae}

The propeamussiids consisted of three morphospecies. The material of two of them consisted of left valves only, while the third species was represented by a single right valve. It is possible that these three morphospecies represent growth stages of a single inequivalve species (see Cyclopecten ryukyuensis (Hyamy and Kase, 1991 in Okutani 2000: 915, pl. 455, fig. 16), but unless a full specimen with right and left valves intact is found, the link between the valves cannot be made with certainty. These records are significant as their small size rules out any affinity with Amusium spp., the only closely related taxon reported in the Kimberley historic mollusc paper (Willan et al. 2015).

\section{Family Spondylidae}

Only two juvenile spondyliids were found. In contrast, Willan et al. (2015) recorded 13 species of Spondylus.

\section{Subclass Heterodonta}

\section{Superfamily Carditoidea}

\section{Family Carditidae}

The carditiids include some truly microscopic species (Table 2), one of which, Cyclocardia sp.: KimMoll560, WAM S94232, was found only at Rowley Shoals stations (see Bryce et al. 2018). 


\section{Family Condylocardiidae}

The condylocardiids were represented by the two subfamilies, Condylocardiinae and Cuninae, both reviewed by Laseron (1953) and Middelfart $(2002 a, b)$. A total of 15 species were found in this study, with seven of the most common observed at Station 91/K12. At least three new species (KimMoll230, KimMoll457 and KimMoll501) and possibly two new genera (KimMoll457 and KimMoll502) await formal description. Only species KimMoll230 and KimMoll76 were found more than once, illustrating the rarity of this group. Only two specimens of two species were taken alive, Warrana brucemarshalli Middelfart, 2002 (KimMoll76) and ?Crassacuna (KimMoll582).

\section{Family Crassatellidae}

Three crassatellid species were found at offshore stations (134/K13, 153/K14, and 175/K14) (Table 2) and none overlapped at the species level with those recorded in the Kimberley historic mollusc paper (Willan et al. 2015).

\section{Superfamilies Hiatellolidea, Tellinoidea, Lucinoidea, Arcticoidea and Veneroidea}

While the micro-hiatellids were equal in species numbers to those reported in the Kimberley historic mollusc paper (Willan et al. 2015), the semelids, tellinids, lucinids, trapezids and venerids were far more prevalent in the Kimberley historic mollusc paper (Willan et al. 2015), because of their typically large adult size making them conspicuous in the field.

\section{Superfamily Chamoidea \\ Family Chamidae}

The micro-chamiids were all juvenile. In contrast, the Kimberley historic mollusc paper by Willan et al. (2015) recorded five species of Chama.

\section{Superfamily Galeommatoidea}

The galeommatoideans are a challenging superfamily with either a complete lack of characters or a myriad of unique ones (Goto et al. 2012), making resolution of relationships difficult. The superfamily was represented by 20 species in this study, mainly montacutids (e.g. Mysella spp.). This material represents two new species (KimMoll517 and KimMoll483) and KimMoll517 is also a new genus. While there is a recent overview
(Huber 2015), the superfamily is under revision. There are currently 14 families (Middelfart in prep.), hence molecular systematics are needed to clarify relationships (Goto et al. 2012; Li et al. 2012).

\section{Superfamilies Ungulinoidea, Gastrochaenoidea, Mactroidea and Myoidea}

The micro-gastrochaenids were represented only from inshore stations (110/K12 and 116/K12) by live material, while micro-representatives of mesodesmatids, corbulids, myids, pholadids and ungulinids were all dead collected in low numbers and some are most likely juvenile.

\section{Superfamily Veneroidea}

\section{Family Neoleptonidae}

The neoleptonids are under revision (Middelfart in prep.), but include three genera, Neolepton, Micropolia and Puysegeria (the latter ?Neoleptonidae Middelfart 2002: 79). KimMoll83 might be a juvenile venerid and KimMoll250 could be affiliated with cyamiids, but with a transposed hinge. Hinge transposition is known from lower heterodonts (Cox et al. 1969).

\section{Class Scaphopoda}

Lamprell and Healy (1998) revised the Australian scaphopods. Two species were encountered; Gadila brycei Lamprell and Healy, 1998 (KimMoll84, WAM S84587) and a juvenile Fissidentalium sp. (KimMoll84, WAM S84587), both from Station 91/K12.

\section{Class Polyplacophora}

Minute polyplacophorans were found predominantly from offshore stations 109/K12, 127/ K13, 136/K13 and 137/K13 (Table 2). All belong in the Leptochitonidae.

\section{Class Gastropoda}

Many representatives of this class were obtained during this project. Table 2 provides records of Hipponicidae, Vermetidae, Triviidae, Velutinidae, Atlantidae, Ranellidae, Colubrariidae, Columbellidae, Drillidae, Conidae, Murchisonellidae, Aplustridae, Cylichnidae, Pleurobranchidae, Ringiculidae, Aplysiidae, Philinidae, Cavoliniidae, and Discodorididae. 


\section{Subclass Patellogastropoda}

Only one patellogastropod limpet species was found, and it was only collected from offshore stations 134/K13, 139/K13, 143/K13 and 169/K14 (Table 2).

\section{Subclass Vetigastropoda}

\section{Superfamily Scissurelloidea}

\section{Family Scissurellidae}

Although diverse in the $0-30 \mathrm{~m}$ depth range (Geiger 2012, Figure 26), only five species were identified in the study. This represents less than $10 \%$ of the Indo-Malayan Archipelago's diversity (sensu Geiger 2012). The most common species was Scissurella sp. (KimMoll4) identified from 25 stations, while the less common Sukashitrochus atkinsoni (Tenison-Woods, 1877) (KimMoll404) was identified from five stations. The least common species, Scissurella sp. (KimMoll577) was only identified from one station (Station 156/K14).

\section{Superfamily Fissurelloidea}

\section{Family Fissurellidae}

The fissurellids were mostly juveniles or broken shells of larger species, with KimMoll299 (Puncturella sp.) being the only true microfissurellid discovered during the study.

\section{Superfamily Haliotoidea}

KimMoll460 (Ma category) was the only species of haliotid, represented by juvenile shells from stations 139/K13 and 150/K14.

\section{Superfamily Trochoidea and family Turbinidae}

The only calliostomatids recovered were from Station 91/K12 (Table 2). The six species of liotiids recorded were Austroliotia sp. and Bathyliotina schepmani (Habe, 1953) from Station 145/K13, with the latter a new record for Australia. The phasianellid genus Tricolia was represented by five species and Gabrielona was represented by two species. Gabrielona sp. (KimMoll494, S68836) might be conspecific with Gabrielona pisinna Robertson, 1973 once more material is examined.

Thirteen species of skeneids were found, with the planispiral species Lodderena ornata (Olsson and McGinty, 1958) recorded for the first time from the central Indo-west Pacific. Previously considered an Atlantic species; however, some Red Sea and Pacific records do exist (Lima et al. 2011), and more research is needed to clarify conspecificity. This species formed part of the numerous, possibly congeneric, series that also includes the less planispiral Lodderena sp. (KimMoll237, WAM S84760). Two Leucorhynchia spp. (Leucorhynchia caledonica Crosse, 1867 and Leucorhynchia tricarinata Melvill and Standen, 1896) were recovered from the southern offshore stations (154, 156, 161 and 165/K14), and both are new records for WA (ALA). The trochids and turbinids form complicated assemblages, which are challenging to place as either juvenile macro or true micromolluscs. However, Alcyna ocellata A. Adams, 1860 is significant and is recorded for the first time from Australia (ALA, AFD).

\section{Superfamily Sequenzoidea}

A minute and characteristic seguenzioidean species of the genus Brookula (KimMoll415, WAM S90258) was found exclusively offshore. The superfamily was not recorded in the Kimberley historic mollusc paper (Willan et al. 2015) as the paper only included molluscan holdings housed in the WAM and Museum and Art Gallery of the Northern Territory from the Project Area; however, specimens from the Kimberley do exist in other institutions.

\section{Subclass Caenogastropoda}

\section{Superfamily Cerithioidea}

Cerithidium perparvulum (Watson, 1886) was one of the most common micromolluscs in the study. The dialids were represented by five species, with Diala albugo (Watson, 1886) the most common. The litiopids belong in the Cerithioidea. Houbrick (1987) reviewed the anatomical differentiation between genera. There is no extensive review of Australian taxa.

Despite the shallow water focus of this study, all of the live collected Styliferina cf. goniochila A. Adams, 1860 and S. cf. translucida (Hedley, 1906) were found in depths of $10 \mathrm{~m}$ or more at offshore stations, where deeper light penetration might have facilitated growth of algae and seagrass.

Members of the Pickworthiidae are close relatives of the familiar periwinkles often seen on rocky shores and in mangrove trees, but are very small and live hidden in rubble, cracks and crevices or caves in deeper water. Nothing is known about the biology of these snails. The pickworthiids were generally found offshore and while the IndoPacific Astrosansonia dautzenbergi (Bavay, 1917) is noteworthy, Sansonia sp. (KimMoll452) was the most prevalent in offshore material. None of the scaliolids (Scaliola spp.) were encountered alive, 
only the larger and more common Finella sp., a genus also recorded in the Kimberley historic mollusc paper (Willan et al. 2015), was found in the micromollusc samples.

\section{Superfamily Triphoroidea}

Members of the Cerithiopsidae are very close relatives of the triphorids. Of the 16 species of cerithiopsids, none were found inshore with live material only found from offshore stations. However, new data have revealed this group does occur in the inshore Kimberley with a single record from Bonaparte Archipelago (Middelfart et al. unpublished). The group is in need of revision, with only Laseron (1956a) and the Philippine work by Cecalupo and Perugia (2012) providing taxonomic works useful for identification purposes. Laseron (1958a) was the last researcher to assess the northern Triphoridae taxonomically. The south Australian triphorid fauna was reviewed by Marshall (1983) and is better known, and deepsea species have been recently studied (Fernandes and Pimenta 2017). Forty triphorid species were recorded in this study compared to 11 in the Kimberley historic mollusc paper (Willan et al. 2015). This is to be expected given that most species are diminutive (Willan et al. 2015).

Costatophora granifera (Brazier, 1894) has several synonyms, two of which are from Thiele's work on Western Australian molluscs (see Thiele, 1930 and Albano and Bakker, 2016) and the rest are from NSW (Laseron, 1954). Based on the material observed, the morphological variation is substantial and might collapse the various morphs of Costatophora found in this study (KimMoll21, KimMoll213, KimMoll217). Iniforis progressa (Laseron, 1958a) was described from Christmas Island, with other records from WA, while Okutani (2017) described a distribution ranging from Japan to northern Australia. The OTU KimMoll581 (WAM S94346) aligns with Mastonia lamberti (Hervier, 1898), which has not previously been recorded from Australia (AFD and ALA). Mastoniaeforis decorata (Laseron, 1958a) is also described from Christmas Island, but aligns with taxon KimMoll570 from Station 154/K14. Metaxia fuscoapicata Thiele, 1930 is recorded from north of Exmouth and off Lake Macleod, WA. The range is thus extended northeast to the Kimberley survey area. The taxa KimMoll373 and KimMoll341 align with Monophorus tessellatus (Kosuge, 1963), which has not previously been recorded from Australia and are most likely that species, which follows Okutani $(2000,2017)$. The same can be said for
KimMoll388, which aligns with Monophorus cf. atratus (Kosuge, 1962). Monophorus episcopalis (Hervier, 1898) is recorded from northern Australia (Chang and Wu 2005 through AFD) and ALA has records from New Caledonia, therefore KimMoll463 is tentatively attributed to this taxon, forming a starting point for exploring this species through vouchered Australian material. The taxon identified as Opimaphora cf. sarcira Laseron, 1958a, while resembling that species in coloration and shape, differs in having weaker, less nodulose spirals and a protoconch with two spiral ridges and axial ribs. Subulophora rutilans (Hervier, 1897) is most likely a widely distributed Indo-Pacific species (ALA, AFD, Marshall 1983) and aligns well with KimMoll24. Viriola cancellata (Hinds, 1843) has an Indo-Pacific wide distribution and is known from the Queensland coast, Cocos (Keeling) Islands (AFD) and Ashmore Reef (ALA, Museum and Art Gallery of the Northern Territory records) and is reported from stations 109/K12, 154/K14 and 174/K14.

\section{Superfamily Epitonoidea}

Epitoniids or wentletraps are circumglobal, but particularly diverse in the central Indo-west Pacific (Weil et al. 1999). This study found two morphospecies in Cycloscala Dall, 1889, including the live collected Cycloscala revoluta (KimMoll350). Both species were found at inshore stations 91/ K12 and 93/K12 and at offshore stations 128/K13 and $130 / K 13$. The entire group are specialised cnidarian predators, many on the shade-loving hard coral, Tubastrea. Cycloscala revoluta (Fig. 8A) was found living in less than $20 \mathrm{~m}$ in a habitat with caves, vertical coral walls and cnidarians, and was the only live epitoniid micromollusc found during the entire study. Garcia (2004) reviewed the genus Cycloscala. Eleven additional epitoniid species were collected from Station 91/K12.

\section{Superfamily Campaniloidea}

The family Plesiotrochidae was mainly represented by Plesiotrochus unicinctus (A. Adams, 1853) from offshore sites, which matches previous records from the same area (ALA). Another possible aberrant form was found, but may be a worn specimen (KimMoll503).

\section{Superfamily Rissoidea}

Generic identification of Rissoidae/Rissoinidae was facilitated by Ponder (1985) and the family has been addressed (Criscione and Ponder 2013), with 
the rissoids recovered as polyphyletic. The genus Rissoina was given familial status by Criscione and Ponder (2013) based on molecular research. Apataxia cerithiiformis (Tryon, 1887) was quite common offshore and has been recorded previously from the Kimberley (ALA). Although Haurakia marmorata (Hedley, 1907) was very common at southern offshore stations, no record was found in the historical records (ALA) from WA or NT. The congener H. novarensis (Frauenfeld, 1867) was only found from northern offshore stations, but appears to be present from the inshore Pilbara (ALA and P. Middelfart, personal observation). Parashiela cf. invisibilis (Hedley, 1899) was one of the most common molluscs, but only found alive offshore. The congener P. liddelliana (Hedley, 1907) was also recorded offshore, but at fewer stations, and is a new record for WA. Three additional species (KimMoll508, KimMoll305 and KimMoll514) also align with the genus Parasheila. Another common species, the zebinid, Pandalosia ephamilla (Watson, 1886), has a unique morphology resembling some eulimids and has an Indo-Pacific distribution, known from eastern Australia and the Sahul Bank, Timor Sea (Australian Museum via OZCAM). Rissoina ambigua (Gould, 1849) was found alive offshore and is the first record of this species in the Kimberley (compare ALA).

\section{Superfamily Capuloidea}

Only one capulid was found live, Trichamathina sp., a genus not previously recorded from Australia (AFD, ALA).

\section{Superfamily Cingulopsoidea}

Ponder and Yoo (1978) revised the Australian Eatoniellidae. Names have not been allocated to the eatoniellids from the study, despite one species being exceedingly common offshore.

\section{Superfamily Truncatelloidea}

The anabathrids were uncommon with only six species found and only one of them was live (Anabathron sp., KimMoll247). The Caecidae is a common component of the Kimberley smallermollusc assemblage and has been revised (Pizzini 2013). Eighteen species were found in this study. The most common species, Caecum sepimentum de Folin, 1868 , was mostly found offshore, with one lot identified from a mid-shelf station (148/K13). Two uncommon, dead-collected Iravadiids were included in the sorted samples.
Layton et al. (2019) transferred Spirostyliferina lizardensis Bandel, 2006 from the Litiopidae to the new genus Spirostyliferinidae.

The tornids are represented by 16 species with most records from offshore sites. Lophocochlias sp. was the most prevalent species encountered. The systematic position of Lophocochlias has been clarified for representatives from this study.

\section{Family Tornidae}

\section{Genus Lophocochlias Pilsbry, 1921}

Haplocochlias (Lophocochlias) Pilsbry, 1921: 377. Type species Haplocochlias (Lophocochlias) minutissimus Pilsbry, 1921: 377 (monotypy), syn. of Lophocochlias parvissimus (Hedley, 1899).

Aqabarella Alhejoj, Bandel and Al-Najjar, 2016:418. Type species: Aqabarella urdunensis Alhejoj, Bandel and Al-Najjar, 2016 (original designation), unavailable name under ICZN Art. 16.4: no explicit fixation of name-bearing types (placed in Aqabarellidae).

\section{REMARKS}

This genus contains only two living species worldwide (AFD). Familial placement is uncertain as data are absent regarding soft anatomy and molecular systematics.

\section{Lophocochlias parvissimus (Hedley, 1899)}

Liotia parvissima Hedley, 1899: 554-555. Figure 67. Type locality: Funafuti Atoll.

Haplocochlias (Lophocochlias) minutissimus Pilsbry, 1921:377. Type locality: Hawaii (new synonym).

\section{REMARKS}

Lophocochlias parvissimus was described from Funafuti Atoll in the Pacific Ocean (Hedley, 1899). Despite a review of the genus and the description of a new species, aligning this taxon with the type of Lophocochlias (Lophocochlias) minutissimus (Pilsbry, 1921) has not occurred. After comparing clear images of the type material of L. minutissimus (ANSP) with L. parvissimus (AMS), no discernible differences could be found and they have been synonymised here, a situation suspected by Rubio and Rolán (2015). The species has been recorded from the western and central Pacific Ocean, as well as Cocos (Keeling) Islands and Christmas Island in the Indian Ocean. 


\section{Lophocochlias procerus Rubio and Rolán, 2015}

Lophocochlias procerus Rubio and Rolán, 2015: 113. Figures 5A-G, 6A-G, 7A-E. Holotype IM-200028215. Type locality: Gulf of Aqaba.

Aqabarella urdunensis Alhejoj, Bandel and Al-Najjar, 2016: 418. Plate 6, Figure 6 and Plate 7, Figures 1-6. Type locality: Gulf of Aqaba. Unavailable name under ICZN Art. 16.4: no explicit fixation of name-bearing types.

\section{REMARKS}

Aqabarella pulchella Alhejoj, Bandel and Al-Najjar, 2016 (unaccepted name under IZCN) was placed in the new family Aquabarellidae Alhejoj, Bandel and Al-Najjar, 2016 (unaccepted name under IZCN). In this paper, the authors suggested a close relationship to Pickworthiidae. The placement in Aquabarellidae was discovered by chance, when the first author was conducting literature review for Kimberley Pickworthiidae. The same taxon was earlier described by Rubio and Rolán (2015) as Lophocochlias proceus and placed in the Tornidae. The name and taxonomic placement follows Rubio and Rolán (2015) in this study.

\section{Superfamily Eulimoidea}

Approximately 36 species are known from WA (AFD). Some taxonomic papers for the groups include those by Warén (1980a, b, 1981, 1983, 1984). A total of 22 species of eulimids were collected, 10 of which were found alive. The most common eulimid was Pyramidelloides mirandus (A. Adams, 1861), with its presence in WA consistent with the known distribution (Warén 1983). This species was taken live offshore, but dead at inshore Station 91/K12.

\section{Superfamily Vanikoroidea}

Two species of Macromphalus were recorded from the survey area, M. aspersus (Hedley, 1912) and M. aculeatus (Hedley, 1900), but neither match Macromphalus sp. (KimMoll205, WAM S84717) found in this study. More work is required to revise the 20 or so living species recorded worldwide (P. Middelfart, pers. obs.).

\section{Superfamily Naticoidea}

Naticids are sand/mud dwellers and are underrepresented in this study because of the hard bottom bias of the stations sampled. Two damaged specimens of separate species (KimMoll190, KimMoll193) were sorted from Station 91/K12.

\section{Superfamily Buccinoidea}

Although the Australian fauna is substantial, in excess of 78 species (AFD), only one species (KimMoll334), represented by a single specimen was recorded from each of the stations 114/K12 and 152/K14. This is most likely due to sampling bias towards hard substrates and macromolluscs. KimMoll334 aligns with Reticunassa cockburnensis (Kool and Dekker, 2006), but the distribution is apparently disjunct. This species was originally described from Cockburn Sound near Perth, southern WA, with a southerly distribution to Esperance. It is absent from the mid-coast of WA, and recorded again in the north, from Exmouth northward to the offshore atolls of the Kimberley.

\section{Superfamily Conoidea}

The polyphyletic 'turrids' have been revised and the family has now been split into 13 monophyletic families (Bouchet et al. 2011). This has a major impact on the classification of taxa and crossreferencing previous checklists assembled from not only WA but Australia as a whole. However, taxa may still be tracked at the genus level or below. Relevant families for this study include Clathurellidae, Horaiclavidae, Mageliidae and Raphitomidae. The clathurellids are a small-sized group of non-operculate conoideans. Lienardia rubida (Hinds, 1843) (KimMoll571, WAM S94306) has been recorded from Ashmore Reef (ALA) and was recorded live in this study from Mermaid Reef, Rowley Shoals (Station 156/K14). The most common clathurellid was ?Lienardia sp. (KimMoll402, WAM S94322) from Heywood Shoal (Station 148/ K14), a mid-shelf rise between Hibernia Reef and Rowley Shoals. Two additional species (KimMoll90, KimMol193) were identified from the inshore Station 91/K12.

The Horaiclavidae (Bouchet et al. 2011) is an assemblage of genera that exhibit varying morphological traits, but are united by molecular data (Bouchet et al. 2011, p. 293, 296). A key is lacking, and identification relies on a few characters, including a stout shell, short siphonal canal and weak spiral sculpture. The most commonly encountered 'turrid' was Carinapex minutissima (Garrett, 1875) (KimMoll293) identified from 11 offshore stations. This occurrence is consistent with the distributional data in ALA, which indicates a 'clear water' distribution off NSW, Qld and WA (Ashmore and northern Ningaloo Reef). Carinapex sp. (KimMoll574) is similar to Ceritoturris theoteles (Melvill and Standen, 1896) (= Iredalea theoteles (Melvill and Standen, 1896). It is hard to discern from the illustration by Melvill and Standen (1897), but Iredalea s.s. appears to be different to KimMoll574 (compare Oliver 1915: 538. 
Plate 11, Figure 34). Morphologically KimMoll574 appears similar to C. minutissima with a deep anal sulcus, teleoconch nodules and a monocarinate protoconch. More information on I. theoteles and justification of its placement in Iredalea (placed in the Drillidae) may change that. One single dead specimen of KimMoll464 from Ashmore Reef has not been placed, but aligns with the horaiclavids.

The re-ranked mangellids are generally medium to small shouldered 'turrids' with strong axials. The protoconch is very characteristic with a sinusigera varix. Four species have been identified; two (KimMoll409, KimMoll519) from Ashmore Reef and two (KimMoll89, KimMoll91) from Station 91/K12.

The family Raphitomidae is highly variable and hard to determine morphologically. All the species identified in this group were infrequently encountered with only Microdaphne morrisoni Rehder, 1981 (KimMoll575) recorded at two stations from Clerke and Imperieuse Reefs (Station 156/K14 and 165/K14 respectively). Exomiles sp. (KimMoll467) is another oceanic species, only found south of Hibernia Reef (Station 145/K13). Veprecula spp. (KimMoll86, KimMoll87) were only discovered as singletons at Station 91/K12.

\section{Unassigned superfamily (WoRMS) (previously Volutoidea)}

While the supraspecific classification of marginellids is now clearer (G.A. and H.R. Coovert 1995), the Australian marginellid and cysticid fauna is in need of major revision. The most recent work at the species level in Australia was by Laseron (1957). Many of the described Australian species have been illustrated by Beechey (http://seashellsofnsw.org.au) and subsequently by Cossignani (2006). A very helpful key to genera is provided by G.A. and H.R. Coovert (1995). The most common species was KimMoll371, which was only found from Ashmore Reef. KimMoll41 aligns with Pugnus Hedley, 1896 (type Pugnus parvus Heldey, 1896). Only one species of Pugnus (the type) has been recorded in Australia (ALA), and its distribution does not include tropical Australia, so more work is required. There are five additional species worldwide (WoRMS), with only Pugnus maesae Roth, 1972 from the Indo-Pacific Ocean. KimMoll41 cannot currently be assigned to any species.

\section{Superfamily Mitroidea}

The mitrid family is mainly macroscopic and only two species, both represented by single specimens, were identified from Heywood Shoal (Station 109/K12). It is possible both species are juvenile Scabricola.

\section{Superfamily Muricoidea}

The group is mainly macroscopic, but a few species meet the Me category, e.g. Aspella. In this study mostly young post-metamorphic juveniles were found and they proved almost impossible to place, although KimMoll285 is likely to be a muricine. A juvenile specimen of Magilus striatus (Rüppell, 1835) (sensu Okutani 2000) (= Leptoconchus peronii (Lamarck, 1818), a coral-inhabiting species, was found from Imperieuse Reef (Station 165/K14).

\section{Subclass Heterobranchia}

\section{Superfamily Orbitestelloidea}

Orbitestellidae in Australia and the Australian territories consists of just over 10 species (Laseron 1954, 1958, Marshall 1988, Ponder 1990, Beesley et al. 1998). Only two species of Orbitestella and two of Microdiscula have been described from tropical Australia and neither was recorded from tropical WA until now. All four species recovered during this study are new. KimMoll240 was the most common species in twelve stations, while KimMoll360 was found in eight stations.

\section{Superfamily Omalogyroidea}

The Omalogyridae was taxonomically assessed relatively recently (Sartori and Bieler 2014). There are 33 species worldwide and 11 in Japan, Papua New Guinea and the Maldives. Only two species are known from Australia, both described from NSW (redescribed by Sartori and Bieler 2014). At present no other species is known from Australia despite the existence of numerous species mentioned in Beesley et al. (1998). Four species, all of which are new, and one new record (KimMoll489), have been sorted from this study. Some of the species are quite common with KimMoll43 identified from 16 stations and KimMoll425 from 12 stations. In contrast, only two specimens of KimMoll598 were found from Imperieuse Reef (Station 165/K14).

\section{Superfamily Rissoelloidea}

The Rissoellidae was last assessed by Ponder and Yoo (1977) and reviewed in Beesley et al. (1998). There are 54 species known worldwide (Caballer et al. 2011, 2014) and 14 species from Australia (Ponder and Yoo 1977). However, no species have been reported from Exmouth, WA, to Torres Strait, Qld. Since Ponder and Yoo (1977), no additional species have been added to the Australian fauna. WAM collections from this study indicate there are at least seven putative new species. 


\section{Superfamily Haminoeoidea}

Six species were identified, of which three were live collected from offshore stations (e.g. Station 111/K12, see Table 2).

\section{Superfamily Pyramidelloidea}

Moerchia introspecta (Hedley, 1907), described from Masthead Reef, Qld, and subsequently discovered in Darwin (listed in Laseron (1958), is recorded for the first time in WA (ALA). Other new WA records are: Odostomella opaca (Hedley, 1906), previously known only from eastern Australia; Turbonilla microscopica Laseron, 1959, originally described from Darwin; Besla articulata (Hedley, 1909) originally recorded from Hope Island, Qld; Chrysallida zea (Hedley, 1902) originally recorded from northern Qld; Chrysallida kesteveni (Hedley, 1907) with its type locality at Masthead Reef, Qld, was moved to the genus Herewardia Iredale, 1935 by Peñas and Rolán (2017) (Rissoidae), but transferred to Chrysallida (see WoRMS).

\section{Superfamily Oxynooidea}

Three species, belonging in Berthelinia and Julia were found in this study. Two species of Berthelinia have been described from Australia (Jensen 1993, 1997), but cannot be identified on their shells alone and require dissection for verification (Kathe Jensen, personal communication).

\section{DISCUSSION}

This study of smaller molluscs has added significantly to the knowledge of molluscan biodiversity and biogeography in the Kimberley Project Area. It has documented 624 species across 102 families or superfamilies, which includes 26 new species and 23 new records for WA and Australia.

Twenty one families were added to the Kimberley historical mollusc inventory published by Willan et al. (2015) (Figure 2), and more families could be added with more collecting and research.

The samples included in this survey yielded 1,883 identified lots representing 505 molluscan morphospecies from $\leq 5 \mathrm{~mm}$ adult size category (M), 43 molluscs from $>5-10 \mathrm{~mm}$ adult size category (Me), 68 macromolluscs from the $>10 \mathrm{~mm}$ adult size category $(\mathbf{M a})$, and 8 species whose adult size could not be determined.

The level of micromollusc diversity in the $\leq 5 \mathrm{~mm}$ adult size class category for Hawai'i is more than the 317-375 species (Campagnari and Geiger
2018), but less than the 864 species (under $4.1 \mathrm{~mm}$ ) collected at Koumac, New Caledonia (Bouchet et al. 2002). The latter study encompassed the highest habitat diversity while this present study covered the largest geographic area of 476,000 $\mathrm{km}^{2}$ (Bryce et al. 2018) versus $295 \mathrm{~km}^{2}$ at Koumac and $18 \mathrm{~km}^{2}$ on Hawai'i. The diversity of smaller molluscs in the Kimberley survey area, including a significant component $(81 \%)$ of micromolluscs $(\leq 5$ $\mathrm{mm}$ adult size class), is yet to reach an asymptote (Figure 1). More species will be encountered once additional habitat types are surveyed, including soft benthic substrates, seagrass beds, deeper waters, mangroves and host-specific taxa living with or on other marine invertebrates.

This study has indicated how much diversity has been missed by earlier expeditions, which did not target smaller molluscs specifically (Willan 2005; Willan et al. 2015). This study highlights the additional diversity afforded when a smaller mollusc component is added. Ignoring them leads to an underestimate and incomplete assessment of molluscan diversity in broader biodiversity contexts.

\section{ACKNOWLEDGEMENTS}

The WAM respectfully acknowledge the Traditional Custodians of the Kimberley land and sea country, of Elders past and present, and in particular the Dambimangari and Wunambal Gaambera peoples, for collections made on their sea country.

We appreciate comments by Winston Ponder, Daniel Geiger, Richard Willan and Kathe Jensen. We are grateful for the suggestions made by two reviewers, both of whom greatly improved this manuscript and the editor. We acknowledge Alison Miller and Mandy Reid for information on Lophocochlias spp. and are grateful to Corey Whisson for databasing this material. Sincere thanks to Woodside for long standing support in association with the Western Australian Museum during the Woodside Collection Project (Kimberley).

\section{REFERENCES}

AFD (Australian Faunal Directory) (2018). Canberra, Australia: http://www.environment.gov.au/ biodiversity/abrs/online-resources/fauna/afd/home

ALA (Atlas of Living Australia) (2018). Canberra, Australia: https://www.ala.org.au/

Albano, P., Sabelli, B. and Bouchet, P. (2011). The challenge of small and rare species in marine biodiversity surveys: microgastropod diversity in a complex tropical coastal environment. Biodiversity and Conservation 20: 3223-3237. 
Albano, P.G. and Bakker, P.A.J. (2016). Annotated catalogue of the types of Triphoridae (Mollusca, Gastropoda) in the Museum für Naturkunde, Berlin, with lectotype designations. Zoosystematics and Evolution 92(1): 33-78.

Barnes, R.S.K. (2019). Spatial structure of a multi-species guild: the dominant biofilm-grazing microgastropods of seagrass. Hydrobiologia 827: 293-307. doi: 10.1007/ s10750-018-3781-y

Beechey, D. (2020). The Seashells of New South Wales. Based on the collections of the Australian Museum and of the author. Release 28. http:/ / seashellsofnsw.org.au.

Beesley, P.L., Ross, G.J.B. and Wells, A. (eds). (1998). Mollusca: The Southern Synthesis. Fauna of Australia. Melbourne: CSIRO Publishing, Volume 5 (Parts A and B).

Bergmans, W. (1978). Taxonomic revision of recent Australian nuculidae (Mollusca: Bivalvia), except Ennucula Iredale, 1931. Records of the Australian Museum 31(17): 673-736.

Bryce, C., Bryce, M. and Radford, B.T. (2018). Kimberley marine biota. Survey data: project methods and station geomorphology. Records of the Western Australian Museum Supplement 85: 1-43. doi: 10.18195/issn.0313-122x.85.2018.001-043

Bouchet, P., Lozouet, P., Maestrati, P. and Heros, V. (2002). Assessing the magnitude of species richness in tropical marine environments: exceptionally high numbers of molluscs at a New Caledonia site. Biological Journal of the Linnean Society 75: 421-436.

Caballer, M., Ortea, J. and Narciso, S. (2011). Description of two new species of Rissoella Gray, 1847 (Mollusca, Gastropoda, Heterobranchia) from Venezuela, with a key to the Caribbean species known for the genus. ZooKeys 115: 1-18. doi: 10.3897/zookeys.115.1163.

Caballer, M., Ortea, J. and Redfern, C. (2014). On the genus Rissoella Gray, 1847 (Gastropoda: Heterobranchia: Rissoellidae) in the Bahamas. American Malacological Bulletin 32(1): 104-121.

Campagnari, B. and Geiger, D. (2018). How many micromollusks are there? A case study on species richness in Hawai'i, with the description of a new species of Murdochella (Gastropoda: Epitoniidae). The Nautilus 132(3-4): 83-90.

Cecalupo A. and Perugia, I. (2012). Family Cerithiopsidae H. Adams and A. Adams, 1853 in the central Philippines (Caenogastropoda: Triphoroidea). Quaderni della Civica Stazione Idrobiologica di Milano 30: $1-262$.

Chang, C-K. and Wu, W-L. (2005). The Taiwan Mollusks II - Triphoridae (Mollusca: Mesogastropoda) from Lutao, Taitung. Taiwan: Research Centre for Biodiversity, Academia Sinica.

Coovert, G.A. and Coovert, H.K. (1995). Revision of the supraspecific classification of marginelliform gastropods. Nautilus 109(2-3): 43-110.

Cossignani, T. (2006). Marginellidae and Cysticidae of the World. Atlas with over 2600 species. L'Informatore Piceno, Ancona.

Cox, L. R., Nuttall, C. P. and Trueman, E. R. in part. (1969). General features of Bivalvia. In: Moore, R.C. (ed.).
Treatise on Invertebrate Paleontology. Part N. Mollusca 6. Bivalvia. pp. N3-N129. Geological Society of America: Boulder, Colorado. University of Kansas Press: Lawrence, Kansas.

Criscione, F. and Ponder, W.F. (2013). A phylogenetic analysis of rissooidean and cingulopsoidean families (Gastropoda: Caenogastropoda). Molecular Phylogenetics and Evolution 66 (3): 1075-1082.

Dijkstra, H.H. (1991). A contribution to the knowledge of the pectinacean Mollusca (Bivalvia: Propeamussiidae, Entoliidae, Pectinidae) from the Indonesian Archipelago. Zoologische Verhandlingen, Leiden 271 (24): 1-57.

Dijkstra H.H. and Maestrati, P. (2008). New species and new records of deep-water Pectinoidea (Bivalvia: Propeamussiidae, Entoliidae and Pectinidae) from the South Pacific. In: Héros, V., Cowie, R.H. and Bouchet, P. (eds). Tropical Deep-Sea Benthos 25. Mémoires du Muséum national d'Histoire naturelle 196: 77-113.

Fernandes, M.R. and Pimenta, A.D. (2017). Taxonomic overview of Triphoridae in the World: describing triphorids. Sociedade Brasileira de Malacologia Periódico Trimestral, Informativo SBMa, ano 48, 200: 4-10.

Garcia, E.F. (2004). On the genus Cycloscala Dall, 1889 (Gastropoda: Epitoniidae) in the Indo-Pacific, with comments on the type species, new records of known species and the description of three new species. Novapex 5(2-3): 57-68.

Geiger, D.L. (2012). Monograph of the Little Slit Shells. Volumes 1 and 2, Monograph 7. Santa Barbara Museum of Natural History.

Geiger, D.L., Marshall, B.A., Ponder, W.F., Sasaki, T. and Warén, A. (2007). Techniques for collecting, handling and preparing small molluscan specimens. Molluscan Research 27 (Special Issue): 1-50.

Goto, T., Kawakita, A., Ishikawa, H., Hamamura, Y. and Kato, M. (2012). Molecular phylogeny of the bivalve superfamily Galeommatoidea (Heterodonta, Veneroida) reveals dynamic evolution of symbiotic lifestyle and interphylum host switching. BMC Evolutionary Biology 12: 172. doi: 10.1186/1471-2148$12-172$.

Hayami, I. and Kase, T. (1993). Submarine cave bivalvia from the Ryukyu Islands: systematics and evolutionary significance. The University Museum, The University of Tokyo, Bulletin 35: 1-133.

Hedley, C. (1918). Narrative of an expedition of exploration in North Western Australia by Herbert Basedow. Special Report, Mollusca. Transactions of the Royal Geographical Society of Australasia, South Australian Branch 18: 263-283.

Houbrick, R.S. (1987). Anatomy of Alaba and Litiopa (Prosobranchia: Litiopidae): Systematic implications. Nautilus 101: 9-18.

Huber, M. (2010). Compendium of Bivalves. Conchbooks, Hackenheim, Germany.

Huber, M. (2015). Compendium of Bivalves 2. Conchbooks, Hackenheim, Germany.

Iredale, T. and Laseron, C.F. (1957). The systematic status of Ctiloceras and some comparative genera. Proceedings of the Royal Zoological Society of New South Wales 195556. pp. 97-109. 
Jensen, K.R. (1993). Sacoglossa (Mollusca Opisthobranchia) from Rottnest Island and central Western Australia. pp. 207-253 In: Wells, F.E., Walker, D.I., Kirkman, H. and Lethbridge, R. (eds). Proceedings of the Fifth International Marine Biological Workshop: The Marine Flora and Fauna of Albany, Western Australia, Perth, volume 1. Western Australian Museum.

Jensen, K. (1997). Sacoglossa (Mollusca, Ophisthobranchia) from the Darwin Harbour area, Northern Territory, Australia. In: Hanley, J.R., Caswell, G., Megirian, D. and Larson, H.K. (eds). Proceedings of the Six International Marine Biological Workshop. The marine flora and fauna of Darwin Harbour, Northern Territory, Australia. Museums and Art Galleries of the Northern Territory and the Australian Marine Sciences Association: Darwin, Australia. pp. 163-186.

Kirkendale, L., Hosie, A.M. and Richards, Z. (2019). Defining biodiversity gaps for North West Shelf marine invertebrates. Journal of the Royal Society of Western Australia 102: 1-9.

Lamprell, K.L. and Healy, J.M. (1998). A revision of the Scaphopoda from Australian waters (Mollusca). Records of the Australian Museum Supplement 24: $1-189$.

Laseron, C. (1953). Minute bivalves from New South Wales. Records of the Australian Museum 23(2): 33-54.

Laseron, C. (1954). Revision of the Liotiidae of New South Wales. The Australian Zoologist 12(1): 1-25.

Laseron, C. (1956a). The Family Cerithiopsidae (Mollusca) from the Solanderian and Dampierian Zoogeographical Provinces. Australian Journal of Marine and Freshwater Research 7(1): 151-182.

Laseron, C. (1956b). The families Rissoinidae and Rissoidae (Mollusca) from the Solanderian and Damperian zoogeographical provinces. Australian Journal of Marine and Freshwater Research 7(3): 384-484.

Laseron, C. (1957). A new classification of the Australian Marginellidae (Mollusca), with a review of species from the Solanderian and Dampierian Zoogeographical Provinces. Australian Journal of Marine and Freshwater Research 8(3): 274-311.

Laseron, C. (1958a). The Family Triphoridae (Mollusca) from northern Australia, also Triphoridae from Christmas Island (Indian Ocean). Australian Journal of Marine and Freshwater Research 9(4): 569-658.

Laseron, C. (1958b). Liotiidae and allied molluscs from the Dampierian Zoogeographical Province. Records of the Australian Museum 24(11): 165-182.

Laseron, C. (1959). The family Pyramidellidae (Mollusca) from northern Australia. Australian Journal of Marine and Freshwater Research 10: 177-267.

Layton, K.S.K., Middelfart, P.U., Tatarnic, N.J. and Wilson, N.G. (2019). Erecting a new family for Spirostyliferina, a truncatelloidean microgastropod, and further insights into truncatelloidean phylogeny. Zoologica Scripta 48(6): 727-744.

Li, J., Ó Foighil, D. and Middelfart, P. (2012). The evolutionary ecology of biotic association in a megadiverse bivalve superfamily: sponsorship required for permanent residency in sediment. PloS one 7. e42121. doi: 10.1371/journal.pone.0042121.
Lima, S.F.B., Barros, J.C.N., Francisco, J.A. and Oliveira, P.S. (2011). New records of Caribbean Gastropods (Skeneidae, Tornidae, Orbitestellidae and Omalogyridae) for Saint Peter and Saint Paul Archipelago (Brazil). Tropical Zoology 24: 87-106.

Mann, K.H. 1982. Ecology of coastal waters: a systems approach. University of California Press.

Marshall, B. A., (1983). A revision of the recent Triphoridae of southern Australia (Mollusca: Gastropoda). Records of the Australian Museum, Supplement 2: 1-119.

Marshall, B.A. (1988). Skeneidae, Vitrinellidae and Orbitestellidae (Mollusca: Gastropoda) associated with biogenic substrata from bathyal depths off New Zealand and New South Wales. Journal of Natural History 22: 949-1004.

Melvill, J.C. and Standen R. (1896). Notes on a collection of shells from Lifu and Uvea, Loyalty Islands, formed by the Rev. James and Mrs. Hadfield, with list of species. Part II. Journal of Conchology 8: 273315, pls 9-11.

Middelfart, P.U. (2002a). Revision of the Australian Cuninae sensu lato (Bivalvia: Carditoidea: Condylocardiidae). Zootaxa 112: 1-124.

Middelfart, P. (2002b). A revision of the Australian Condylocardiinae (Bivalvia: Carditoidea: Condylocardiidae). Molluscan Research 22: 23-85.

Middelfart, P.U., Kirkendale, L.A. and Wilson, N.G. (2016). Australian tropical marine micromolluscs: An overwhelming bias. Diversity 8(3), [17]. doi: 10.3390/ d8030017.

Morton, B. (1988). Partnerships in the sea: Hong Kong's marine symbioses. Hong Kong University Press. Hong Kong.

Muus, B.J. (1967). The fauna of Danish estuaries and lagoons. Distribution and ecology of dominating species in the shallow reaches of the mesohaline zone. Meddelelser fra Danmarks Fiskeri og Havundersøgelser ns. 5 (1): 1-316.

Ockelmann, K.W. and Muus, K. (1978). The biology, ecology and behaviour of the bivalve Mysella bidentata (Montagu). Ophelia 17:1-93.

Oliver, P.G. and Holmes, A.M. (2004). Cryptic bivalves with descriptions of new species from the Rodrigues lagoon. Journal of Natural History 38 (23/24): 31753227.

Okutani, T. (2000). Marine Mollusks in Japan. Tokai University Press, Japan.

Okutani, T. (2017). Marine Mollusks in Japan. 2nd edition. Tokai University Press, Japan.

OZCAM (Online Zoological Collections of Australian Museums). https:/ /ozcam.org.au/index.html

Peñas A. and Rolán E. (2017). Deep water Pyramidelloidea from the central and South Pacific. The tribe Chrysallidini. ECIMAT (Estación de Ciencias Mariñas de Toralla), Universidade de Vigo.

Pizzini, M., Raines, B., Vannozzi, A. (2013). The family Caecidae in the south-west Pacific (Gastropoda: Rissooidea). Bollettino Malacologico. 49(10): 1-78.

Ponder, W.F. (1983). Review of the genera of the Barleeidae. Records of the Australian Museum 35: 231-281. 
Ponder, W.F. (1985). A review of the genera of the Rissoidae (Mollusca: Mesogastropoda: Rissoacea). Records of the Australian Museum Supplement 4: $1-221$.

Ponder, W.F. (1990). The anatomy and relationships of the Orbitestellidae (Gastropoda: Heterobranchia). Journal of Molluscan Studies 56: 515-532.

Ponder, W.F. (1999). Calopia (Calopiidae), a new genus and family of estuarine gastropods (Caenogastropoda: Rissooidea) from Australia. Molluscan Research 20(1): 17-60. doi: 10.1080/13235818.1999.10673722.

Ponder, W.F. and de Keyzer, R. (1992). A revision of the genus Diala (Gastropoda: Cerithioidea: Dialidae). Invertebrate Taxonomy 6: 1019-1075.

Ponder, W.F. and Yoo, E.K. (1977). A revision of the Australian species of the Rissoellidae (Mollusca: Gastropoda). Records of the Australian Museum 31(4): 133-185.

Ponder, W.F. and. Yoo, E.K. (1978). A Revision of the Eatoniellidae of Australia (Mollusca, Gastropoda, Littorinacea). Records of the Australian Museum 31(15): 606-658.

Ponder, W.F., and Yoo, E.K. (1981). A review of the genera of the Cingulopsidae with a revision of the Australian and tropical Indo-Pacific species (Mollusca: Gastropoda: Prosobranchia). Records of the Australian Museum 33(1): 1-88.

Renard, J. le and Bouchet, P. (2003). New species and genera of the family Pickworthiidae (Mollusca, Caenogastropoda). Zoosystema 25(4): 569-591.

Richards, Z., Bryce, M. and Bryce, C. (2018). The composition and structure of shallow benthic reef communities in the Kimberley, north-west Australia. Records of the Western Australian Museum Supplement 85: 75-103. doi: 10.18195/issn.0313-122x.85.2018.075-103.

Rubio F., Rolán E. and Redfern C. 1998. The genus Lodderena Iredale, 1924 (Archaeogastropoda, Skeneidae) in the Caribbean. Argonauta 11: 39-48.

Rubio F. and Rolán E. (2015). The genus Lophocochlias Pilsbry, 1921 (Gastropoda, Tornidae) in the Indo-West Pacific. Novapex 16(4): 105-120.

Sampey, A., Bryce, C., Osborne, S. and Miles A. (2014). Kimberley marine biota. Historical data: introduction and methods. Records of the Western Australian Museum, Supplement 84: 19-43. doi: 10.18195/issn.0313122x.84.2014.019-043.

Sartori, A. F. and Bieler, R. (2014). Three new species of Ammonicera from the eastern Pacific coast of North America, with redescriptions and comments on other species of Omalogyridae (Gastropoda, Heterobranchia). Zootaxa 3872(1): 1-21.

Tevesz, M.J. (1977). Taxonomy and ecology of the Philobryidae and Limopsidae (Mollusca: Pelecypoda). Postilla 171: 1-65.
Thiele, J. (1930). Die Fauna Südwest-Australiens; Ergebnisse der Hamburger Südwest-australischen Forschungsreise 1905. In: Gastropoda und Bivalvia. Vol. 5.

Warén, A. (1980a). Descriptions of new taxa of Eulimidae (Mollusca, Prosobranchia), with notes on some previously described genera. Zoologica Scripta 9: 283-306.

Warén, A. (1980b). Revision of the genera Thyca, Stilifer, Scalenostoma, Mucronalia and Echineulima (Mollusca, Prosobranchia, Eulimidae). Zoologica Scripta 9: 187-210

Warén, A. (1981). Revision of the genera Apicalia A. Adams and Stilapex Iredale and description of two new genera (Mollusca, Prosobranchia, Eulimidae). Zoologica Scripta 10: 133-154.

Warén, A. (1983). An anatomical description of Eulima bilineata Alder with remarks on and a revision of Pyramidelloides Nevill (Mollusca, Prosobranchia, Eulimidae). Zoologica Scripta 12: 273-294.

Warén, A. (1984). A generic revision of the family Eulimidae (Gastropoda, Prosobranchia). Journal of Molluscan Studies Supplement 13: 1-96.

Warén, A. (2013). Murchisonellidae: who are they, where are they and what are they doing? (Gastropoda, lowermost Heterobranchia). Vita Malacologica 11: $1-14$.

Warén, A., and Crossland, M. R. (1991). Revision of Hypermastus Pilsbry, 1899 and Turveria Berry, 1956 (Gastropoda: Prosobranchia: Eulimidae), two genera parasitic on sand dollars. Records of the Australian Museum 43: 85-112.

Weil, A., Brown, L. and Neville, B. (1999). The Wentletrap Book (Guide to the Recent Epitoniidae of the world). Evolver slr, Rome, Italy.

Wells, F.E. and Allen, G.R. (2005). Marine biodiversity on offshore coral reefs in north-western Australia. The Beagle, Records of the Museum and Art Gallery of the Northern Territory 2005, Supplement 1: 43-50.

Willan, R.C. (2005). The molluscan fauna from the emergent reefs of the northernmost Sahul Shelf, Timor Sea - Ashmore, Cartier and Hibernia Reefs; biodiversity and zoogeography. The Beagle, Records of the Museum and Art Gallery of the Northern Territory 2005, Supplement 1: 51-81.

Willan, R.C., Bryce, C. and Slack-Smith, S.M. (2015). Kimberley marine biota. Historical data: molluscs. Records of the Western Australian Museum. Supplement 84: 287-343. doi: 10.18195/issn.0313122x.84.2015.287-343

Wilson, B.R. (2014). Kimberley marine biota. History and environment. Records of the Western Australian Museum Supplement 84: 1-18. doi: 10.18195/ issn.0313-122x.84.2014.001-018

WoRMS Editorial Board (2018). World Register of Marine Species. Available from http://www. marinespecies.org at VLIZ [accessed 2018-03-26]. doi: $10.14284 / 170$ 